\title{
Li-rich layered oxides: still a challenge, but a very promising positive electrode material for $\mathrm{Li}$-ion batteries
}

\author{
Ségolène Pajot ${ }^{1,2,3}$, Loïc Simonin ${ }^{3}$ and Laurence Croguennec ${ }^{1,4,5, *}$ \\ ${ }^{1}$ CNRS, Univ. Bordeaux, Bordeaux INP, ICMCB UPR 9048, F-33600 Pessac, France \\ ${ }^{2}$ CEATech Aquitaine, 16 avenue Pey Berland - 33607 Pessac - France \\ ${ }^{3}$ Univ. Grenoble Alpes, F-38000 Grenoble, CEA, LITEN, 17 rue des Martyrs, \\ F-38054 Grenoble cedex 9, France \\ ${ }^{4}$ RS2E, Réseau Français sur le Stockage Electrochimique de l'Energie, FR CNRS 3459, \\ F-80039 Amiens Cedex 1, France \\ ${ }^{5}$ ALISTORE-ERI European Research Institute, FR CNRS 3104, F-80039 Amiens Cedex 1, France
}




\section{Table of Contents}

$\begin{array}{lll}\text { I. Introduction } & \text { p. } 4\end{array}$

$\begin{array}{ll}\text { II. The state of the art } & \text { p. } 4\end{array}$

$\begin{array}{ll}\text { III. The layered oxides } \mathrm{Li}_{1+\mathrm{x}} \mathrm{M}_{1-\mathrm{x}} \mathrm{O}_{2} \text { rich in lithium } & \text { p. } 8\end{array}$

A. The intriguing performance of the Lithium and Manganese-rich layered oxides at $\begin{array}{ll}\text { the center of ten years of challenging researches } & \text { p. } 8\end{array}$

$\begin{array}{lll}\text { 1. From the average structure to the local structure } & \text { p. } 8\end{array}$

2. The overcapacity: its origin and impacts p. 11

3. Direct characterization of the oxidized oxygen species p. 17

$\begin{array}{ll}\text { 4. Perspectives for reversible redox on oxygen ions } & \text { p. } 20\end{array}$

B. The Lithium and Manganese rich layered oxides as composite materials p. 21

$\begin{array}{ll}\text { 1. The benefit of blends and of coatings } & \text { p. } 22\end{array}$

$\begin{array}{ll}\text { 2. The concentration gradients } & \text { p. } 24\end{array}$

$\begin{array}{ll}\text { a). Their synthesis by coprecipitation } & \text { p. } 25\end{array}$

b). The attractive properties of the concentration gradients $\quad$ p. 29

$\begin{array}{ll}\text { IV. Conclusions p. } 34 & \text { p }\end{array}$

$\begin{array}{ll}\text { References } & \text { p. } 35\end{array}$ 


\section{List of Abbreviations}

2D

ALD

CVD

DEMS

DFT

DSC

EDX

EELS

EPMA

EPR

FCG

HAADF

LCO

MAS

NCA

NMC

NMR

PLD

RIXS

SEM

STEM

SXAS

XAS

XPS
Bi-dimensional

Atomic Layer Deposition

Chemical Vapor Deposition

Differential Electrochemical Mass Spectrometry

Density Functional Theory

Differential Scanning Calorimetry

Energy Dispersive X-Ray spectroscopy

Electron Energy Loss Spectroscopy

Electron Probe X-ray Micro Analysis

Electron Paramagnetic Resonance

Full Concentration Gradient

High Angular Annular Dark Field

$\mathrm{LiCoO}_{2}$

Magic Angle Spinning

$\mathrm{LiNi}_{1-\mathrm{x}-\mathrm{y}} \mathrm{Co}_{\mathrm{x}} \mathrm{Al}_{\mathrm{y}} \mathrm{O}_{2}$

$\mathrm{LiNi}_{1-\mathrm{x}-\mathrm{y}} \mathrm{Mn}_{\mathrm{x}} \mathrm{Co}_{\mathrm{y}} \mathrm{O}_{2}$

Nuclear Magnetic Resonance spectroscopy

Pulsed Laser Deposition

Resonant Inelastic X-ray Scattering spectroscopy

Scanning Electron Microscopy

Scanning Transmission Electron Microscopy

Soft X-ray Absorption Spectroscopy

X-ray Absorption Spectroscopy

X-ray Photoelectron Spectroscopy 


\section{Introduction}

Lithium-ion batteries entered the market in the 1990's, they have made possible the development of the electronic market with the emergence of a large panel of applications such as portable electronics and power tools, increasingly more and more demanding in energy and power, but also in weight and volume restrictions. Lithium-ion batteries are still at the center of researches to challenge recent concerns: transportation with different degrees of electrification, large scale stationary storage of renewable energies produced by wind and solar farms, and improvement of the grid reliability and stability in helping to compensate for imperfections due to energy mix. All these new applications and demands are pushing further the development of the Li-ion technology and its market. Indeed, even if considered as mature, improvements are still possible: in this chapter devoted to layered oxides, currently at the positive electrodes in most of the commercial Lithium-ion batteries, we will discuss the possible tracks to follow to increase further their energy, stability, etc. Early Lithium-ion batteries consisted of the layered oxide $\mathrm{LiCoO}_{2}$ at the positive electrode and of graphite at the negative electrode. After more than 25 years of development, the chemistries used remain similar but, for instance, on the positive electrode side the spectrum of the layered oxides used has widened to fit the set of requirements depending on the applications targeted, with the development of complex compositions, blends, composites with surface or even bulk engineering. 


\section{The state of the art}

The layered oxides $\mathrm{LiMO}_{2}$ are electrochemically active with reactions revealed to be mainly topotactic, i.e. occurring without any major volume change and irreversibility in the host structure. The oxidation/reduction processes involve the exchange of electrons coupled to reversible lithium de-insertion/insertion reactions. For most of the layered oxides, their theoretical electrochemical capacity is limited to one electron per transition metal, as only transition metal cations are involved in the redox processes. These layered oxides' structural frameworks are bi-dimensional (2D) with the alternated stacking of $\mathrm{MO}_{2}$ slabs and $\mathrm{LiO}_{2}$ interslab spaces made up respectively of edge-sharing $\mathrm{MO}_{6}$ and $\mathrm{LiO}_{6}$ octahedra. These interslab spaces are the 2D diffusion pathways for lithium ions in the structure, by jumping from one octahedron to another through intermediate face-sharing tetrahedral sites. [1] Playing with the composition of $\mathrm{LiMO}_{2}(\mathrm{M}=\mathrm{Co}, \mathrm{Ni}, \mathrm{Mn}, \mathrm{Al} \ldots)$, its structural, physicochemical and electrochemical properties can be tailored. Simple or more complex compositions are already on the market, for years for some of them: $\mathrm{LiCoO}_{2}$ (LCO), $\mathrm{LiNi}_{0.80} \mathrm{Co}_{0.15} \mathrm{Al}_{0.05} \mathrm{O}_{2}$ (NCA), $\mathrm{LiNi}_{1 / 3} \mathrm{Co}_{1 / 3} \mathrm{Mn}_{1 / 3} \mathrm{O}_{2}$ (NMC) ... Each of these compositions is chosen for a given application taking always into account the requirements in cost, safety, energy, power and cyclability.

As often, the defect chemistry plays a major role on the structure, but also on the properties, of these layered oxides. Most $\mathrm{LiCoO}_{2}$ materials used in commercial lithium-ion batteries were shown to be in fact over-stoichiometric $\mathrm{Li}_{1+\mathrm{x}} \mathrm{Co}_{1-\mathrm{x}} \mathrm{O}_{2-\mathrm{x}}$ (with $\mathrm{Li} / \mathrm{Co}>1$ and $\mathrm{x}>0$ ) as large scale industrial syntheses are performed using an excess of the lithium carbonate precursor [2] : (i) to promote the particles' growth for a better chemical stability and a minimized solidliquid interface with the electrolyte, and (ii) to prevent the formation of the impurity $\mathrm{Co}_{3} \mathrm{O}_{4}$ which is detrimental to the performances. The introduction of these defects in the structure, trivalent cobalt ions in square-based pyramids with an original electronic configuration $\mathrm{t}_{2 \mathrm{~g}}{ }^{5} \mathrm{e}_{\mathrm{g}}{ }^{1}$, allows suppressing all the phase transitions associated to $\mathrm{Li}^{+} /$vacancy ordering in $\mathrm{LiCoO}_{2}$, and thus increasing its ionic and electronic transport properties for better performances at high rates.

Researches are still very active on $\mathrm{LiCoO}_{2}$ with the goal to stabilize reversibly the structure of the highly deintercalated $\mathrm{Li}_{\mathrm{x}} \mathrm{CoO}_{2}$ compositions $(\mathrm{x}<0.5)$ at high voltage and thus to develop high energy $\mathrm{LiCoO}_{2}$ based materials, maintaining - or even increasing - their thermal stability in the charge state of the batteries as well as their rate capabilities. Indeed, $\mathrm{LiCoO}_{2}$ is the 
material of choice at the positive electrode of batteries developed for mobile applications, but even in that field energy demands are increasing with the development of new applications such as electronic tablets for instance. Combining complex and complementary strategies, significant optimization has already been achieved. [3] These material engineering approaches can be: (i) the bulk modification of the active material through a partial substitution for cobalt (Al [4], Mg [5], ...) (ii) the surface modification through the formation of inorganic [6] or polymeric "coatings", being often for the former nanoparticles decorating the surface and the grain boundaries, and (iii) a surface treatment of the electrode using deposition techniques as described in Figure 1 [7]. Partial substitution of the bulk is often combined with surface modifications, either through a further doping of the extreme surface (being thus electrochemically active) or through the formation of a stabilizing interface (allowing lithium diffusion but being not electrochemically active itself).

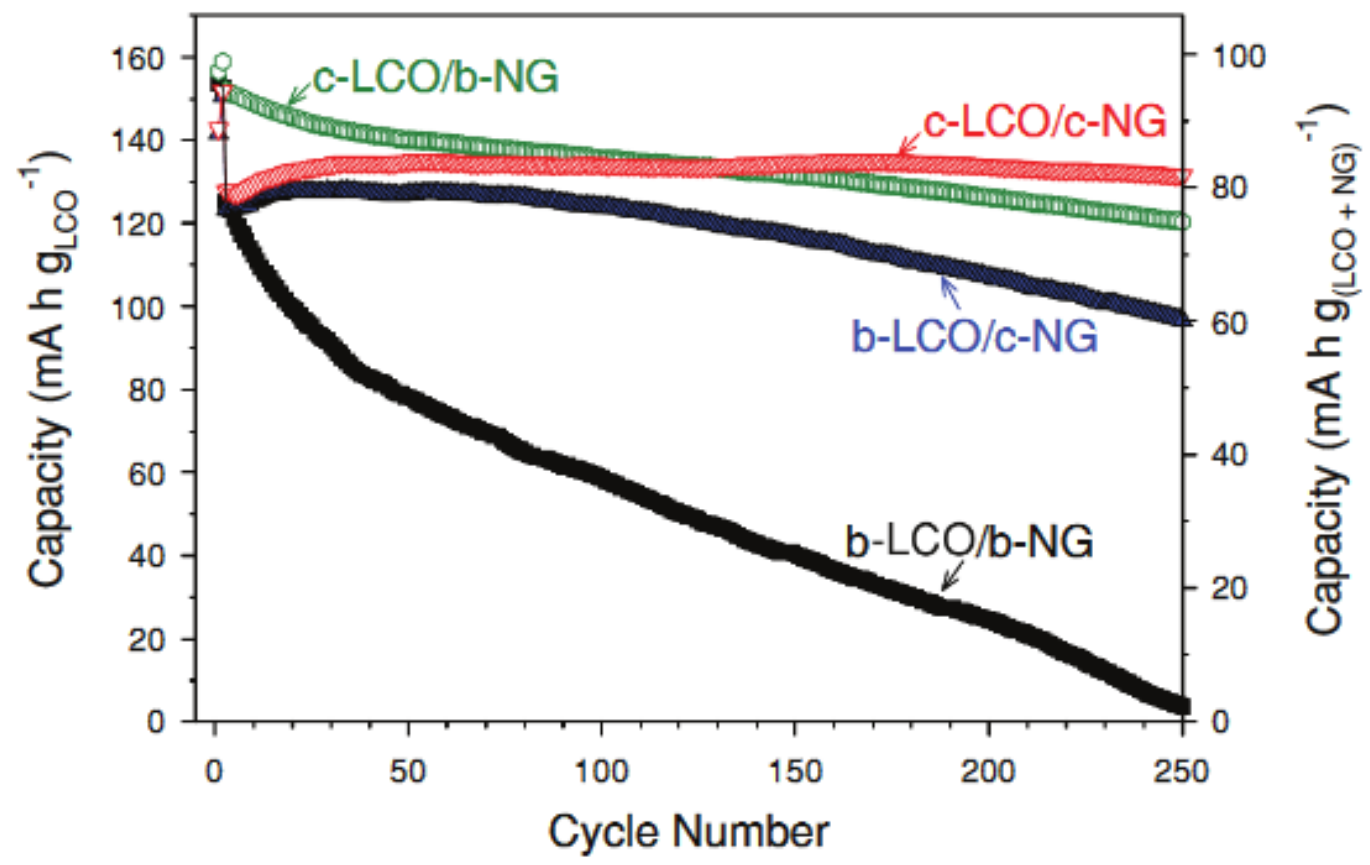

Figure 1: Comparison of the electrochemical performances of $\mathrm{LiCoO}_{2} /$ graphite full cells with bare (i.e. uncoated) electrodes (named as b-) or with coated electrodes (named as c-). The $\mathrm{Al}_{2} \mathrm{O}_{3}$ coating was performed using Atomic Layer Deposition (ALD). [Reproduced with permission from [7]] 
The optimized compositions $\mathrm{LiNi}_{0.80} \mathrm{Co}_{0.15} \mathrm{Al}_{0.05} \mathrm{O}_{2}(\mathrm{NCA})$ and $\mathrm{LiNi}_{1 / 3} \mathrm{Co}_{1 / 3} \mathrm{Mn}_{1 / 3} \mathrm{O}_{2}(\mathrm{NMC}$ or (333) hereafter) remain expensive due to the cost of both nickel and cobalt, NCA being the more attractive for high rate applications [8]. Indeed, electron hopping among the nickel ions $\left(\mathrm{Ni}^{3+, 4+}\right)$ within the $\mathrm{MO}_{2}$ slabs promotes faster lithium diffusion within the structure, whereas ordering of the $\mathrm{Ni}, \mathrm{Mn}$ and $\mathrm{Co}$ ions in NMC is detrimental to electron mobility and thus to ionic conductivity. These compositions were developed using the solid state chemist's background to track the better substitutions for optimized performances. [9] Partial substitution of nickel for cobalt in $\mathrm{LiCoO}_{2}$ has been first considered in order to decrease its cost, revealing that $\mathrm{LiNi}^{\mathrm{III}}{ }_{0.7} \mathrm{Co}^{\mathrm{III}}{ }_{0.3} \mathrm{O}_{2}$ was in fact the optimized composition versus the end members $\mathrm{LiCo}^{\mathrm{III}} \mathrm{O}_{2}$ and $\mathrm{LiNi}^{\mathrm{III}} \mathrm{O}_{2}$, due to the difficulty to control the stoichiometry of the pure nickelate, most often stabilized as $\mathrm{Li}_{1-\mathrm{z}} \mathrm{Ni}_{1+\mathrm{z}} \mathrm{O}_{2}$ with an excess of $\mathrm{Ni}^{2+}$ ions in the lithium sites that deteriorate drastically the performances [10]. In fact, the combined partial substitution of cobalt and aluminum for nickel was revealed to be the key to control both the $2 \mathrm{D}$ character of the structure and the thermal stability of the active material in the charged state of the battery [11]. First, the small size of $\mathrm{Co}^{3+}$ and $\mathrm{Al}^{3+}$ tailors the crystal field such as to destabilize the formation of $\mathrm{Ni}^{2+}$ in the slabs and, as a consequence, in the interslab space. Second, the partial substitution by the electrochemically inactive cation $\mathrm{Al}^{3+}$ allows decreasing the amount of unstable $\mathrm{Ni}^{4+}$ (and/or $\mathrm{Co}^{4+}$ ) cations formed at the end of the charge (promoting a better thermal stability) and preventing overcharge as the reversible capacity delivered is intrinsically limited by the restricted number of electrons that can be exchanged on the metals. Third, the stabilization of $\mathrm{Al}^{3+}$ in the intermediate tetrahedral sites upon increasing temperature allows to increase the stability of the highly delithiated compositions, as they delay all the phase transitions associated to oxygen loss and to the irreversible formation of spinels. The emergence of the ternary layered compounds $\mathrm{Li}\left(\mathrm{Ni}_{\mathrm{x}} \mathrm{Mn}_{1-\mathrm{x}-\mathrm{y}} \mathrm{Co}_{\mathrm{y}}\right) \mathrm{O}_{2}$ found its origin considering first the system $\mathrm{Li}\left[\mathrm{Li}_{0.2} \mathrm{Mn}^{\mathrm{IV}}{ }_{0.4} \mathrm{Cr}^{\mathrm{III}}{ }_{0.4}\right] \mathrm{O}_{2}$ by bringing the redox couple $\mathrm{Cr}^{6+} / \mathrm{Cr}^{3+}$ into play with the manganese remaining tetravalent. [12] This system displays a multielectron redox center (chromium) responsible for the capacity beside the $\mathrm{Mn}^{4+}$ ions, which are inactive during the redox processes and act as stabilizers for the host network. These results have paved the way for the development of a new family of layered transition metal oxides as alternatives to $\mathrm{LiCoO}_{2}$ and $\mathrm{Li}\left(\mathrm{Ni}_{1-\mathrm{y}-\mathrm{z}} \mathrm{Co}_{\mathrm{y}} \mathrm{Al}_{\mathrm{z}}\right) \mathrm{O}_{2}$ at the positive electrode of lithium-ion batteries and led to reconsider the early work on the $\mathrm{LiNi}_{1-\mathrm{y}} \mathrm{Mn}_{\mathrm{y}} \mathrm{O}_{2}$ system. [13] Rapidly, $\mathrm{LiNi}{ }_{1 / 2}^{\mathrm{II}} \mathrm{Mn}^{\mathrm{IV}}{ }_{1 / 2} \mathrm{O}_{2}$ and $\mathrm{LiNi}^{\mathrm{II}}{ }_{1 / 3} \mathrm{Mn}^{\mathrm{IV}}{ }_{1 / 3} \mathrm{Co}^{\mathrm{III}}{ }_{1 / 3} \mathrm{O}_{2}$ were proposed. [14], [15] The goal was here to combine high reversible capacity playing with the redox couples $\mathrm{Ni}^{2+} / \mathrm{Ni}^{3+} / \mathrm{Ni}^{4+}$ (exchange of 2 electrons per $\mathrm{Ni}$ ) and $\mathrm{Co}^{3+} / \mathrm{Co}^{4+}$, coulombic efficiency thanks to a controlled 2D layered 
dimensionality for the structure, and a high thermal stability in the charged state due to a large fraction of stable transition metal ions as $\mathrm{Mn}^{4+}$. As mentioned already, the main drawback of these manganese-rich compositions is their limited transport properties. Even more complex compositions $\mathrm{Li}\left(\mathrm{Ni}_{1-2 \mathrm{x}-\mathrm{y}}^{\mathrm{III}} \mathrm{Ni}_{\mathrm{x}}^{\mathrm{II}} \mathrm{Mn}^{\mathrm{IV}}{ }_{\mathrm{x}} \mathrm{Co}_{\mathrm{y}}\right) \mathrm{O}_{2}$ were considered in order to combine a mixed valence $\left(\mathrm{Ni}^{2+, 3+}\right)$ for a partial electronic delocalization on the nickel network and a significant content in manganese for an improved structural and thermal stability. Changes in the performances with the content in $\mathrm{Ni}, \mathrm{Co}$ and $\mathrm{Mn}$ are significant as summarized in Figure 2, and the composition $\mathrm{LiNi}_{0.6} \mathrm{Mn}_{0.2} \mathrm{Co}_{0.2} \mathrm{O}_{2}$ (called 622) appears today as the best compromise.[16]

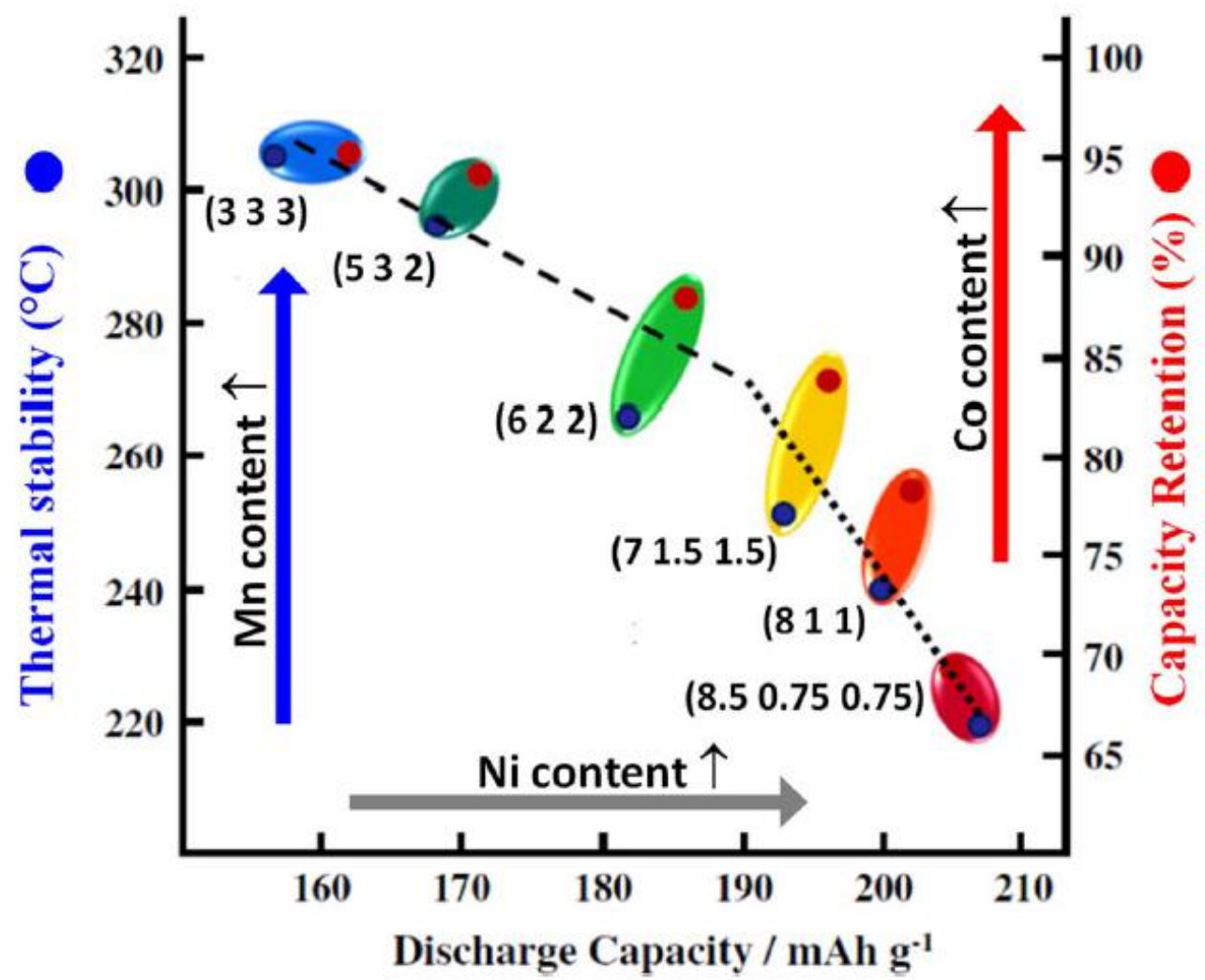

Figure 2: Changes in the discharge reversible capacity (in black), thermal stability in the charged state of the battery (in blue) and capacity retention upon long range cycling (in red) for layered oxides of compositions $\mathrm{Li}\left(\mathrm{Ni}_{\mathrm{x}} \mathrm{Mn}_{1-\mathrm{x}-\mathrm{y}} \mathrm{Co}_{\mathrm{y}}\right) \mathrm{O}_{2}$ with the content in $\mathrm{Ni}, \mathrm{Mn}$ and $\mathrm{Co}$ given into brackets (adapted from the reference [17]). 


\section{The layered oxides $\mathrm{Li}_{1+\mathrm{x}} \mathrm{M}_{1-\mathrm{x}} \mathrm{O}_{2}$ rich in lithium}

In parallel, other layered oxides rich in $\mathrm{Li}$ and in $\mathrm{Mn}$ of general chemical formulae $\mathrm{Li}_{1+\mathrm{x}} \mathrm{M}_{1-}$ ${ }_{\mathrm{x}} \mathrm{O}_{2}$ were also at the center of challenging researches in the field, as they could deliver, if stabilized, significantly increased energy density with the involvement of the anion in the redox processes.

\section{A. The intriguing performance of the Lithium and Manganese-rich layered oxides at the center of ten years of challenging researches}

\section{From the average structure to the local structure}

The structure of the compositions $\mathrm{Li}_{1+\mathrm{x}} \mathrm{M}_{1-\mathrm{x}} \mathrm{O}_{2}$ rich in lithium, also called the overlithiated layered oxides or the $\mathrm{Li}$-rich, derives from those of $\alpha-\mathrm{NaFeO}_{2}$ and $\mathrm{LiMO}_{2}$ with a substitution of $\mathrm{Li}$ for $\mathrm{M}$ in the slabs $\mathrm{MO}_{2}$ (Figure 3). The charge compensation is achieved through the increase in the average oxidation state of the transition metal $\mathrm{M}$ such as $\mathrm{Li}\left(\mathrm{Li}^{+}{ }_{\mathrm{x}} \mathrm{M}^{3+}{ }_{1-}\right.$ $\left.{ }_{3 \mathrm{x}} \mathrm{M}^{4+}{ }_{2 \mathrm{x}}\right) \mathrm{O}_{2}(\mathrm{x} \leq 1 / 3)$. For $\mathrm{x}=1 / 3 \mathrm{Li}_{2} \mathrm{MnO}_{3}$ is the most studied and shows an ordering between $\mathrm{Mn}^{4+}$ and $\mathrm{Li}^{+}$in the slabs $\left(\mathrm{Li}_{1 / 3} \mathrm{Mn}_{2 / 3}\right) \mathrm{O}_{2}$, at the origin of a monoclinic distortion described in the $\mathrm{C} 2 / \mathrm{m}$ space group. That unit cell corresponds in fact to a $3 a_{\text {hex }} \times 3 a_{\text {hex }}$ superstructure in the hexagonal cell of $\alpha-\mathrm{NaFeO}_{2}$. Two octahedral sites are present in the slabs, the $2 b$ site is occupied by Lithium whereas the $4 \mathrm{~g}$ site is occupied by Manganese whose sizes are very different (0.74 and $0.54 \AA$ respectively). That intriguing compound was considered as electrochemically inactive as lithium deintercalation could not be compensated by the oxidation of manganese being already in its tetravalent state. The decrease of the particles' size, inducing also an increasing amount of stacking faults in $\mathrm{Li}_{2} \mathrm{MnO}_{3}$ [18], was shown to lead to an activation of its electrochemical activity questioning the possible effects of oxygen non-stoichiometry [19] and the formation of spinel-type domains at the particles' surface [20]. Indeed, the presence of oxygen defects in $\mathrm{Li}_{2} \mathrm{MnO}_{3-\delta}$ induces for charge compensation the partial reduction of manganese $\left(\mathrm{Mn}^{4+}\right.$ into $\left.\mathrm{Mn}^{3+}\right)$, improving the electronic transport properties in the pristine state and thus the electrochemical performances. More recently it was shown that the formation of highly homogeneous composites with conductive carbon allows activating even 


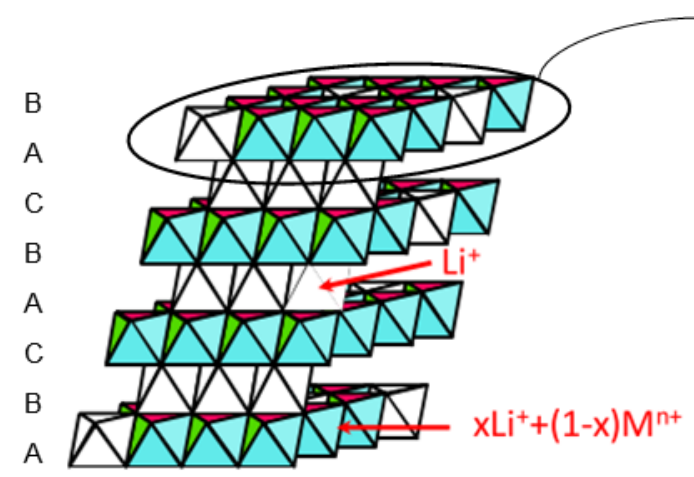

(a)

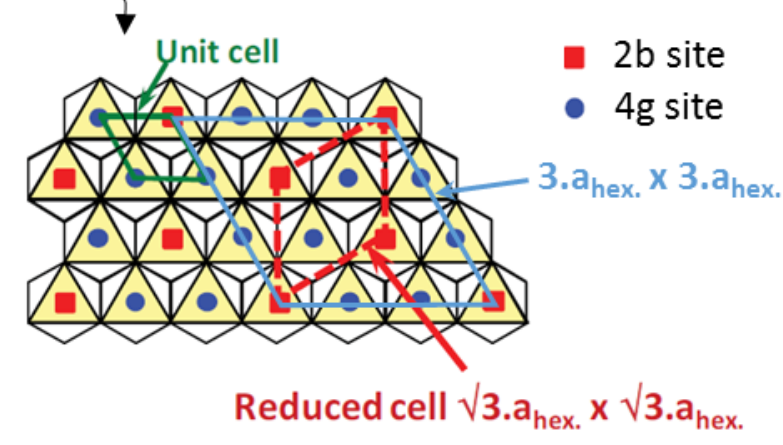

(b)

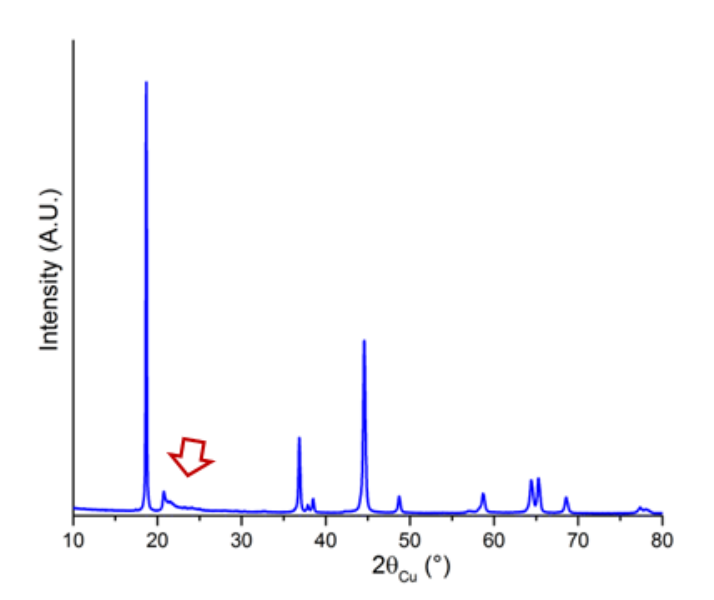

(c)

Figure 3: Structural representation of the Li-rich layered oxides $\mathrm{Li}_{1+\mathrm{x}} \mathrm{M}_{1-\mathrm{x}} \mathrm{O}_{2}$ : (a) the $\mathrm{MO}_{2}$ slabs are occupied by the transition metal ions $\mathrm{M}$ and $\mathrm{Li}$ in excess, whereas the interslab space is only occupied by $\mathrm{Li}$; (b) description of the possible cation distribution within the 2D slabs, with the two sites for cations ( $2 \mathrm{~b}$ and $4 \mathrm{~g}$ in the $C 2 / m$ space group description). The small hexagonal cell (in green) describes the typical layered structure $\mathrm{LiMO}_{2}$ (space group $R-3 m$ ) with a statistical distribution of the cations in a single crystallographic site. The larger unit cells (in blue, and in red for the reduced one) allow describing an order in the slabs as observed for $\mathrm{Li}_{2} \mathrm{MnO}_{3}$. It can be an order between the large and the small cations, here 1:2, to stabilize the structure and to minimize the strains. (c) A typical X-ray diffraction pattern of these Li-rich layered oxides with extra lines in the angular range between 20 and $30^{\circ} 2 \theta$ : the broad lines - as observed here - indicate a tendency to the ordering within the slabs, but without any correlation between the ordered slabs along the stacking axis (Adapted from [17]).

highly crystalline $\mathrm{Li}_{2} \mathrm{MnO}_{3}$ [21]. Lithium deintercalation from $\mathrm{Li}_{2} \mathrm{MnO}_{3}$ was first associated to the removal of $\mathrm{Li}_{2} \mathrm{O}$ [22], and finally revealed to combine lithium deintercalation from the $\mathrm{Li}$ and $\mathrm{Mn}$ sites with $\mathrm{O}_{2}$ gas evolution [23], [24]. Beyond $\mathrm{Li}_{2} \mathrm{MnO}_{3}$, the composition of the slabs of the Li-rich layered oxides $\mathrm{Li}_{1+\mathrm{x}} \mathrm{M}_{1-\mathrm{x}} \mathrm{O}_{2}$ can be tailored considering a large panel of cations next to $\mathrm{Mn}$ and $\mathrm{Li}(\mathrm{Ni}, \mathrm{Co}, \mathrm{Al}, \mathrm{Mg} \ldots$...). Trivalent cobalt and divalent nickel ions are in fact mostly considered as they are electrochemically active and similar in size to $\mathrm{Mn}^{4+}$ and $\mathrm{Li}^{+}$ respectively. Indeed $\mathrm{Ni}^{2+}$ is a large cation $(0.69 \AA)$ and occupies thus preferentially the $2 \mathrm{~b}$ site, whereas $\mathrm{Co}^{3+}$ is smaller $(0.545 \AA)$ and occupies thus the $4 \mathrm{~g}$ site next to Mn. The closer to 
a ratio of 1:2 between large and small cations in the slabs, the more extended is the ordering within the transition metal layers. Nevertheless, due to the complexity of compositions studied, the ordering along the stacking of the layers is barely observed, except for $\mathrm{Li}_{2} \mathrm{MnO}_{3}$, $\mathrm{Li}_{2} \mathrm{RuO}_{3}$, etc. [25]-[27]. Note that as soon as the order is limited (small domain sizes), the structure cannot be described satisfyingly anymore either in the $\mathrm{C} 2 / \mathrm{m}$ space group or in the R$3 \mathrm{~m}$ space group: the first being associated to the fully cationic ordered structure and the second to the fully statistically cationic distributed structure (or to the average structure). The key signature for these structural differences is brought by the additional peaks observed between $20^{\circ}$ and $30^{\circ}\left(2 \theta_{\mathrm{Cu}}\right)$ in the $\mathrm{X}$-ray diffraction patterns (Figure 3): the higher their intensities, the sharper their width, the more ordered are the cations within the structure as these peaks are associated to the superstructure.

As extensively studied by McCalla et al. for the Li-Mn-Ni-O and Li-Mn-Co-O systems using the combinatorial approach [28]-[31] the material's homogeneity is largely dependent on the synthesis conditions, explaining also all the apparent discrepancies reported on these lithiumrich compounds [32]. They can be described:

- as aggregates with primary particles containing domains of compositions and structures $\mathrm{Li}_{2} \mathrm{Mn}^{\mathrm{IV}} \mathrm{O}_{3}$ and $\mathrm{LiM}^{\mathrm{III}} \mathrm{O}_{2}$, explaining the formula often used (1y) $\mathrm{Li}_{2} \mathrm{MnO}_{3} \cdot \mathrm{yLiMO}_{2}$ to describe them [33].

- as aggregates of primary particles being solid solutions (i.e. homogenous cationic distribution within the material) with a tendency to form an order more or less extended between the $\mathrm{Li}, \mathrm{M}^{\mathrm{n}+}$ and $\mathrm{Mn}^{4+}$ ions within the slabs, the size of the cations controlling this order (as just discussed previously) [34]-[36].

- as a mixture of different phases (layered, spinel and/or rock salt) observed at the scale of the primary particles. [28, 29], [37] The closer to the surface, the more lithium and oxygen deficient are the phases, in good agreement with the presence of spinel and rock-salt-type domains in the last few atomic layers described in the Fd-3m and Fm3m space groups respectively.

All the debates concerning the structure of these Li-rich layered oxides come from the fact that the formula $(1-\mathrm{y}) \mathrm{Li}_{2} \mathrm{MnO}_{3} \cdot \mathrm{yLiMO}_{2}$, that allows describing in a simple way how to tailor the formation of $\mathrm{Li}$ and $\mathrm{Mn}^{4+}$-rich layered oxides from a chemical point of view, was largely interpreted among the community as describing the structure of the material with local domains being either $\mathrm{Li}_{2} \mathrm{MnO}_{3}$ or $\mathrm{LiMO}_{2}$. In fact, $\mathrm{Li}_{2} \mathrm{MnO}_{3}$ domains most often do not exist 
as their extension is limited to the first coordination sphere with the observation of $\mathrm{Li}\left[\mathrm{Mn}_{6}\right]$ and $\mathrm{Mn}\left[\mathrm{Li}_{3} \mathrm{Mn}_{3}\right]$ environments, considering also that often they are even $\mathrm{Li}\left[(\mathrm{Mn}, \mathrm{Co})_{6}\right]$ and $\mathrm{Mn}\left[(\mathrm{Li}, \mathrm{Ni})_{3}(\mathrm{Mn}, \mathrm{Co})_{3}\right]$ for $\mathrm{Li}-\mathrm{Mn}-\mathrm{Ni}-\mathrm{O}$ and $\mathrm{Li}-\mathrm{Mn}-\mathrm{Co}-\mathrm{O}$ systems.

\section{The overcapacity: its origin and impacts}

The layered oxides rich in Lithium and in Manganese are very attractive as they deliver significantly improved high specific capacity and, thanks to $\mathrm{Mn}$, at lower price and for more sustainable compositions. Their theoretical capacity is up to $350 \mathrm{mAh} / \mathrm{g}$ (i.e. a significant overcapacity versus classical layered oxides $\mathrm{LiMO}_{2}$ ) [34]. To reach this very attractive reversible capacity, it is crucial to "activate" these materials by charging the battery to high potential (up to $4.8 \mathrm{~V}$ vs. $\mathrm{Li}^{+} / \mathrm{Li}$ ), near the limit of the electrolyte stability versus oxidation. Then they deliver a reversible capacity up to $230-250 \mathrm{mAh} / \mathrm{g}$ in the potential window $2.5 \mathrm{~V}$ 4.6 $\mathrm{V}$ vs $\mathrm{Li}^{+} / \mathrm{Li}$. This performance is exceptional as shown by comparison with Figure 2 because significantly higher than that observed for stoichiometric layered oxides $\mathrm{LiMO}_{2}(\leq$ $200 \mathrm{mAh} / \mathrm{g}$ due to a severe loss of capacity in a larger cycling potential window), and as involving the participation of the oxygen anion to the redox processes. Indeed, it is associated to lithium deintercalation and re-intercalation reactions partly compensated by the participation of anion to the redox processes. As shown in Figure 4, a long plateau is observed during the first charge, which is not observed for the classical layered oxides $\mathrm{Li}_{1-\mathrm{x}} \mathrm{M}_{1+\mathrm{x}} \mathrm{O}_{2}(\mathrm{x} \leq 1)$. At the beginning of the plateau, all the transition metal ions have reached their upper valence state, here the tetravalent state for $\mathrm{Co}, \mathrm{Ni}$ and $\mathrm{Mn}$. From the discovery of these intriguing materials Dahn and co. [34] had proposed a mechanism for charge compensation based on Lithium deintercalation balanced by oxygen loss as if $\mathrm{Li}_{2} \mathrm{O}$ was formed [22]. 


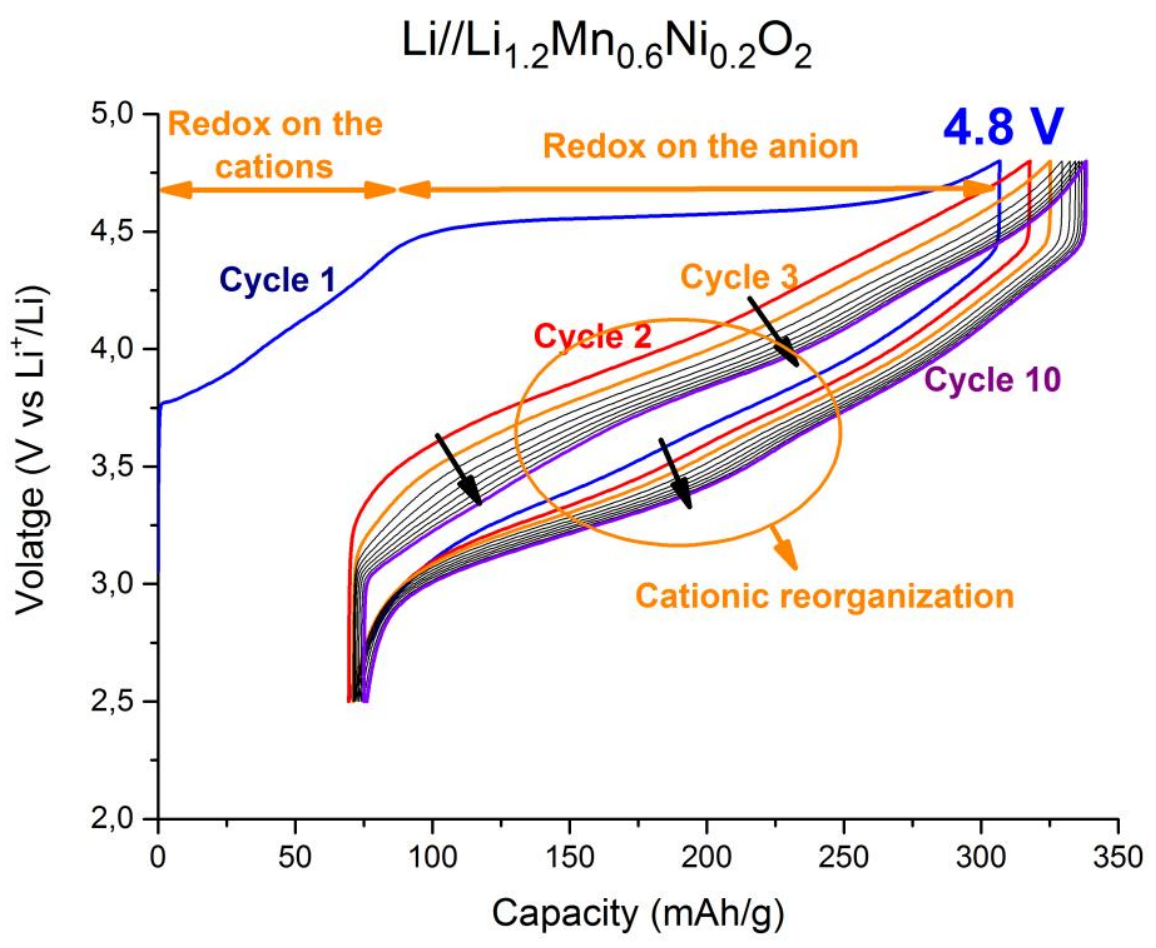

Figure 4: Cycling curves (between the $1^{\text {st }}$ and the $10^{\text {th }}$ cycles) obtained for the lithium batteries $\mathrm{Li} / / \mathrm{Li}_{1.2} \mathrm{Ni}_{0.2} \mathrm{Mn}_{0.6} \mathrm{O}_{2}$ and showing a long irreversible plateau during the first charge at $4.5 \mathrm{~V} \mathrm{vs} \mathrm{Li}^{+} / \mathrm{Li}$.

Very rapidly the mechanism was considered as being more complex as the experimental oxygen loss was revealed to be an order of magnitude smaller than expected to balance the lithium deintercalation reaction [38]. In fact for most of the composition the only compensation of lithium deintercalation by oxygen loss would have meant most of the transition metal ions in $\mathrm{MO}_{5}$ coordination environments and an overall diffusion of oxygen through the solid. This exceptional capacity can in fact be explained by the reversible participation of oxygen to the redox processes within the bulk of the material, without major structural modifications. It was demonstrated by Koga et al. for the composition $\mathrm{Li}_{1.2} \mathrm{Ni}_{0.13} \mathrm{Co}_{0.13} \mathrm{Mn}_{0.54} \mathrm{O}_{2}$ [27], [39]-[41], and directly observed by Oishi et al. for $\mathrm{Li}_{1.2} \mathrm{Ni}_{0.13} \mathrm{Co}_{0.13} \mathrm{Mn}_{0.54} \mathrm{O}_{2}$ using $\mathrm{O}$ K-edge XAS both in the total electron yield mode and in the partial fluorescence X-ray yield mode thus proving the anionic activity even in the bulk [42]. Nevertheless the stability of the oxidized oxygen species at the extreme surface is obviously small, as it was shown that a partial oxygen loss occurs inducing the migration of transition metal ions from the surface to the bulk, a cationic reorganization and a densification of the metal-oxygen framework. [43]-[48] That latter induced the formation of a "splayered-type" phase («mid-way» between a layered structure and a spinel structure). Indeed these migrations and structural modifications occur at room temperature, in metastable conditions 
and the long range spinel structure cannot be obtained in these conditions. All these structural modifications required to be observed and understood the combination of advanced microscopy and spectroscopy techniques such as HAADF-STEM and STEM-EELS.

The reconstruction at the surface of the primary particles has a huge impact on the potential as this one is measured at the surface of the particles and thus driven by the nature of the material present at the surface. The drop in potential induced by the splayered structure makes that the energy density drops with, reducing drastically the performances of that material as energy is the product of the voltage by the reversible capacity. Furthermore, during the next discharge and cycles, to compensate for the oxygen loss, manganese which was inactive during the first charge, enters in the redox processes through its reduction during the first discharge $\left(\mathrm{Mn}^{4+} \rightarrow \mathrm{Mn}^{3+}+1 \mathrm{e}-\right)$. Its activity appears at low voltage, below $3.5 \mathrm{~V} \mathrm{vs.} \mathrm{Li}^{+} / \mathrm{Li}$. As described in Figure 5, it was shown that $\mathrm{Li}^{+}$ions deintercalated at the very end of the charge are only reintercalated at a very low potential upon reduction, with an hysteresis of $1 \mathrm{~V}$, showing that the lithium diffusion pathways are very different between first charge and first discharge: the hysteresis is thus not related to a kinetic limitation but to an intrinsic thermodynamic behavior. [49]-[52] As suggested by neutron powder diffraction and ${ }^{6}$ Li MAS NMR analyses of de-intercalated and re-intercalated compositions recovered after cycling, manganese ions would migrate in tetrahedral sites in the Li layer at high voltage $(>4.1 \mathrm{~V}$ vs. $\left.\mathrm{Li}^{+} / \mathrm{Li}\right)$ and would be destabilized during the next discharge only at low voltage $(<3.2 \mathrm{~V}$ vs. $\mathrm{Li}^{+} / \mathrm{Li}$ ) for highly lithiated compositions. [53], [54] These manganese ions are mobile as in the vicinity of oxygen vacancies or in very distorted environments formed by the shortening of $\mathrm{O}$ O distances thanks to the oxidation of oxygen. The mobility of these manganese ions would be at the origin of the hysteresis. 


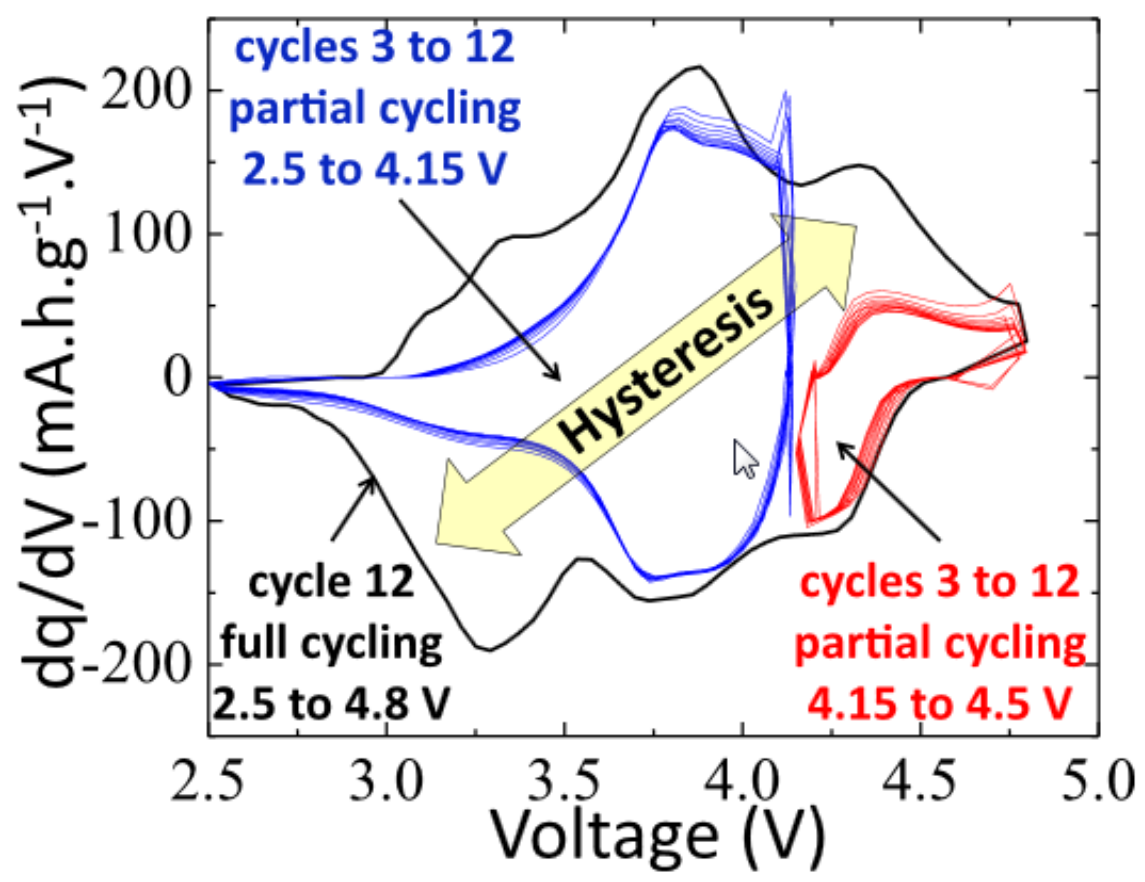

Figure 5 : Comparison of the electrochemical signatures obtained in different potential windows for the lithium batteries $\mathrm{Li} / / \mathrm{Li}_{1.20} \mathrm{Ni}_{0.20} \mathrm{Mn}_{0.60} \mathrm{O}_{2}$ : the hysteresis appears to be due to lithium deintercalation at high voltage $\left(\sim 4.4 \mathrm{~V} \mathrm{vs} \mathrm{Li}^{+} / \mathrm{Li}\right)$, the very end of the charge, and to its reintercalation only at very low voltage $(\sim 3.2 \mathrm{~V}$ vs. $\mathrm{Li}^{+} / \mathrm{Li}$ ) (reproduced from reference [52])

Peralta et al. have compared the electrochemical behavior of different compositions showing a decreasing $\mathrm{Li} / \mathrm{M}$ ratio from 2 for $\mathrm{Li}_{2} \mathrm{MnO}_{3}$ to 1.27 for $\mathrm{Li}_{1.12} \mathrm{Ni}^{2+}{ }_{0.32} \mathrm{Mn}^{4+}{ }_{0.56} \mathrm{O}_{2}$ with in each case the Li/Mn ratio maintained to 2 (Figure 6).[52] They have especially highlighted that the higher the manganese content, the more difficult it is to get the "full" capacity directly from the first cycle. A continuous increase in the reversible discharge capacity occurs during few cycles, concomitantly with the drastic and continuous voltage drop, before being stabilized. The voltage decay proceeds further even if following a smoother regime of decrease. Note that the higher the manganese content, the smaller the electronic conductivity and thus the more difficult it is to activate the participation of the oxygen to the redox processes. The increasing size of the particles makes even more difficult the spread of this reaction. The formation of $\mathrm{Mn}^{3+}$-defects, either within the pristine material or upon cycling to compensate for oxygen loss, helps promoting the initiation and the spread of the lithium de-intercalation and re-intercalation reactions within the particles, but - with the drawback - that 


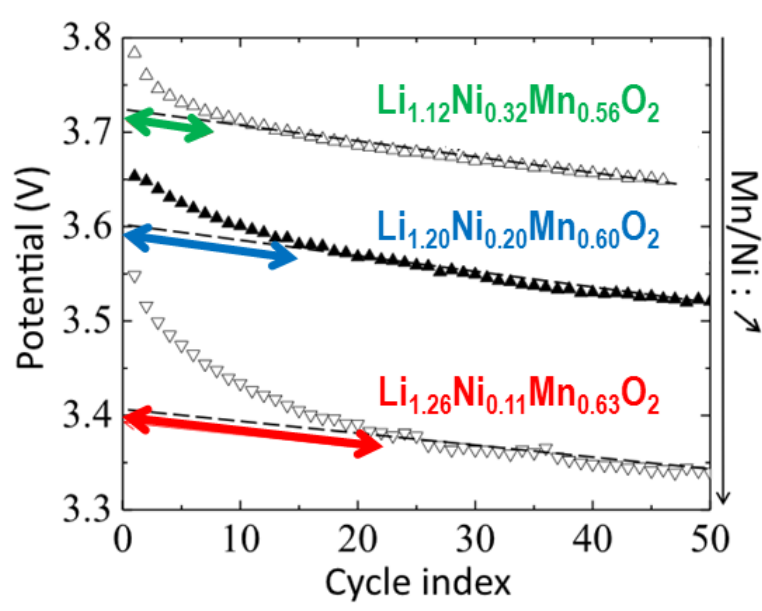

(a)

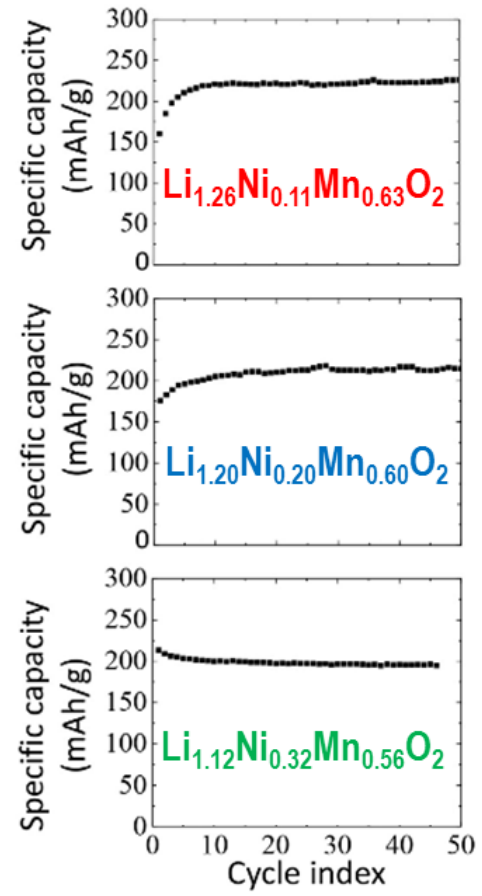

(b)

Figure 6: Comparison of three $\mathrm{Li}$ and Mn-rich layered oxides $\mathrm{Li}_{1.26} \mathrm{Ni}_{0.11} \mathrm{Mn}_{0.63} \mathrm{O}_{2}, \mathrm{Li}_{1.20} \mathrm{Ni}_{0.20} \mathrm{Mn}_{0.60} \mathrm{O}_{2}$ and $\mathrm{Li}_{1.12} \mathrm{Ni}_{0.32} \mathrm{Mn}_{0.56} \mathrm{O}_{2}$ : a) changes in the average discharge voltage upon cycling and $\mathrm{b}$ ) discharge capacity versus the number of cycles (adapted from reference [52])

it goes with a more largely cationic migration within the structure and thus voltage decay. This explains the tight relationship between the manganese content, the transport properties, the efficiency of the reaction and the voltage decay. Partial substitution of divalent nickel for tetravalent manganese helps as it participates, on one side to improve the transport properties thanks to the formation of the mixed valence state $\mathrm{Ni}^{2+/ 3+/ 4+}$, and on the other side to decrease the mobility of the transition metal ions within the framework (as $\mathrm{Ni}^{\mathrm{n+}}$ is not stable in tetrahedral site).

As a huge part of the electrochemical activity is linked to the participation of the oxygen to the redox processes, and as the irreversible part of this reaction is a surface reaction, efforts have been made to play on the specific surface area [39], [55] and to tune the particles' morphology [56]. The smaller the surface area and the denser the agglomerates, the less extended is the irreversible oxygen loss due to limited oxygen diffusion within the bulk. As expected, a major impact is observed on the extent of the mechanism involving a structural reorganization at the surface of the material, and thus on the heterogeneity at the local scale of the material obtained after a few cycles and finally of the magnitude of the voltage drop. 
Decreasing specific surface area induces better cyclability and smaller irreversible capacity. Even if complex, tailoring the morphology of the Li-rich layered oxides is also a route recently, and interestingly, explored. Oh et al. have shown as highlighted in Figure 7 that the controlled synthesis of flake-shaped primary particles allows preparing dense aggregates with a small specific surface area to minimize the oxygen loss and structural reorganization, but also promoting fast rate capability thanks to the preferential growth of the particles within the plane of the easier electron migration.

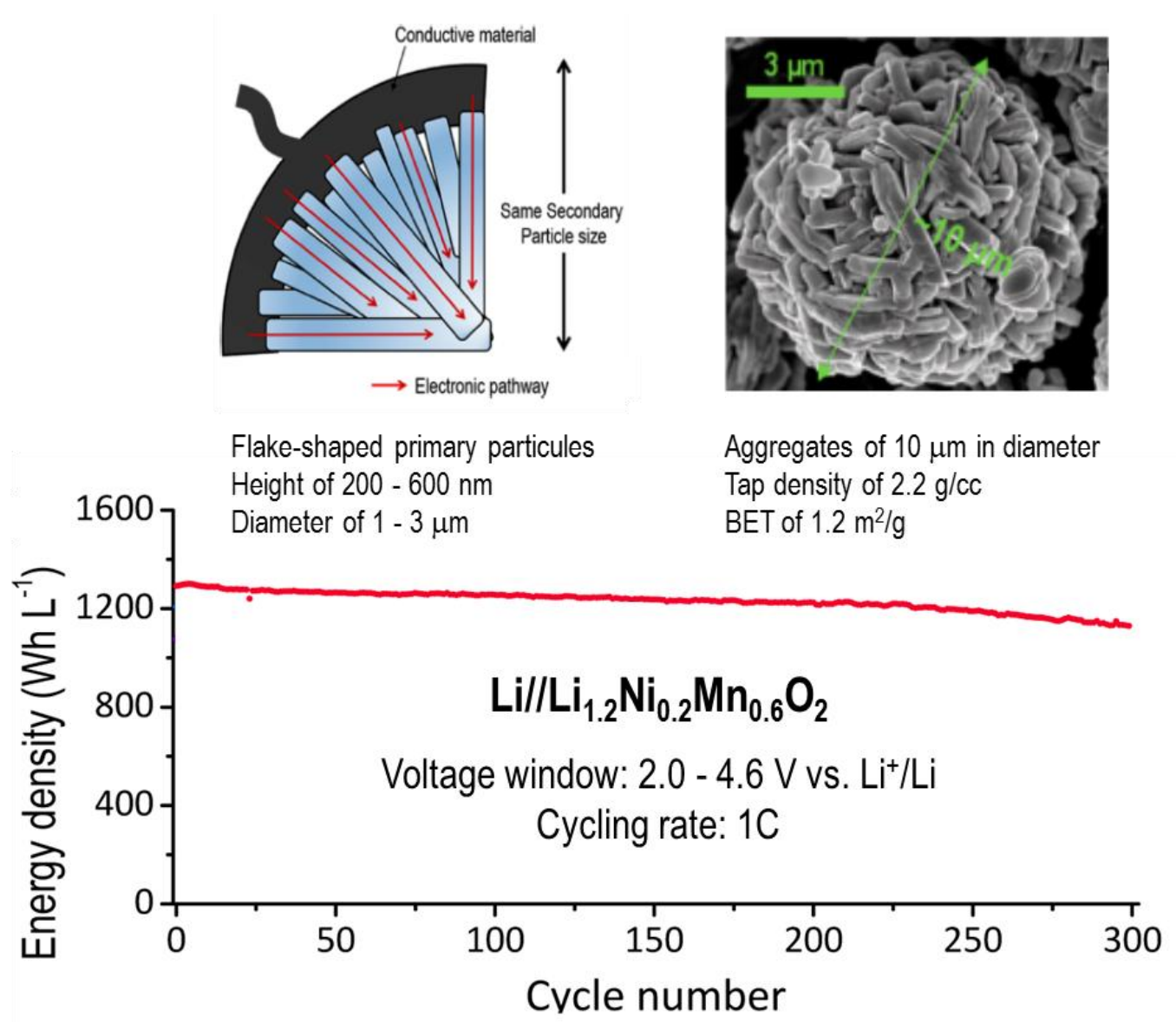

Figure 7: Flake-shaped primary particles in dense aggregates combining small specific surface area with rate capability and showing thus excellent energy retention (adapted from reference [55])

The extent of the cationic reorganization can be also quite different depending on the stoichiometry and thus oxidation state stabilized for each transition metal ion in the pristine material. [39], [46], [57]-[59]. High resolution HAADF-STEM and STEM-EELS analyses are crucial to get an in-depth description of the pristine material and of its changes upon cycling, from an atomic and electronic point of view. Indeed, any heterogeneity in the distribution of the transition metal ions or any discrepancy versus the $\mathrm{Li} / \mathrm{M}$ ratio such as to control the only tetravalent state for Mn make that $\mathrm{Mn}$ becomes active and promote more extended and faster 
cationic reorganization. From our knowledge of Mn-rich layered oxides we know that migration of $\mathrm{Mn}^{3+}$ upon tetrahedral sites to form spinel-type structures has already been largely observed previously for monoclinic- $\mathrm{LiMnO}_{2}$ [60], [61] and orthorhombic-LiMnO $\mathrm{H}_{2}$ [62]. In the Li and Mn-rich materials two phenomena can be considered, that related to the surface and oxygen loss, and that link to the presence of $\mathrm{Mn}^{3+}$-defects or heterogeneities locally in the pristine material that can initiate quite fast large cationic reorganization within the bulk towards spinel type structure, on the contrary to what is observed when the stoichiometry is fully tailored.[39], [45] As reported in references [46], [47], [63] the composition $\mathrm{Li}_{1.2} \mathrm{Ni}^{\mathrm{II}}{ }_{0.18} \mathrm{Mn}^{\mathrm{IV}}{ }_{0.59} \mathrm{Mn}^{\mathrm{III}}{ }_{0.02} \mathrm{Mg}_{0.01} \mathrm{O}_{2}$ was shown to contain manganese at the trivalent state in the pristine material but also heterogeneities at the local scale, with domains being clearly of $\alpha-\mathrm{NaFeO}_{2}$ type without any ordering in the slabs between the lithium and transition metal ions, and other domains being of $\mathrm{Li}_{2} \mathrm{MnO}_{3}$ type with an order in the slabs. The anionic redox activity was shown in that case to be rapidly limited with a fast voltage decay, but also - as clearly revealed by STEM-HAADF images combined with EELS analyses - a huge and extended cationic migration (preferentially of $\mathrm{Mn}$ ) resulting in the formation of a concentration gradient in $\mathrm{Mn}$ and in $\mathrm{Ni}$ within the densified domain present at the surface of the particles, this surface being enriched in Ni (Figure 8). The structure stabilized for the first atomic layers observed at the surface of the reconstructed material is "somewhere between" the layered $(R-3 m$ or $C 2 / m)$, spinel $(F d-3 m)$ and rock-salt $(F m-3 m)$ structures, mostly depending on the composition and structure of the pristine material and on the extent of the cycling. This cationic reorganization occurs at room temperature, thus as expected not perfectly, as it was discussed in reference [45]. 

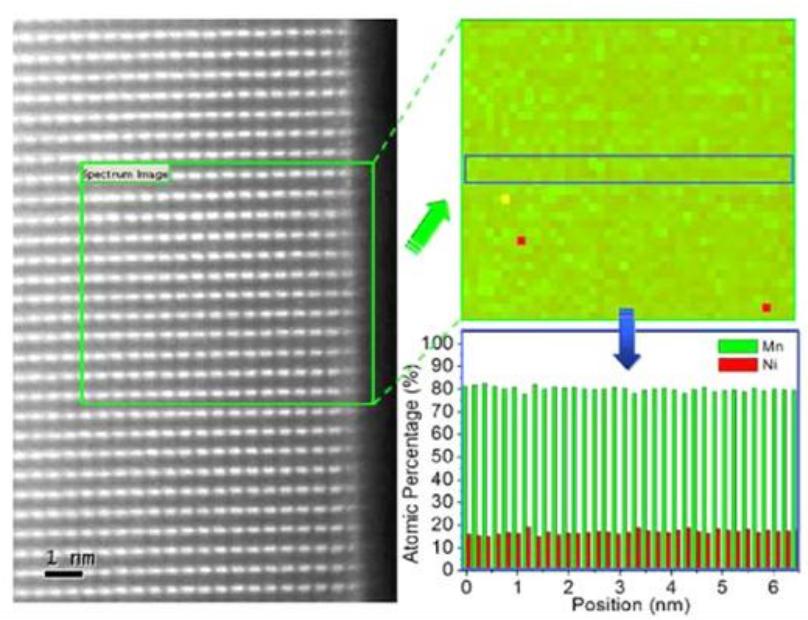

(a) Pristine material
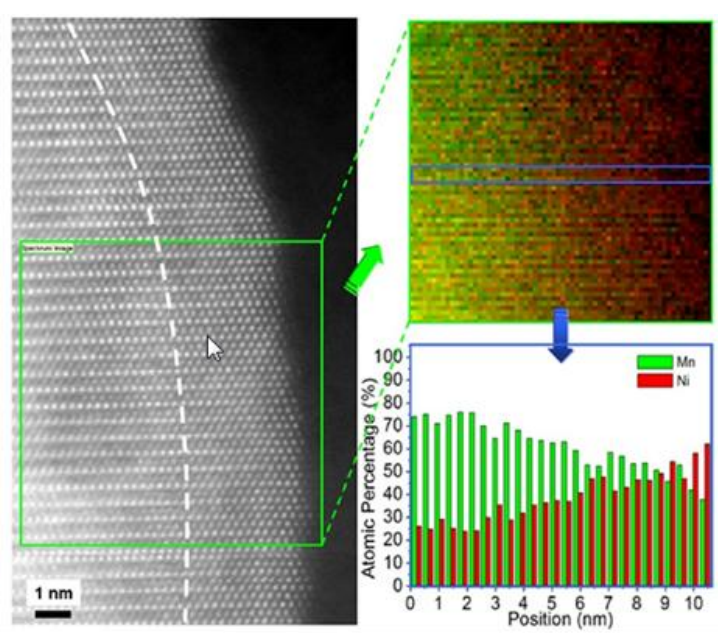

(b) After 50 cycles

Figure 8: High resolution STEM-HAADF images, the chemical maps and the corresponding graphs highlight changes in the content in $\mathrm{Mn}$ and in $\mathrm{Ni}$ obtained for the material $\mathrm{Li}_{1.2} \mathrm{Ni}_{0.18} \mathrm{Mn}_{0.61} \mathrm{Mg}_{0.01} \mathrm{O}_{2}$ : a) the pristine material and b) the material after 50 charge and discharge cycles at a $\mathrm{C} / 10$ rate. The dotted white line materialized the transition between the layered oxide phase and the spinel-type phase localized within the bulk and at the surface of the material respectively (adapted from the [46]).

Beyond the surface reconstruction of the active layered oxide materials, the oxygen released reacts irreversibly with the carbonate-based solvents of the electrolyte leading to the formation of a surface resistive layer made of decomposition products responsible for increasing polarization, deteriorated performance at high rates, etc. [64], [65]

Of course, maintaining the voltage below the voltage plateau prevents any activation and redox on the oxygen making thus that in a limited potential window the $\mathrm{Li}$ and Mn-rich compositions are stable and deliver performances similar to those of NMC, but at lower cost due to their high Mn content. Nevertheless, even if it remains challenging, it is clear that the mechanism involving anionic redox has to be stabilized in order to take benefit over a long range cycling of the exceptional properties it opens the road. Substitutions and exotic compositions were explored as possible tracks to stabilize these Li-rich compounds and allows, at least, to get the direct signature of the oxygen redox and further understanding into the anionic redox.

\section{Direct characterization of the oxidized oxygen species}

In the last five years the composition of the Li-rich layered oxides has been extended to exotic compositions, considering especially the $4 d$ transition metal ions such as $\mathrm{Ru}$, Mo and $\mathrm{Sn}$. These results revealed that by playing with the layered oxides' composition it is possible to 
stabilize the anionic redox reaction, even at the surface, and as a consequence to maintain a large reversible capacity upon long range cycling without voltage and energy decay. Sathiya et al. studied a series of compositions $\mathrm{Li}_{2} \mathrm{Ru}_{1-\mathrm{y}} \mathrm{Sn}_{\mathrm{y}} \mathrm{O}_{3}(0 \leq \mathrm{y} \leq 1)$ which deliver discharge capacities ranging between 50 and $200 \mathrm{mAh} / \mathrm{g}$ for $\mathrm{y}=1$ and 0 respectively.[59], [66], [67] The voltage decay was shown to decrease with the increasing content in Sn, and to be negligible after 100 cycles for the composition $\mathrm{y}=0.75$ as $\mathrm{Sn}^{4+}$ ions are not stable in tetrahedral sites, the required pathway between the slabs and the interslab spaces (Figure 9). On the contrary, by replacing $\mathrm{Ti}$ for $\mathrm{Sn}$ in $\mathrm{Li}_{2} \mathrm{Ru}_{1-\mathrm{y}} \mathrm{Ti}_{\mathrm{y}} \mathrm{O}_{3}$ the voltage decay was even more pronounced. As soon as the shortening of the O-O bonds occurs due to the oxidation of oxygen to compensate for Li deintercalation along the plateau (Figure 10), $\mathrm{Ti}^{4+}$ ions migrate from their highly distorted environments to the neighboring tetrahedral sites where
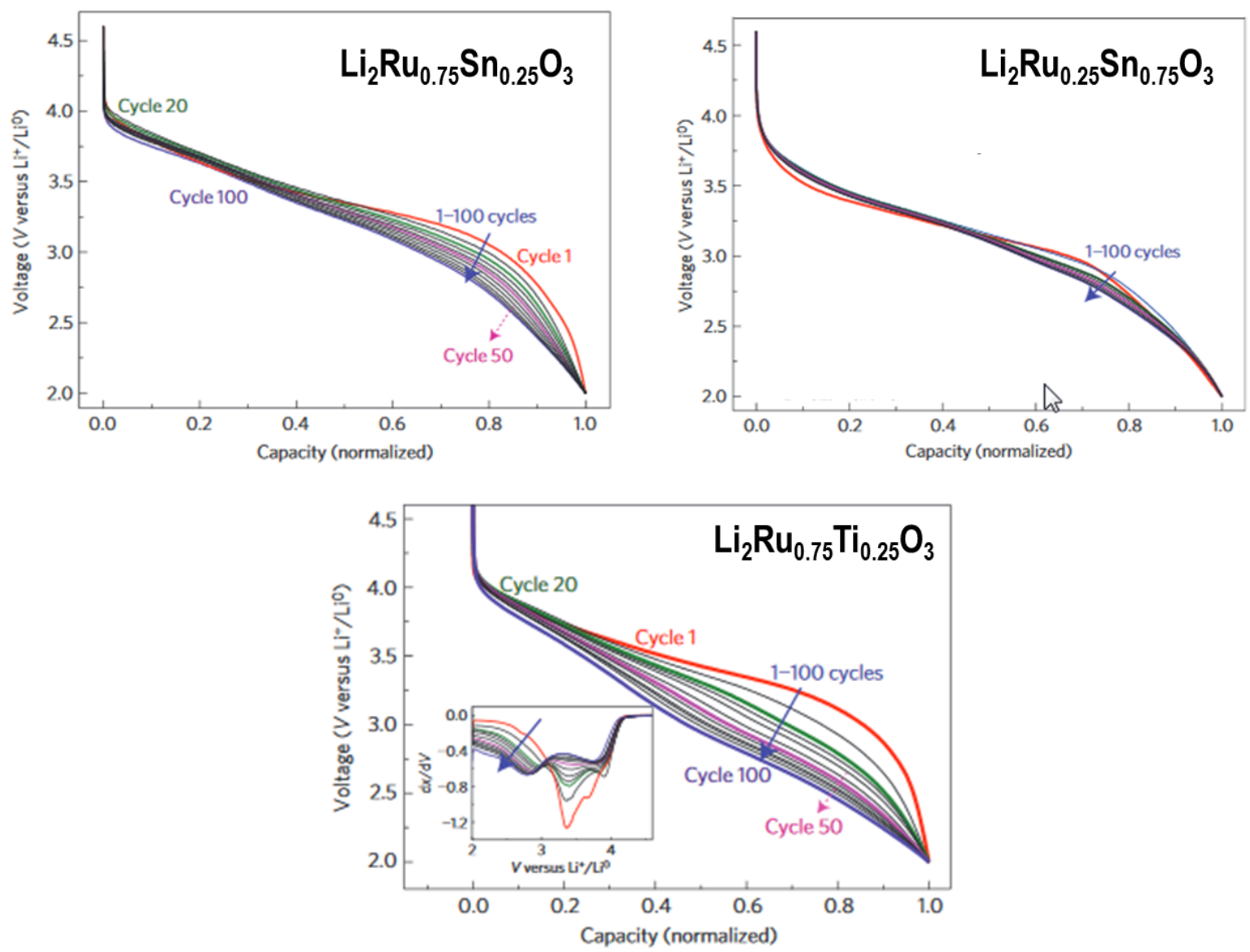

Figure 9: Normalized capacity discharge profiles obtained for $\mathrm{Li}_{2} \mathrm{Ru}_{0.75} \mathrm{Sn}_{0.25} \mathrm{O}_{3}, \mathrm{Li}_{2} \mathrm{Ru}_{0.25} \mathrm{Sn}_{0.75} \mathrm{O}_{3}$ and $\mathrm{Li}_{2} \mathrm{Ru}_{0.75} \mathrm{Ti}_{0.25} \mathrm{O}_{3}$ every 10 cycles during the first 100 cycles performed at $\mathrm{C} / 5$ between 2 and $4.6 \mathrm{~V} \mathrm{vs} . \mathrm{Li}^{+} / \mathrm{Li}$. (Adapted from reference [67]). 


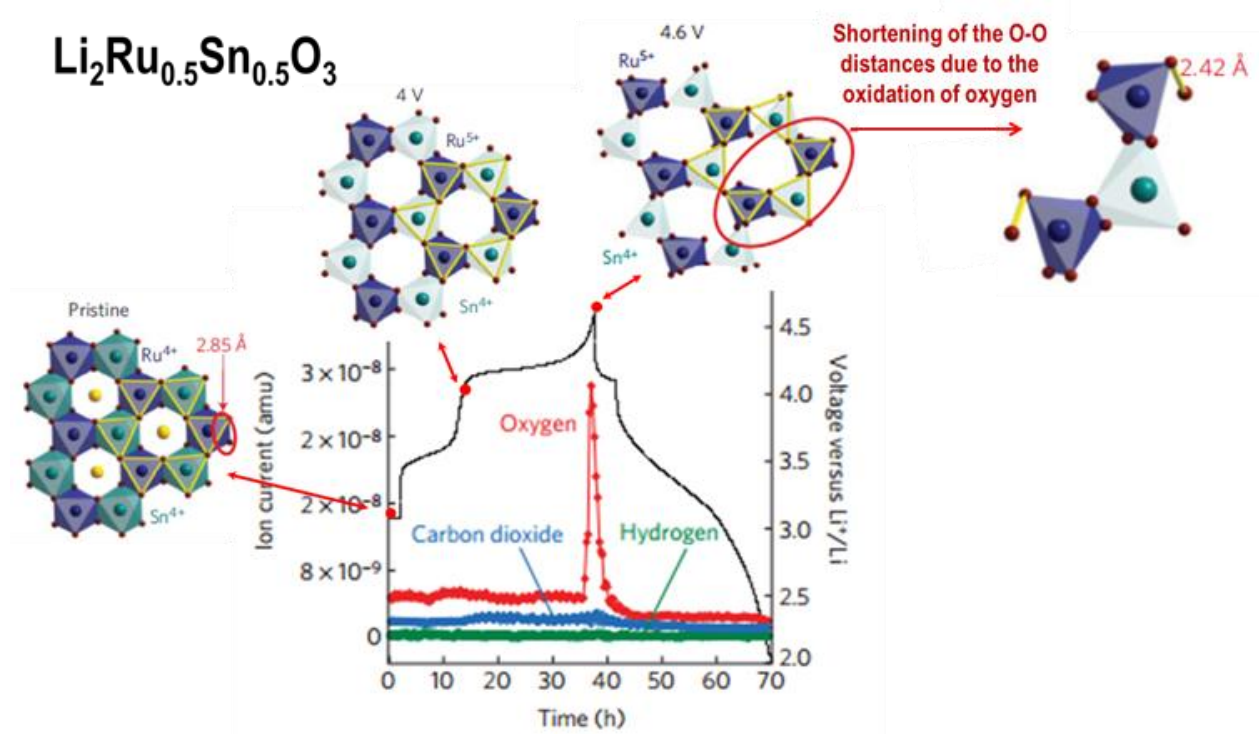

Figure 10: First charge and discharge obtained for a $\mathrm{Li} / / \mathrm{Li}_{2} \mathrm{Ru}_{0.5} \mathrm{Sn}_{0.5} \mathrm{O}_{3}$ cell with the gas profiles of $\mathrm{CO}_{2}, \mathrm{H}_{2}$ and $\mathrm{O}_{2}$ "detected" at room temperature. Note that the oxygen release was only obvious at the very end of the charge. The description of the $\left(\mathrm{Li}_{1 / 3} \mathrm{Ru}_{1 / 3} \mathrm{Sn}_{1 / 3}\right) \mathrm{O}_{2}$ slab is given at each step of the charge ( $\mathrm{Li}$ in yellow, $\mathrm{Ru}$ in violet and $\mathrm{Sn}$ in green): before the plateau $\mathrm{Ru}^{4+}$ is oxidized to $\mathrm{Ru}^{5+}$ to compensate for the deintercalation of 0.5 $\mathrm{Li}^{+}$, during the plateau the further Li deintercalation is compensated by the oxidation of the oxygen anions which leads to a shortening of the O-O distances (from 2.85 to $2.42 \AA$ ) and to a strong distortion of the $\mathrm{Ru}$ and $\mathrm{Sn}$ first coordination spheres. (Adapted from reference [66])

they can be stabilized. The signature of the anion participation to the redox processes and thus of its oxidation at the end of the charge was obtained combining different spectroscopies.[66] The detection of a component at $\sim 530.5 \mathrm{eV}$, in good agreement with the presence of oxygen with lower electronic density than in $\mathrm{O}^{2-}$ at the surface of the material, was achieved by XPS. The formation of these oxidized oxygen species within the bulk of the material was confirmed by EPR that revealed the appearance at high voltage of a signal typical of peroxide/superoxide type species ( similar to that of $\mathrm{CaO}_{2}$ ). This signal was estimated to correspond to $23 \pm 6 \%$ of the oxygen for $\mathrm{Li}_{2} \mathrm{Ru}_{0.5} \mathrm{Sn}_{0.5} \mathrm{O}_{3}$ (i.e. a significant amount). The factors governing the stability of the Li-rich layered oxides versus oxygen release in their highly de-intercalated compositions, and thus the reversibility of the anionic redox, has been studied by theoretical calculations tuning the compositions of $\mathrm{Li}_{2} \mathrm{MO}_{3}$, considering $3 d, 4 d$ and $5 d$ transition metal ions but also a Li/M ratio ranging from 2 to 0.[68] Interestingly, it appears that oxygen releases is expected for all the $3 d$ transition metal ions, and that the reversibility of the anionic redox would be reached only for Li-rich layered oxides containing the heavier $4 d$ and $5 d$ transition metals as in that case the antibonding $\left(\mathrm{MO}^{*}\right)$ states of the d-band and the pure $\mathrm{O}(2 \mathrm{p})$ localized states of the p-band are expected to be both at the Fermi level. The presence of the $\mathrm{O}(2 \mathrm{p})$ states only at the Fermi level leads to the formation of pure oxidized oxygen 
species, either as radicals $\left(\mathrm{O}^{-}\right)^{\bullet}$ or as peroxides $\left(\mathrm{O}_{2}\right)^{2-}$. They are highly unstable and reactive, and thus released leading to the irreversibility of the anionic redox.

Recently, complementary insights were brought by the groups of P.G. Bruce [69] and G. Ceder [70] to understand the role of oxygen in the redox activity of typical lithium-ion battery electrode materials such as $\mathrm{Li}_{1.2} \mathrm{Mn}_{0.54} \mathrm{Ni}_{0.13} \mathrm{Co}_{0.13} \mathrm{O}_{2}$ [71] Combining different spectroscopies (SXAS, RIXS, Raman and XANES) to probe directly the oxygen states, lithium deintercalation on the plateau was shown to be compensated through the formation of localized electron holes on the oxygen anions coordinating mainly the $\mathrm{Mn}^{4+}$ and $\mathrm{Li}^{+}$in excess in the slabs [69]. Indeed, only $9 \%$ of the capacity delivered on the plateau is compensated by oxygen loss. Furthermore, the elastic peak observed from the beginning of the plateau in the RIXS spectra, with an excitation energy of $531.8 \mathrm{eV}$ and an increasing intensity, indicates the formation of localized holes on the oxygen states (figure 11), whereas the transition metal Kedge XANES spectra reveal that the oxygen anions reversibly involved in the redox processes are in the vicinity of $\mathrm{Mn}^{4+}$ and $\mathrm{Li}^{+}$that form more ionic bonds with oxygen than $\mathrm{Co}^{4+}$ and $\mathrm{Ni}^{4+}$. Raman spectroscopy, which is highly sensitive to the formation of peroxo-like species, reveals that true peroxo-like species are not formed upon lithium deintercalation from $\mathrm{Li}_{1.2} \mathrm{Mn}_{0.54} \mathrm{Ni}_{0.13} \mathrm{Co}_{0.13} \mathrm{O}_{2}$. Seo et al. studied using DFT how important is the nature of the cations localized around the oxygen anions in order to promote their participation to the redox processes [70], varying the amount of $\mathrm{Li}^{+}$ions around an oxygen from two (in the interslab space) to four (three in the interslab space and one in excess in the slab). In fact, the oxygen anions involved

(a)

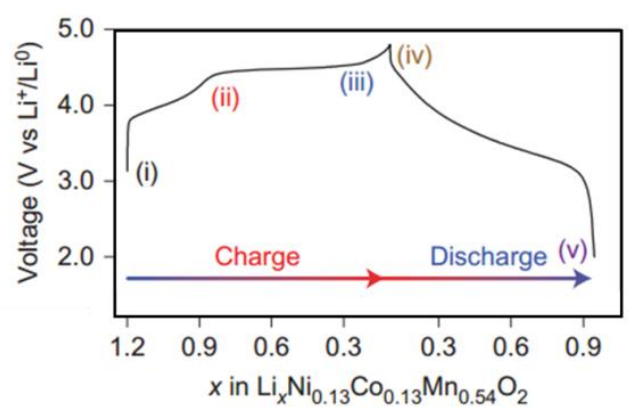

(b)

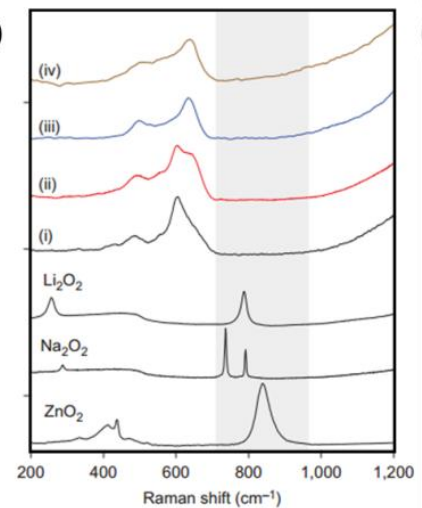

(c)

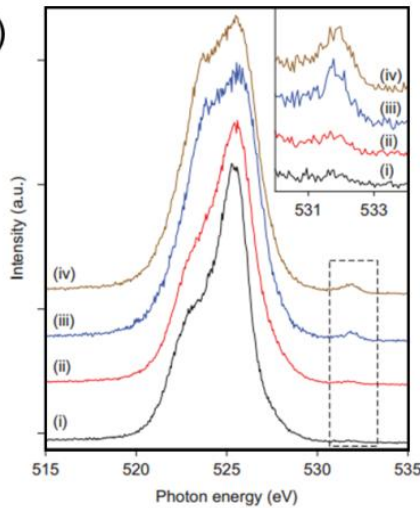

Figure 11: First charge and discharge obtained for a lithium cell $\mathrm{Li} / / \mathrm{Li} 1.2 \mathrm{Mn}_{0.54} \mathrm{Ni}_{0.13} \mathrm{Co}_{0.13} \mathrm{O}_{2}$ and indicating compositions recovered at different states of charge or discharge (labelled (i) to (v)) (a), the Raman spectra of compositions (i) to (iv) compared to those of three reference peroxide samples $\mathrm{Li}_{2} \mathrm{O}_{2}, \mathrm{Na}_{2} \mathrm{O}_{2}$ and $\mathrm{ZnO}_{2}$ (b), and the RIXS spectra of the same compositions with given in inset the excitation band observed at $531.8 \mathrm{eV}$ (c). (Adapted from the reference [69]). 
in a $180^{\circ} \mathrm{Li}_{\text {Slab }}-\mathrm{O}-\mathrm{Li}_{\text {Interslab }}$ configuration are those prompted to be oxidized, since as also discussed by Xie et al. their energy is increased and shifted close to the antibonding transition metal d-states because along that direction the oxygen $2 p$ orbitals are not hybridized with transition metal $d$ orbitals. Depending on the nature of the transition metal ion $\mathrm{M}$ in the immediate environment of oxygen $\mathrm{O}\left(\mathrm{Li}_{4} \mathrm{M}_{2}\right)$, there is a redox activity of the cations and/or of the anions.

\section{Perspectives for reversible redox on oxygen ions}

It appears that in these Li-rich two dimensional structures it is possible to form a three dimensional percolating network of vacancies bringing into play the slabs and interslab spaces to ensure the Lithium diffusion and so to optimize capacity and performances at high rate: $\mathrm{x}=$ 1.09 would be the percolation threshold for $\mathrm{Li}_{\mathrm{x}} \mathrm{M}_{2-\mathrm{x}} \mathrm{O}_{2}$ (whatever its structure: layered, spinel, disordered, or rock-salt), while $x>1.22$ would allow reaching a reversible capacity of $1 \mathrm{Li}^{+}$ per transition metal [72]. Combining anionic redox with this infinity of materials known as "Li-rich" opens new horizons for the development of high energy density positive electrode materials for Lithium-ion batteries. A large panel of compositions enriched in lithium has been already explored: for instance, cation disordered rock-salt structures such as $\mathrm{Li}_{1.211} \mathrm{Mo}_{0.467} \mathrm{Cr}_{0.3} \mathrm{O}_{2}$ [72], $\mathrm{Li}_{1.33} \mathrm{~V}_{0.67} \mathrm{O}_{1.33} \mathrm{~F}_{0.67}$ [73], (1-y) $\mathrm{Li}_{3} \mathrm{NbO}_{4} \cdot \mathrm{yLiMO}_{2}\left(\mathrm{M}=\mathrm{Fe}^{3+}, \mathrm{Mn}^{3+}\right.$, $\mathrm{V}^{3+}$ ) [74]-[76], $\mathrm{Li}_{1.2} \mathrm{Ti}_{0.4} \mathrm{Mn}_{0.4} \mathrm{O}_{2}$ [76] and $\mathrm{Li}_{4} \mathrm{MoO}_{5}$ [77], the three-dimensional ordered $\beta$ $\mathrm{Li}_{2} \mathrm{IrO}_{3}$ [78] and the nanostructured rock-salt type $\mathrm{Li}_{4} \mathrm{Mn}_{2}\left\{\mathrm{O}_{5} \square_{1}\right\}$ [79]. As for the Li-rich layered oxides, the charge compensation for lithium deintercalation depends on the nature of the transition metal ions in $\mathrm{Li}_{\mathrm{x}} \mathrm{M}_{2-\mathrm{x}} \mathrm{O}_{2}$ : for instance, for $\mathrm{Li}_{1.3} \mathrm{Nb}_{0.3} \mathrm{Fe}_{0.4} \mathrm{O}_{2}$ only oxygen participates to the redox processes, for $\mathrm{Li}_{1.3} \mathrm{Nb}_{0.3} \mathbf{M n}_{0.4} \mathrm{O}_{2}$ manganese and oxygen are involved whereas for $\mathrm{Li}_{1.3} \mathrm{Nb}_{0.3} \mathbf{V}_{0.4} \mathrm{O}_{2}$ a two electron cation redox occurs [76]. Interestingly, a $\mathrm{Nb}$-free composition $\mathrm{Li}_{1.2} \mathrm{Ti}_{0.4} \mathrm{Mn}_{0.4} \mathrm{O}_{2}$ was identified to deliver (at $50^{\circ} \mathrm{C}$ ) a high reversible capacity of $300 \mathrm{mAh} / \mathrm{g}$ and energy density of $1000 \mathrm{Wh} / \mathrm{kg}$, that later exceeding that expected for $\mathrm{Li}_{2} \mathrm{MnO}_{3}$. The results recently reported for $\beta-\mathrm{Li}_{2} \mathrm{IrO}_{3}$ have also confirmed that reversible anionic redox is possible in three-dimensional structures, but also that it can be activated at potentials as low as $3.4 \mathrm{~V}$ vs. $\mathrm{Li}^{+} / \mathrm{Li}$ [78]. Furthermore, the three-dimensional structure would be beneficial as it allows, at least for $\beta-\mathrm{Li}_{2} \mathrm{IrO}_{3}$, a complete lithium deintercalation without any structural reorganization upon cycling. $\mathrm{Li}_{1.2} \mathrm{Ti}_{0.4} \mathrm{Mn}_{0.4} \mathrm{O}_{2}$ (at $50^{\circ} \mathrm{C}$ ) and $\beta-\mathrm{Li}_{2} \mathrm{IrO}_{3}$ (with a reversible capacity of $200 \mathrm{mAh} / \mathrm{g}$ ) appear thus as proofs of concept that open the road for a 
wider prospection of three-dimensional oxides enriched in lithium, involving anionic redox in stable oxide structures of positive electrode materials for high energy lithium-ion batteries.

\section{B. The Lithium and Manganese rich layered oxides as composite materials}

One of the most challenging, but also promising, positive electrode materials remains the Li and Mn-rich, as its introduction in the next generation of Lithium-ion batteries would directly induce a $25 \%$ increase in energy density for the full cell. Nevertheless, as discussed just before its stability is still too limited to consider it ready for commercialization. Two major degradation phenomena can be observed: $(i)$ an irreversible modification of the material upon cycling, depending on the composition it is spread into the bulk or strictly limited to the interface with the electrolyte. A partial transition metal dissolution (mainly manganese) can be also observed, (ii) the oxidation of the electrolyte at high voltage that can induce the formation of a resistive layer at the interface electrode-electrolyte and a drastic loss of capacity. The use of the Li-rich layered oxides in Lithium-ion batteries is thus facing challenging problems to be solved. Different tracks can be followed, such as: $(i)$ driving the potential slightly down through partial substitution in order to mitigate all the electrolyte degradation reactions, (ii) tailoring the particle morphology in order to promote the preferential growth of less reactive crystallographic oriented surfaces [56], (iii) modifying the surface of the active material through the formation of an inorganic or organic coating, electrochemically active or not, formed ahead or upon cycling through the addition of additives in the electrolyte, in order to stabilize the structure at the surface of the active material and to limit the reactivity at the solid-liquid interface, (iv) covering the surface of the electrode in order to minimize any degradation reaction with any component of the electrode (active material, carbon additive and polymeric binder) and $(v)$ prospecting material engineering through the formation of core-shell or concentration gradients. The investigation of these five tracks is interesting as fundamental science and understanding are required in order to step further in the direction of the material engineering in the field of materials for lithium-ion batteries. Furthermore, the benefit of the protection of the active surfaces or of material engineering can be a partial answer to surface reactivity, but also to limitations in thermal stability and rate capability.

\section{The benefit of blends and of coatings}


The blends used as positive electrode materials for Lithium-ion batteries are macroscopic mixtures of active materials, i.e. made at the scale of the aggregates. Nevertheless, they have already been shown to answer many of the concerns faced by the complex chemistry involved in a Lithium-ion battery, with electrode materials and electrolytes being often at the limit of their chemical stability. They lead in some cases to the reduction of the irreversible capacity and to the increase of the cyclability, energy and power densities and thermal stability of the batteries [80], [81]. For instance, mixtures made of the spinel phase $\mathrm{Li}_{1+\mathrm{x}} \mathrm{Mn}_{2-\mathrm{x}} \mathrm{O}_{4}$ (the main phase) and of a layered oxide such as $\mathrm{LiCoO}_{2}$ [82], $\mathrm{LiNi}_{1 / 3} \mathrm{Mn}_{1 / 3} \mathrm{Co}_{1 / 3} \mathrm{O}_{2}$ [83] or $\mathrm{LiNi}_{0.8} \mathrm{Co}_{0.2} \mathrm{O}_{2}$ [84] (the minor phase) have been shown to mitigate the manganese dissolution within the electrolyte and thus to improve the electrochemical performances. These layered oxides would act as scavengers of $\mathrm{H}^{+}$formed upon cycling, before the detrimental formation of $\mathrm{HF}$ at the origin of the transition metal dissolution. The combination of the carbon coated olivine $\mathrm{LiFePO}_{4}$ with layered oxides has also been reported to be efficient in high rate conditions, with $0.5 \mathrm{Li}_{2} \mathrm{MnO}_{3} .0 .5 \mathrm{LiNi}_{0.44} \mathrm{Mn}_{0.31} \mathrm{Co}_{0.25} \mathrm{O}_{2}$ [85], $\mathrm{LiCoO}_{2}$ [86] and $\mathrm{Li}_{1.17} \mathrm{Ni}_{0.25} \mathrm{Mn}_{0.58} \mathrm{O}_{2}$ [87] as layered oxides. The benefit of blends is that the total weight of the material is electrochemically active, nevertheless the nature of the mixture or engineering of that blend (a simple mixture, a mixture layer by layer ...) can by itself have a huge impact on the actual properties.

To reach the attractive reversible capacity of Lithium-rich layered oxides the cycling has to be performed beyond $4.6 \mathrm{~V}$ vs. $\mathrm{Li}^{+} / \mathrm{Li}$, in a potential window in which the stability of the carbonate-based liquid electrolytes is limited and thus detrimental to the surface stability of the active material, for instance versus transition metal dissolution. The development of active materials with a coating is thus an interesting strategy. Depending on their chemical nature, they can act as scavengers for HF and prevent any surface dissolution [88], or they can mitigate the catalytic effects of oxidized transition metal ions versus electrolyte decomposition. They can also improve the electronic conductivity of the composite and thus the performance at higher cycling rates, or the thermal stability in the charged state of the battery. Note that whatever its nature and morphology, the coating must not be detrimental to the lithium diffusion through the active material and electrode [89], [90]. These inorganic coatings can be oxides such as $\mathrm{Al}_{2} \mathrm{O}_{3}$ [88]-[90], $\mathrm{CuO}$ [91], $\mathrm{MgO}$ [92], $\mathrm{Li}_{3} \mathrm{VO}_{4}$ [93], $\mathrm{ZrO}_{2}$ [94], [95], ... or fluorides such as $\mathrm{CaF}_{2}$ [96] and $\mathrm{AlF}_{3}$. These coatings can be differently prepared and distributed over the active material. [92] The coverage can be total as a thin layer at the surface of the single particles present, either at the surface of the aggregates only, 
or even within the aggregates (with thus a penetration in all the grain boundaries). Deposition methods revealed to be the technique of choice to form uniform films: the chemical vapor deposition (CVD) allows the formation of a very homogenous coating impregnating the surface and the porosity of the powders/electrodes but with a low deposition rate, the pulsed laser deposition method (PLD) and the atomic layer deposition (ALD [7]) are much more adapted to prepare these coatings as the first is already used to prepare solid electrolytes in all-solid-state microbatteries for instance, and the second widely used in the OLEDs field to prepare at low temperature thin layers as barriers against water permeation and with controlled thickness and composition without defects. The coverage can be also partial, with small particles at the surface of the aggregates and within the grain boundaries. Depending on the synthesis method used to prepare this coating, either it is a second phase next to the active material, or it reacts partially during its formation at the surface of the active material to form a composite coating-interphase-active material, the interphase resulting from the partial interdiffusion of the cations between the coating and the active material. Depending on the reactivity of the phase chosen for the coating and despite an often limited covering of the surface, the benefit can be significant and "total" as for instance HF will react preferentially with these particles of large surface area that will act as scavengers and stabilize the material.

Most of the coatings are dead mass and their weight has thus to be limited in order to maintain a good reversible capacity delivered by the electrode and, as discussed already, not to be at the origin of an increasing resistive layer within the electrode, blocking the lithium diffusion and electron percolation. Their weight is often limited to a few percents. In order to overpass this drawback, new systems are under development, such as core-shells or concentration gradients, in which all the material is active, from the surface to the bulk. The goal here is thus to combine the good properties from the phase(s) present within the bulk with those from the phase(s) present more at the surface, in the external part of the aggregates or of the single particles, in order to develop an optimized material combining energy and power densities as well as thermal stability [97]-[100]. The main problems faced by these composites are: $(i)$ the possible strong volume variations that can be observed upon cycling between the different components of the composite, which could be at the origin of decohesion within the aggregates and electrodes [101], [102], and (ii) the complex syntheses that required to be developed to control their composition, morphology and tap density for instance. In the following we will focus our discussion on the synthesis of these new materials issued from material engineering. 


\section{The concentration gradients}

The full concentration gradients (FCG) were initiated for the first time for the layered oxides in the field of positive electrode materials for Li-ion batteries by the group of Y.K. Sun in 2009 [103]. These compounds are prepared as spherical aggregates with interlocked primary particles. The composition of the particles present at the surface is different from that of the particles present in the bulk, with a continuous change in the transition metal concentrations from the surface to the bulk as schematized in Figure 12. The target of such an engineering is to combined different properties within the same materials, fundamental properties for the development of optimized positive electrode materials: high energy and/or power density, chemical and thermal stability ...

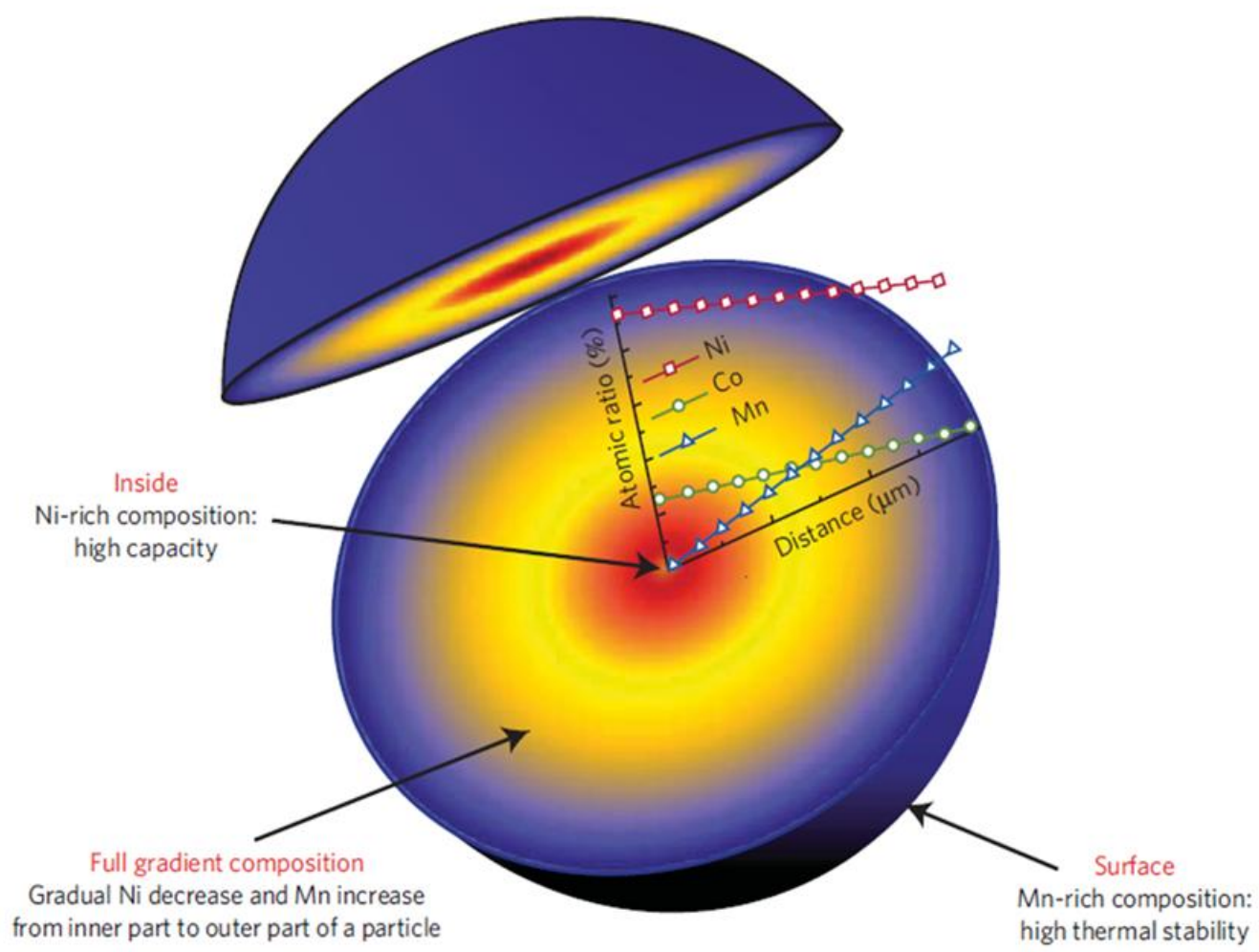

Figure 12: Schematic representation of a spherical aggregate for the layered oxide of average composition $\mathrm{LiNi}_{0.75} \mathrm{Mn}_{0.15} \mathrm{Co}_{0.10} \mathrm{O}_{2}$ and showing a concentration gradient: that latter implies a decrease in the concentration of $\mathrm{Ni}$ and $\mathrm{Co}$ from the bulk to the surface, and on the contrary an increasing concentration in Mn (adapted from the reference [104]). 


\section{a) Their synthesis by coprecipitation}

Most of the concentration gradients were obtained for the Ni-rich layered oxides. Only few syntheses were reported for $\mathrm{Li}$ and $\mathrm{Mn}$-rich layered oxides. All the concentration gradients were obtained by coprecipitation. Depending on the target composition and structure, the synthesis conditions can be very different playing with the $\mathrm{pH}$, nature and concentration of the precursors in the pristine preparations, feeding rates of the transition metal preparations within the precipitation solution, temperature of the reactor, stirring rate and temperature of the thermal treatment performed to obtain in a second step the oxide. The tables given hereafter summarize a large panel of compositions, with the synthesis conditions used to prepare them as concentration gradients: the nickel rich layered oxides are given in Tables I and II and the manganese rich layered oxides in Table III. The intermediate compound issued from the precipitation can be a mixed carbonate or hydroxide, prepared with the targeted concentration gradient in transition metals. The $\mathrm{pH}$ required for the precipitation is of the order of 11 for the nickel rich layered oxides and of 7.5 - 8 for the manganese rich layered oxides. The temperature of the thermal treatment applied to obtain then the layered oxides is close to $750^{\circ} \mathrm{C}$ for the Ni-rich and above $900^{\circ} \mathrm{C}$ for the Co and Mn-rich. Furthermore, the diameter of the aggregates is typically of the order of $8-15 \mu \mathrm{m}$, a size big enough to control the formation of the concentration gradient, the size of the primary particles being often well below $1 \mu \mathrm{m}$. That synthesis process in solution allows an intimate mixing of all the precursors and favors a better statistical and homogeneous distribution of the transition metals at the atomic scale. Two pristine sulfate solutions are prepared, the first one corresponding to the composition of the surface. During the precipitation the first sulfate solution is introduced continuously in the second one, which is then introduced into the reactor. All the solutions are maintained under stirring. The concentration of the transition metal ions in the second solution is thus continuously modified in order to prepare the gradient. Separately, a basic solution made of ammonium hydroxide $\left(\mathrm{NH}_{4} \mathrm{OH}\right)$, used as chelating agent, and of sodium carbonate $\left(\mathrm{NaCO}_{3}\right)$ (or sodium hydroxide, $\mathrm{NaOH}$ ), used as precipitating agent, is added in the reactor such as to maintain the $\mathrm{pH}$ to the target value that allows the precipitation of $\mathrm{Ni}, \mathrm{Mn}$ and $\mathrm{Co}$ species all together. The solution thus obtained is then continuously stirred during few hours, before the precipitate is filtered, washed with deionized water and dried. The mixed carbonate (or hydroxide) of transition metal ions thus obtained is treated at high temperature with a lithium precursor such as $\mathrm{Li}_{2} \mathrm{CO}_{3}$ or $\mathrm{LiOH}$ to form the lithiated oxides. In general, the nickel rich layered oxides are calcined under $\mathrm{N}_{2}$, whereas those rich in $\mathrm{Mn}$ are calcined under air. All the 
average compositions of the intermediates prepared as concentration gradients are gathered in Figure 13, as crosses for the hydroxides and as circles for the carbonates, most of them being rich in $\mathrm{Ni}$, with a nickel rich core and a manganese rich surface in order to combine within the same electrode material high capacity, cyclability and thermal stability at the charged state of the battery. Indeed, the core rich in Ni brings the high capacity, whereas the surface or the external crown is responsible for the thermal stability. The concentration gradient in such an engineered material allows to create a synergy of properties. 
Table I: Summary of the conditions used to prepare concentration gradients of layered oxides rich in nickel as reported in different papers. Some conditions are missing because they were not reported by the authors themselves

\begin{tabular}{|c|c|c|c|c|c|c|c|c|c|}
\hline Reference & $\begin{array}{l}\text { Average composition } \\
\text { (reported as a number in } \\
\text { Figure 13) }\end{array}$ & Bulk composition & Surface composition & $\begin{array}{l}\text { Tank } \\
\text { volume } \\
\text { (L) }\end{array}$ & $\begin{array}{l}\text { Concentrations of } \\
\text { the transition } \\
\text { metal solution } \\
\text { and of the basic } \\
\text { solutions } \\
\end{array}$ & $\mathrm{pH}$ & $\begin{array}{l}\text { Stirring conditions } \\
\text { (temperature, speed. } \\
\text { atmosphere) }\end{array}$ & $\begin{array}{c}\text { Calcination } \\
\mathrm{T}\left({ }^{\circ} \mathrm{C}\right) \mathrm{t}(\mathrm{hrs}) \\
\text { (Lithium precursor) }\end{array}$ & $\begin{array}{l}\text { Size of the aggregates (primary } \\
\text { particles) in the intermediate } \\
\text { precursor / oxide }\end{array}$ \\
\hline$[103]$ & $\mathrm{LiNi}_{0.64} \mathrm{CO}_{0.18} \mathrm{Mn}_{0.18} \mathrm{O}_{2}(1)$ & $\operatorname{LiNi}_{0.80} \mathrm{CO}_{0.10} \mathrm{Mn}_{0.10} \mathrm{O}_{2}$ & $\mathrm{LiNi}_{0.46} \mathrm{CO}_{0.23} \mathrm{Mn}_{0.31} \mathrm{O}_{2}$ & & & & & $780^{\circ} \mathrm{C} 20 \mathrm{hrs}\left(\mathrm{LiNO}_{3}\right)$ & $14 \mu \mathrm{m} / 14 \mu \mathrm{m}$ \\
\hline [105] & $\mathrm{LiNi}_{0.72} \mathrm{Co}_{0.18} \mathrm{Mn}_{0.10} \mathrm{O}_{2}(2)$ & $\frac{\mathrm{LiNi}_{0.80} \mathrm{CO}_{0.20} \mathrm{O}_{2}}{\mathrm{~N}}$ & $\mathrm{LiNi}_{0.55} \mathrm{CO}_{0.15} \mathrm{Mn}_{0.30} \mathrm{O}_{2}$ & & & & & $750^{\circ} \mathrm{C} 20 \mathrm{hrs}$ (LiOH) & $14 \mu \mathrm{m} / 14 \mu \mathrm{m}$ \\
\hline [106] & $\mathrm{LiNi}_{0.67} \mathrm{Co}_{0.15} \mathrm{Mn}_{0.18} \mathrm{O}_{2}(3)$ & $\mathrm{LiNi}_{0.8} \mathrm{Co}_{0.15} \mathrm{Mn}_{0.05} \mathrm{O}_{2}$ & $\mathrm{LiNi}_{0.57} \mathrm{Co}_{0.15} \mathrm{Mn}_{0.28} \mathrm{O}_{2}$ & & & 11 & $50^{\circ} \mathrm{C}, 1000 \mathrm{rpm}$ & $750^{\circ} \mathrm{C} 20 \mathrm{hrs}(\mathrm{LiOH})$ & $15 \mu \mathrm{m}($ few $n \mathrm{~m}) / 15 \mu \mathrm{m}(\sim 1 \mu \mathrm{m})$ \\
\hline [107] & $\mathrm{LiNi}_{0.83} \mathrm{Co}_{0.07} \mathrm{Mn}_{0.10} \mathrm{O}_{2}(4)$ & $\mathrm{LiNi}_{0.86} \mathrm{Co}_{0.05} \mathrm{Mn}_{0.09} \mathrm{O}_{2}$ & $\mathrm{LiNi}_{0.68} \mathrm{Co}_{0.12} \mathrm{Mn}_{0.20} \mathrm{O}_{2}$ & $4 \mathrm{~L}$ & $2 \mathrm{~mol} / \mathrm{L}$ & & $\mathrm{N}_{2}$ & $730^{\circ} \mathrm{C} 15 \mathrm{hrs}(\mathrm{LiOH})$ & $12 \mu \mathrm{m}($ few $\mathrm{nm}) / 12 \mu \mathrm{m}(<0.5 \mu \mathrm{m})$ \\
\hline [104] & $\mathrm{LiNi}_{0.75} \mathrm{Co}_{0.10} \mathrm{Mn}_{0.15} \mathrm{O}_{2}(5)$ & $\mathrm{LiNi}_{0.70} \mathrm{Co}_{0.10} \mathrm{Mn}_{0.20} \mathrm{O}_{2}$ & $\mathrm{LiNi}_{0.86} \mathrm{Co}_{0.10} \mathrm{Mn}_{0.04} \mathrm{O}_{2}$ & & & & & $750^{\circ} \mathrm{C} 20 \mathrm{hrs}(\mathrm{LiOH})$ & $12 \mu \mathrm{m} / 10 \mu \mathrm{m}$ \\
\hline [108] & $\mathrm{LiNi}_{0.54} \mathrm{CO}_{0.16} \mathrm{Mn}_{0.30} \mathrm{C}_{2}(6)$ & $\mathrm{LiNi}_{0.66} \mathrm{CO}_{0.04} \mathrm{Mn}_{0.30} \mathrm{O}_{2}$ & $\mathrm{LiNi}_{0.51} \mathrm{CO}_{0.19} \mathrm{Mn}_{0.30} \mathrm{O}_{2}$ & $4 \mathrm{~L}$ & $4 \mathrm{~mol} / \mathrm{L} \mathrm{NaOH}$ & & $\mathrm{N}_{2}$ & $875^{\circ} \mathrm{C} 10 \mathrm{hrs}(\mathrm{LiOH})$ & $12 \mu \mathrm{m}(1-3 \mu \mathrm{m})$ \\
\hline [109] & $\begin{array}{l}\mathrm{LiNi}_{0.64} \mathrm{Co}_{0.16} \mathrm{Mn}_{0.22} \mathrm{O}_{2}(7) \\
\mathrm{LiNi}_{0.59} \mathrm{Co}_{0.16} \mathrm{Mn}_{0.25} \mathrm{O}_{2}(8) \\
\mathrm{LiNi}_{0.51} \mathrm{Co}_{0.16} \mathrm{Mn}_{0.33} \mathrm{O}_{2}(9)\end{array}$ & $\begin{array}{l}\mathrm{LiNi}_{0.75} \mathrm{CO}_{0.05} \mathrm{Mn}_{0.20} \mathrm{O}_{2} \\
\mathrm{LiNi}_{0.77} \mathrm{Co}_{0.05} \mathrm{Mn}_{0.25} \mathrm{O}_{2} \\
\mathrm{LiNi}_{0.62} \mathrm{Co}_{0.05} \mathrm{Mn}_{0.33} \mathrm{O}_{2}\end{array}$ & 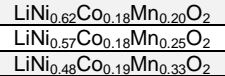 & $4 \mathrm{~L}$ & $3 \mathrm{~mol} / \mathrm{L} \mathrm{NaOH}$ & & $\mathrm{N}_{2}$ & $\begin{array}{l}780^{\circ} \mathrm{C} 10 \mathrm{hrs}(\mathrm{LiOH}) \\
845^{\circ} \mathrm{C} 10 \mathrm{hrs}(\mathrm{LiOH}) \\
920^{\circ} \mathrm{C} 10 \mathrm{hrs}(\mathrm{LiOH})\end{array}$ & $12 \mu \mathrm{m}(1-3 \mu \mathrm{m})$ \\
\hline [110] & $\mathrm{LiNi}_{0.60} \mathrm{Co}_{0.15} \mathrm{Mn}_{0.25} \mathrm{O}_{2}(10)$ & $\mathrm{LiNi}_{0.70} \mathrm{Co}_{0.10} \mathrm{Mn}_{0.20} \mathrm{O}_{2}$ & $\mathrm{LiNi}_{0.50} \mathrm{CO}_{0.20} \mathrm{Mn}_{0.30} \mathrm{O}_{2}$ & $4 \mathrm{~L}$ & $\begin{array}{c}2 \mathrm{~mol} / \mathrm{L} \\
4 \mathrm{~mol} / \mathrm{L} \mathrm{NaOH}\end{array}$ & 11.7 & $1000 \mathrm{rpm}, \mathrm{N}_{2}$ & $850^{\circ} \mathrm{C} 10$ hrs (LiOH) & $12 \mu \mathrm{m}(100-300 \mathrm{~nm}) / 12 \mu \mathrm{m}$ \\
\hline [111] & $\mathrm{LiNi}_{0.65} \mathrm{CO}_{0.08} \mathrm{Mn}_{0.27} \mathrm{O}_{2}(11)$ & $\mathrm{LiNi}_{0.89} \mathrm{CO}_{0.01} \mathrm{Mn}_{0.10} \mathrm{O}_{2}$ & $\mathrm{LiNi}_{0.61} \mathrm{Co}_{0.09} \mathrm{Mn}_{0.30} \mathrm{O}_{2}$ & & $4 \mathrm{~mol} / \mathrm{L} \mathrm{NaOH}$ & & $\mathrm{N}_{2}$ & $840^{\circ} \mathrm{C} 10 \mathrm{hrs}(\mathrm{LiOH})$ & $10 \mu \mathrm{m} / 10 \mu \mathrm{m}$ \\
\hline \multirow{3}{*}{ [112] } & $\mathrm{LiNi}_{0.60} \mathrm{Co}_{0.15} \mathrm{Mn}_{0.25} \mathrm{O}_{2}(10)$ & $\mathrm{LiNi}_{0.70} \mathrm{Co}_{0.05} \mathrm{Mn}_{0.25} \mathrm{O}_{2}$ & $\mathrm{LiNi}_{0.58} \mathrm{Co}_{0.17} \mathrm{Mn}_{0.25} \mathrm{O}_{2}$ & \multirow{3}{*}{$4 \mathrm{~L}$} & \multirow{3}{*}{$\begin{array}{c}1.2 \mathrm{~mol} / \mathrm{L} \\
4 \mathrm{~mol} / / \mathrm{NaOH} \\
2 \mathrm{~mol} / \mathrm{L} \mathrm{NH} \mathrm{NH}_{4} \mathrm{OH}\end{array}$} & & & $825^{\circ} \mathrm{C} 10$ hrs (LiOH) & \multirow{3}{*}{$12 \mu \mathrm{m}(1-3 \mu \mathrm{m})$} \\
\hline & $\mathrm{LiNi}_{0.59} \mathrm{Co}_{0.16} \mathrm{Mn}_{0.25} \mathrm{O}_{2}(8)$ & $\mathrm{LiNi}_{0.70} \mathrm{CO}_{0.05} \mathrm{Mn}_{0.25} \mathrm{O}_{2}$ & $\mathrm{LiNi}_{0.57} \mathrm{Co}_{0.18} \mathrm{Mn}_{0.25} \mathrm{O}_{2}$ & & & & & $845^{\circ} \mathrm{C} 10 \mathrm{hrs}(\mathrm{LiOH})$ & \\
\hline & $\mathrm{LiNi}_{0.56} \mathrm{CO}_{0.19} \mathrm{Mn}_{0.25} \mathrm{O}_{2}(12)$ & $\mathrm{LiNi}_{0.70} \mathrm{Co}_{0.05} \mathrm{Mn}_{0.25} \mathrm{O}_{2}$ & $\mathrm{LiNi}_{0.55} \mathrm{Co}_{0.20} \mathrm{Mn}_{0.25} \mathrm{O}_{2}$ & & & & & $875^{\circ} \mathrm{C} 10 \mathrm{hrs}(\mathrm{LiOH})$ & \\
\hline [113] & $\mathrm{LiNi}_{0.60} \mathrm{Co}_{0.20} \mathrm{Mn}_{0.20} \mathrm{O}_{2}(13)$ & $\mathrm{LiNi}_{0.72} \mathrm{Co}_{0.17} \mathrm{Mn}_{0.11} \mathrm{O}_{2}$ & $\mathrm{LiNi}_{0.61} \mathrm{Co}_{0.15} \mathrm{Mn}_{0.24} \mathrm{O}_{2}$ & $4 \mathrm{~L}$ & $2 \mathrm{~mol} / \mathrm{L}$ & 11.5 & $55^{\circ} \mathrm{C}, 1000 \mathrm{rpm}, \mathrm{N}_{2}$ & $500^{\circ} \mathrm{C} 10$ hrs $-\left(700,800,875^{\circ} \mathrm{C}\right) 15$ hrs (LiOH) & $10 \mu \mathrm{m}(<0.5 \mu \mathrm{m}) / 10 \mu \mathrm{m}(\sim 1 \mu \mathrm{m})$ \\
\hline [114] & $\mathrm{LiNi}_{0.65} \mathrm{CO}_{0.13} \mathrm{Mn}_{0.22} \mathrm{O}_{2}(14)$ & $\mathrm{LiNi}_{0.72} \mathrm{Co}_{0.11} \mathrm{Mn}_{0.17} \mathrm{O}_{2}$ & $\mathrm{LiNi}_{0.60} \mathrm{Co}_{0.12} \mathrm{Mn}_{0.28} \mathrm{O}_{2}$ & $40 \mathrm{~L}$ & $\begin{array}{l}4 \mathrm{~mol} / \mathrm{L} \mathrm{NaOH} \\
2 \mathrm{~mol} / \mathrm{L} \mathrm{NH} \mathrm{OH}_{4}\end{array}$ & & $\mathrm{~N}_{2}$ & $830^{\circ} \mathrm{C} 10$ hrs (LiOH) & \\
\hline [115] & $\mathrm{LiNi}_{0.8} \mathrm{Co}_{0.06} \mathrm{Mn}_{0.14} \mathrm{O}_{2}(15)$ & $\mathrm{LiNi}_{0.96} \mathrm{Co}_{0.01} \mathrm{Mn}_{0.03} \mathrm{O}_{2}$ & $\mathrm{LiNi}_{0.64} \mathrm{CO}_{0.06} \mathrm{Mn}_{0.30} \mathrm{O}_{2}$ & $40 \mathrm{~L}$ & $\begin{array}{r}4 \mathrm{~mol} / \mathrm{L} \mathrm{NaOH} \\
2 \mathrm{~mol} / \mathrm{NH} \mathrm{NH}_{4} \mathrm{OH}\end{array}$ & & $\mathrm{N}_{2}$ & $760^{\circ} \mathrm{C} 15$ hrs under $\mathrm{O}_{2}(\mathrm{LiOH})$ & $10 \mu \mathrm{m}(<0.5 \mu \mathrm{m}) / 10 \mu \mathrm{m}($ few nm) \\
\hline [116] & $\begin{array}{l}\frac{\mathrm{LiNi}_{0.333} \mathrm{Co}_{0.333} \mathrm{Mn}_{0.333} \mathrm{O}_{2}(16)}{\mathrm{LiNi}_{0.4} \mathrm{Co}_{0.2} \mathrm{Mn}_{0.4} \mathrm{O}_{2}(17)} \\
\mathrm{LiNi}_{0.416} \mathrm{Co}_{0.168} \mathrm{Mn}_{0.416} \mathrm{O}_{2}(18) \\
\mathrm{LiNi}_{0.45} \mathrm{Co}_{0.10} \mathrm{Mn}_{0.45} \mathrm{O}_{2}(19)\end{array}$ & $\begin{array}{l}\text { Riche en Co mais } \\
\text { pauvre en Li }\end{array}$ & $\begin{array}{l}\text { Riche en Li mais } \\
\text { pauvre en Co }\end{array}$ & & & 11 & $50^{\circ} \mathrm{C}, 1500 \mathrm{rpm}, \mathrm{N}_{2}$ & $950^{\circ} \mathrm{C} 16 \mathrm{hrs}\left(\mathrm{Li}_{2} \mathrm{CO}_{3}\right)$ & $\begin{array}{c}5-6 \mu \mathrm{m}(<0.5 \mu \mathrm{m}) / 5-6 \mu \mathrm{m}(1 \mu \mathrm{m}) \\
5-6 \mu \mathrm{m}(<0.5 \mu \mathrm{m}) / 5-6 \mu \mathrm{m}(1 \mu \mathrm{m}) \\
5-6 \mu \mathrm{m}(<0.5 \mu \mathrm{m}) / 5-6 \mu \mathrm{m}(1 \mu \mathrm{m}) \\
3-4 \mu \mathrm{m}(<0.5 \mu \mathrm{m}) / 3-4 \mu \mathrm{m}(1 \mu \mathrm{m})\end{array}$ \\
\hline [117] & $\mathrm{LiNi}_{0.85} \mathrm{Co}_{0.12} \mathrm{Mn}_{0.03} \mathrm{O}_{2}(20)$ & $\mathrm{LiNi}_{0.90} \mathrm{CO}_{0.10} \mathrm{O}_{2}$ & $\mathrm{LiNi}_{0.60} \mathrm{Co}_{0.25} \mathrm{Mn}_{0.15} \mathrm{O}_{2}$ & & $\begin{array}{c}1.5 \mathrm{~mol} / \mathrm{L} \\
3 \mathrm{~mol} / \mathrm{L} \mathrm{NaOH} \\
2 \mathrm{~mol} / \mathrm{L} \mathrm{NH} \mathrm{NH}_{4} \\
\end{array}$ & 11.5 & $50^{\circ} \mathrm{C}, 600 \mathrm{rpm}, \mathrm{N}_{2}$ & $550^{\circ} \mathrm{C} 4 \mathrm{hrs}-750^{\circ} \mathrm{C} 12 \mathrm{hrs}(\mathrm{LiOH})$ & $\begin{array}{l}5-17 \mu \mathrm{m}(\text { few } n m) / \\
5-17 \mu \mathrm{m}(<0.5 \mu \mathrm{m})\end{array}$ \\
\hline [118] & $\mathrm{LiNi}_{0.80} \mathrm{Co}_{0.10} \mathrm{Mn}_{0.10} \mathrm{O}_{2}(21)$ & $\mathrm{LiNi}_{0.6} \mathrm{Co}_{0.2} \mathrm{Mn}_{0.2} \mathrm{O}_{2}$ & $\mathrm{LiNiO}_{2}$ & & $\begin{array}{c}1.5 \mathrm{~mol} / \mathrm{L} \\
4 \mathrm{~mol} / \mathrm{L} \mathrm{NaOH} \\
2 \mathrm{~mol} / \mathrm{L} \mathrm{NH} \mathrm{NH}_{4}\end{array}$ & 11.5 & $50^{\circ} \mathrm{C}, 750 \mathrm{rpm}, \mathrm{N}_{2}$ & $550^{\circ} \mathrm{C} 4 \mathrm{hrs}-750^{\circ} \mathrm{C} 12 \mathrm{hrs}(\mathrm{LiOH})$ & $\begin{array}{l}8-12 \mu \mathrm{m}(\text { few } n \mathrm{~m}) / \\
8-12 \mu \mathrm{m}(<0.5 \mu \mathrm{m}) \\
\end{array}$ \\
\hline [119] & $\mathrm{LiNi}_{0.60} \mathrm{Co}_{0.20} \mathrm{Mn}_{0.20} \mathrm{O}_{2}(13)$ & $\mathrm{LiNi}_{0.83} \mathrm{Co}_{0.17} \mathrm{O}_{2}$ & $\mathrm{LiNi}_{0.22} \mathrm{Co}_{0.17} \mathrm{Mn}_{0.60} \mathrm{O}_{2}$ & $10 \mathrm{~L}$ & $4 \mathrm{~mol} / \mathrm{L} \mathrm{NaOH}$ & & $\mathrm{N}_{2}$ & $550^{\circ} \mathrm{C} 4 \mathrm{hrs}-820^{\circ} \mathrm{C} 12 \mathrm{hrs}$ under $\mathrm{O}_{2}(\mathrm{LiOH})$ & $10 \mu \mathrm{m}(<1 \mu \mathrm{m}) / 10 \mu \mathrm{m}(\sim 1 \mu \mathrm{m})$ \\
\hline [120] & $\mathrm{LiNi}_{0.70} \mathrm{Co}_{0.10} \mathrm{Mn}_{0.20} \mathrm{O}_{2}(22)$ & $\mathrm{LiNiO}_{2}$ & $\mathrm{LiNi}_{0.51} \mathrm{Co}_{0.16} \mathrm{Mn}_{0.33} \mathrm{O}_{2}$ & $10 \mathrm{~L}$ & $\begin{aligned} & 1.5 \mathrm{~mol} / \mathrm{L} \\
& 4 \mathrm{~mol} / \mathrm{L} \mathrm{NaOH} \\
&\end{aligned}$ & & $\mathrm{N}_{2}$ & $\begin{array}{c}550^{\circ} \mathrm{C} \text { 4hrs under air }-810^{\circ} \mathrm{C} 12 \mathrm{hrs} \text { under } \mathrm{O}_{2} \\
(\mathrm{LiOH})\end{array}$ & $10 \mu \mathrm{m}(0.5 \mu \mathrm{m}) / 10 \mu \mathrm{m}(0.5 \mu \mathrm{m})$ \\
\hline [121] * & $\mathrm{LiNi}_{0.60} \mathrm{Co}_{0.20} \mathrm{Mn}_{0.20} \mathrm{O}_{2}(13)$ & $\mathrm{LiNi}_{0.78} \mathrm{Mn}_{0.02} \mathrm{Co}_{0.20} \mathrm{O}_{2}$ & $\mathrm{LiNi}_{0.40} \mathrm{Co}_{0.20} \mathrm{Mn}_{0.38} \mathrm{O}_{2}$ & $10 \mathrm{~L}$ & $\begin{array}{c}2 \mathrm{~mol} / \mathrm{L} \\
10 \mathrm{~mol} / \mathrm{L} \mathrm{NaOH} 2 \\
\mathrm{~mol} / \mathrm{L} \mathrm{NH} \mathrm{NH}_{4} \mathrm{OH} \\
\end{array}$ & 11.6 & $50^{\circ} \mathrm{C}, 800 \mathrm{rpm}, \mathrm{N}_{2}$ & $800^{\circ} \mathrm{C} 16 \mathrm{hrs}(\mathrm{LiOH})$ & $10 \mu \mathrm{m}(<0.5 \mu \mathrm{m}) / 10 \mu \mathrm{m}(1 \mu \mathrm{m})$ \\
\hline [122] & $\mathrm{LiNi}_{0.50} \mathrm{Co}_{0.20} \mathrm{Mn}_{0.30} \mathrm{O}_{2}(23)$ & $\mathrm{LiNi}_{0.6} \mathrm{Co}_{0.2} \mathrm{Mn}_{0.2} \mathrm{O}_{2}$ & $\mathrm{LiNi}_{0.44} \mathrm{Co}_{0.2} \mathrm{Mn}_{0.36} \mathrm{O}_{2}$ & $170 \mathrm{~L}$ & $\begin{array}{c}2.5 \mathrm{~mol} / \mathrm{L} \\
10 \mathrm{~mol} / / \mathrm{NaOH} \\
1.5 \mathrm{~mol} / \mathrm{L} \mathrm{NH}{ }_{4} \mathrm{OH} \\
\end{array}$ & 11 & $50^{\circ} \mathrm{C}, 500 \mathrm{rpm}, \mathrm{N}_{2}$ & $750^{\circ} \mathrm{C}-900^{\circ} \mathrm{C}\left(\mathrm{Li}_{2} \mathrm{CO}_{3}\right)$ & $10 \mu \mathrm{m}(0.5 \mu \mathrm{m}) / 10 \mu \mathrm{m}(0.5 \mu \mathrm{m})$ \\
\hline [123] & $\mathrm{LiNi}_{0.50} \mathrm{Co}_{0.20} \mathrm{Mn}_{0.30} \mathrm{O}_{2}(23)$ & $\mathrm{LiNi}_{0.60} \mathrm{Co}_{0.20} \mathrm{Mn}_{0.20} \mathrm{O}_{2}$ & $\mathrm{LiNi}_{0.42} \mathrm{Co}_{0.20} \mathrm{Mn}_{0.38} \mathrm{O}_{2}$ & & $\begin{array}{c}2 \mathrm{~mol} / \mathrm{L} \\
1.5 \mathrm{~mol} / \mathrm{L} \mathrm{NH} \mathrm{OH}_{4} \mathrm{OH}\end{array}$ & $\sim 11.5$ & $600 \mathrm{rpm}$ & $900^{\circ} \mathrm{C} 2 \mathrm{hrs}-800^{\circ} \mathrm{C} 10 \mathrm{hrs}\left(\mathrm{Li}_{2} \mathrm{CO}_{3}\right)$ & $10 \mu \mathrm{m}(0.5 \mu \mathrm{m})$ \\
\hline [124] & $\mathrm{LiNi}_{0.62} \mathrm{Co}_{0.14} \mathrm{Mn}_{0.24} \mathrm{O}_{2}(24)$ & $\mathrm{LiNi}_{0.8} \mathrm{Co}_{0.2} \mathrm{O}_{2}$ & $\mathrm{LiNi}_{0.2} \mathrm{Mn}_{0.8} \mathrm{O}_{2}$ & & $\begin{array}{c}2 \mathrm{~mol} / \mathrm{L} \\
2 \mathrm{~mol} / \mathrm{L} \mathrm{NaOH} \\
0.5 \mathrm{~mol} / / \mathrm{N} \mathrm{NH} \mathrm{HH}_{4} \mathrm{OH} \\
\end{array}$ & 11 & $\mathrm{~N}_{2}$ & $800^{\circ} \mathrm{C} 15 \mathrm{hrs}(\mathrm{LiOH})$ & $3 \mu \mathrm{m}(\sim 0.5 \mu \mathrm{m})$ \\
\hline [125] & $\mathrm{LiNi}_{0.73} \mathrm{Co}_{0.12} \mathrm{Mn}_{0.15} \mathrm{O}_{2}(25)$ & $\mathrm{LiNi}_{0.8} \mathrm{CO}_{0.1} \mathrm{Mn}_{0.1} \mathrm{O}_{2}$ & $\mathrm{LiNi}_{0.4} \mathrm{Co}_{0.2} \mathrm{Mn}_{0.4} \mathrm{O}_{2}$ & & & 11 & $\mathrm{~N}_{2}$ & $480^{\circ} \mathrm{C} 5 \mathrm{hrs}-750^{\circ} \mathrm{C} 20 \mathrm{hrs}(\mathrm{LiOH})$ & $12 \mu \mathrm{m}(100-200 \mathrm{~nm})$ \\
\hline
\end{tabular}

* Feeding rates of the precursors $0.8 \mathrm{~L} / \mathrm{hrs}$ for $(\mathrm{Ni}, \mathrm{Co}) \mathrm{SO}_{4}$ and $0.4 \mathrm{~L} / \mathrm{hrs}$ for $(\mathrm{Ni}, \mathrm{Co}, \mathrm{Mn}) \mathrm{SO}_{4}$ 
Table II: Summary of the conditions used to prepare concentration gradients of layered oxides rich in nickel, as reported in patents available in English

\begin{tabular}{|c|c|c|c|c|c|c|c|c|c|c|}
\hline Reference & $\begin{array}{l}\text { Average composition } \\
\text { (reported as a number in } \\
\text { Figure 13) }\end{array}$ & Bulk composition & Surface composition & $\begin{array}{c}\text { Tank } \\
\text { volume } \\
\text { (L) }\end{array}$ & $\begin{array}{c}\text { Concentrations of } \\
\text { the transition } \\
\text { metal solution } \\
\text { and of the basic } \\
\text { solutions } \\
\end{array}$ & $\begin{array}{l}\text { Feeding rate of } \\
\text { solutions (L/hr) }\end{array}$ & $\mathrm{pH}$ & $\begin{array}{l}\text { Stirring conditions } \\
\text { (temperature, speed. } \\
\text { atmosphere) }\end{array}$ & $\begin{array}{c}\text { Calcination } \\
\text { T( }{ }^{\circ} \text { ) t(hrs) } \\
\text { (Lithium precursor) }\end{array}$ & $\begin{array}{l}\text { Size of the } \\
\text { aggregates (primary } \\
\text { particles) in the } \\
\text { intermediate } \\
\text { precursor / oxide }\end{array}$ \\
\hline \multirow{3}{*}{ [126] } & $\mathrm{LiNi}_{0.64} \mathrm{Co}_{0.24} \mathrm{Mn}_{0.12} \mathrm{O}_{2}(26)$ & $\mathrm{LiNi}_{0.80} \mathrm{CO}_{0.13} \mathrm{Mn}_{0.07} \mathrm{O}_{2}$ & $\mathrm{LiNi}_{0.40} \mathrm{Co}_{0.40} \mathrm{Mn}_{0.20} \mathrm{O}_{2}$ & \multirow{3}{*}{$4 \mathrm{~L}$} & \multirow{3}{*}{$2.4 \mathrm{mo} / \mathrm{L}$} & \multirow{3}{*}{$\begin{array}{l}0.3 \mathrm{~L} / \mathrm{hr} \text { (sulfates) } \\
0.03 \mathrm{~L} / \mathrm{hr}\left(\mathrm{NH}_{4} \mathrm{OH}\right)\end{array}$} & \multirow{3}{*}{11} & \multirow{3}{*}{$50^{\circ} \mathrm{C}, 1000 \mathrm{rpm}, \mathrm{N}_{2}$} & \multirow{3}{*}{$\begin{array}{c}500^{\circ} \mathrm{C}, 1 \text { hohrs }-780^{\circ} \mathrm{C} \\
20 \text { hrs (LiOH) }\end{array}$} & \multirow{3}{*}{$10-30 \mu \mathrm{m} / 10-30 \mu \mathrm{m}$} \\
\hline & LiNi $\mathrm{Li}_{0.71} \mathrm{CO}_{0.13} \mathrm{Mn}_{0.16} \mathrm{O}_{2}(27)$ & $\mathrm{LiNi}_{0.80} \mathrm{C}_{0.10} \mathrm{Mn}_{0.10} \mathrm{O}_{2}$ & $\mathrm{LiNi}_{0.50} \mathrm{CO}_{0.20} \mathrm{Mn}_{0.30} \mathrm{O}_{2}$ & & & & & & & \\
\hline & $\mathrm{LiNi}_{0.70} \mathrm{Co}_{0.08} \mathrm{Mn}_{0.22} \mathrm{O}_{2}(28)$ & $\mathrm{LiNi}^{2} \mathrm{LiNi.80}_{0.80} \mathrm{Co}_{0.11} \mathrm{Cu}_{0.13} \mathrm{Mn}_{0.05} \mathrm{Al}_{0.05} \mathrm{O}_{2}$ & 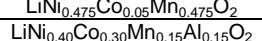 & & & & & & & \\
\hline \multirow{5}{*}{ [127] } & & $\mathrm{LiNi}_{0.85} \mathrm{CO}_{0.10} \mathrm{Mn}_{0.05} \mathrm{O}_{2}$ & $\mathrm{LiNi}_{0.60} \mathrm{Co}_{0.1} \mathrm{Mn}_{0,30} \mathrm{O}_{2}$ & \multirow{5}{*}{$4 \mathrm{~L}$} & \multirow{5}{*}{$\begin{array}{c}2.4 \mathrm{~mol} / \mathrm{L} \\
4.8 \mathrm{~mol} / \mathrm{NaOH} \\
3.6 \mathrm{~mol} / \mathrm{N} \mathrm{NH}{ }_{4} \mathrm{OH}\end{array}$} & \multirow{5}{*}{$\begin{array}{l}0.3 \mathrm{~L} / \mathrm{hr} \text { (sulfates) } \\
0.03 \mathrm{~L} / \mathrm{hr}\left(\mathrm{NH}_{4} \mathrm{OH}\right)\end{array}$} & \multirow{5}{*}{11} & \multirow{5}{*}{$50^{\circ} \mathrm{C}, 1000 \mathrm{rpm}, \mathrm{N}_{2}$} & \multirow{5}{*}{$\begin{array}{c}280^{\circ} \mathrm{C} 10 \mathrm{hrs}-750^{\circ} \mathrm{C} \\
15 \mathrm{hrs}\left(\mathrm{LiNO}_{3}\right)\end{array}$} & \multirow{5}{*}{$12 \mu \mathrm{m}$} \\
\hline & & LiNio. $.85 \mathrm{Co}_{0.10} \mathrm{Mn}_{0.25} \mathrm{O}_{2}$ & $\mathrm{LiNi}_{0.70} \mathrm{Co}_{0.08} \mathrm{Mn}_{0.22} \mathrm{O}_{2}$ & & & & & & & \\
\hline & & $\mathrm{LiNi}_{0.85} \mathrm{CO}_{0.10} \mathrm{Mn}_{0.05} \mathrm{O}_{2}$ & $\mathrm{LiNi}_{0.70} \mathrm{CO}_{0.05} \mathrm{Mn}_{0.25} \mathrm{O}_{2}$ & & & & & & & \\
\hline & & $\frac{\mathrm{LiNi}_{0.77} \mathrm{CO}_{0.1010} \mathrm{Mn}_{0.02} \mathrm{O}_{2}}{\mathrm{LiNi}_{0.80} \mathrm{Co}_{0,10} \mathrm{Mn}_{0.10} \mathrm{O}_{2}}$ & $\frac{\mathrm{LiNi}_{0.80} \mathrm{CO}_{0.05} \mathrm{Mn}_{0.15} \mathrm{O}_{2}}{\mathrm{Lini}}$ & & & & & & & \\
\hline & & LiNi & LiNi. & & & & & & & \\
\hline \multirow{5}{*}{ [128] } & $\mathrm{LiNi}_{0.80} \mathrm{Co}_{0.07} \mathrm{Mn}_{0.13} \mathrm{O}_{2}(29)$ & $\mathrm{LiNi}_{0.80} \mathrm{Co}_{0.10} \mathrm{Mn}_{0.10} \mathrm{O}_{2}$ & $\mathrm{LiNi}_{0.80} \mathrm{Mn}_{0.22} \mathrm{O}_{2}$ & \multirow{3}{*}{$4 \mathrm{~L}$} & \multirow{3}{*}{$\begin{array}{l}2.4 \mathrm{~mol} / \mathrm{L} \\
4.8 \mathrm{~mol} / \mathrm{NaOH} \\
3.6 \mathrm{~mol} / \mathrm{L} \mathrm{NH} \mathrm{NH}_{4} \mathrm{OH}\end{array}$} & \multirow{3}{*}{$\begin{array}{c}0.3 \mathrm{~L} / \mathrm{hr} \text { (sulfates) } \\
0.03 \mathrm{~L} / \mathrm{hr}\left(\mathrm{NH}_{4} \mathrm{OH}\right)\end{array}$} & \multirow{5}{*}{11} & \multirow{3}{*}{$50^{\circ} \mathrm{C}, 1000 \mathrm{rpm}, \mathrm{N}_{2}$} & \multirow{5}{*}{$\begin{array}{c}280^{\circ} \mathrm{C} 10 \mathrm{hrs}-750^{\circ} \mathrm{C} \\
15 \mathrm{hrs}\left(\mathrm{LiNO}_{3}\right)\end{array}$} & \multirow{5}{*}{$\begin{array}{l}12 \mu \mathrm{m}(\text { few } \mathrm{nm}) / \\
12 \mu \mathrm{m}(\sim 1 \mu \mathrm{m})\end{array}$} \\
\hline & LiNi ${ }_{0.75} \mathrm{Co}_{0.07} \mathrm{Mn}_{0.18} \mathrm{O}_{2}(30)$ & $\mathrm{LiNi}_{0.75} \mathrm{Co}_{0.125} \mathrm{Mn}_{0.125} \mathrm{O}_{2}$ & $\mathrm{LiNi}_{0.75} \mathrm{Mn}_{0.25} \mathrm{O}_{2}$ & & & & & & & \\
\hline & LiNi & $\mathrm{LiNi}_{0.70} \mathrm{Co}_{0.15} \mathrm{Mn}_{0.15} \mathrm{O}_{2}$ & $\mathrm{LiN \textrm {N } _ { 0 . 7 0 } \mathrm { Mn } _ { 0 . 3 0 } \mathrm { O } _ { 2 }}$ & & & & & & & \\
\hline & 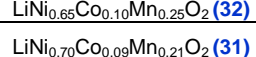 & $\begin{array}{l}\mathrm{LiNi}_{0.65} \mathrm{C}_{0.175} \mathrm{Mn}_{0.175} \mathrm{O}_{2} \\
\mathrm{LiNi}^{-7.70} \mathrm{Co}_{0.15} \mathrm{Mn}_{0.15} \mathrm{O}_{2}\end{array}$ & $\begin{array}{l}\mathrm{LiNi}_{0.65} \mathrm{Mn}_{0.35} \mathrm{O}_{2} \\
\mathrm{LiNi} \mathrm{Mn}_{3} \mathrm{O}_{2}\end{array}$ & 8L & $10 \mathrm{~mol} / \mathrm{L} \mathrm{NaOH}$ & $0.2 \mathrm{~L} / \mathrm{hr}$ (sulfates) & & $50^{\circ} \mathrm{C}, 450 \mathrm{rpm}, \mathrm{N}_{2}$ & & \\
\hline & $\mathrm{LiNi}_{0.72} \mathrm{Co}_{0.10} \mathrm{Mn}_{0.18} \mathrm{O}_{2}(33)$ & $\mathrm{LiNi}_{0.90} \mathrm{CO}_{0.10} \mathrm{O}_{2}$ & $\mathrm{LiNi}_{0.70} \mathrm{Co}_{0.10} \mathrm{Mn}_{0.30} \mathrm{O}_{2}$ & $4 \mathrm{~L}$ & $\begin{array}{l}4.8 \mathrm{~mol} / \mathrm{NH} \mathrm{NH}_{4} \mathrm{OH} \\
4.4 \mathrm{mo} / \mathrm{L} / \mathrm{NaOH} \\
3.6 \mathrm{~mol} / \mathrm{L} \mathrm{NH} \mathrm{NH}_{4} \mathrm{OH}\end{array}$ & $\begin{array}{l}0.3 \mathrm{~L} / \mathrm{hr} \text { (sulfates) } \\
0.03 \mathrm{~L} / \mathrm{hr}\left(\mathrm{NH}_{4} \mathrm{OH}\right)\end{array}$ & & $50^{\circ} \mathrm{C}, 1000 \mathrm{rpm}, \mathrm{N}_{2}$ & & \\
\hline [129] & & $\frac{\mathrm{LiNi}_{0.88} \mathrm{CO}_{0.050} \mathrm{Mn}_{0.07} \mathrm{O}_{2}}{\mathrm{LiNi}_{0.88} \mathrm{Co}_{0.50} \mathrm{Mn}_{0.07} \mathrm{O}_{2}}$ & $\frac{\mathrm{LiNi}_{0.52} \mathrm{CO}_{0.16} \mathrm{Mn}_{0.32} \mathrm{O}_{2}}{\mathrm{LiNi}_{0.60} \mathrm{CO}_{0.12} \mathrm{Mn}_{0.28} \mathrm{O}_{2}}$ & $4 \mathrm{~L}$ & & $\begin{array}{l}0.3 \mathrm{~L} / \mathrm{hr} \text { (sulfates) } \\
0.3 \mathrm{~L} / \mathrm{hr}\left(\mathrm{NH}_{4} \mathrm{OH}\right)\end{array}$ & & $50^{\circ} \mathrm{C}, 1000 \mathrm{rpm}, \mathrm{N}_{2}$ & \multirow{2}{*}{$\begin{array}{c}450^{\circ} \mathrm{C} \text { 5hrs }-820^{\circ} \mathrm{C} \\
10 \mathrm{hrs}(\mathrm{LiOH}) \\
550^{\circ} \mathrm{C} 10 \mathrm{hrs}-750^{\circ} \mathrm{C}\end{array}$} & \multirow[b]{2}{*}{ 8-13 $\mu \mathrm{m}$} \\
\hline [130] & & $\mathrm{LiNi}_{0.65} \mathrm{Co}_{0.1} \mathrm{Mn}_{0.25} \mathrm{O}_{2}$ & $\mathrm{LiNi}_{0.4} \mathrm{Co}_{0.1} \mathrm{Mn}_{0.5} \mathrm{O}_{2}$ & $70 \mathrm{~L}$ & $2.5 \mathrm{~mol} / \mathrm{L}$ & $\begin{array}{l}6.9 \mathrm{~L} / \mathrm{hr} \text { (sulfates) } \\
0.48 \mathrm{~L} / \mathrm{hr}\left(\mathrm{NH}_{4} \mathrm{OH}\right)\end{array}$ & 11 & $50^{\circ} \mathrm{C}, 400 \mathrm{rpm}$ & & \\
\hline [131] & $\mathrm{LiNi}_{0.80} \mathrm{Co}_{0.10} \mathrm{Mn}_{0.10} \mathrm{O}_{2}(21)$ & $\mathrm{LiNi}_{0.84} \mathrm{Co}_{0.11} \mathrm{Mn}_{0.05} \mathrm{O}_{2}$ & $\mathrm{LiNi}_{0.78} \mathrm{CO}_{0.10} \mathrm{Mn}_{0.12} \mathrm{O}_{2}$ & & & & & & & $10 \mu \mathrm{m}$ \\
\hline
\end{tabular}

Table III: Summary of the conditions used to prepare concentration gradients of layered oxides rich in manganese, as reported in literature

\begin{tabular}{|c|c|c|c|c|c|c|c|c|c|}
\hline Reference & $\begin{array}{l}\text { Average composition (reported } \\
\text { as a number in Figure 13) }\end{array}$ & Bulk composition & Surface composition & $\begin{array}{l}\text { Concentrations of } \\
\text { the transition } \\
\text { metal sulfate } \\
\text { solution and of } \\
\text { the basic } \\
\text { solutions }\end{array}$ & $\begin{array}{l}\text { Feeding } \\
\text { rate of } \\
\text { solutions } \\
\text { (L/hr) }\end{array}$ & $\mathrm{pH}$ & $\begin{array}{l}\text { Stirring conditions } \\
\text { (temperature, speed. } \\
\text { atmosphere) }\end{array}$ & $\begin{array}{l}\text { Calcination } \\
\mathrm{T}\left({ }^{\circ} \mathrm{C}\right) \mathrm{t}(\mathrm{hrs}) \\
\text { (Lithium } \\
\text { precursor) }\end{array}$ & $\begin{array}{l}\text { Size of the aggregates (primary } \\
\text { particles) in the intermediate } \\
\text { precursor / oxide }\end{array}$ \\
\hline [132] & $\mathrm{Li}_{1.2}\left(\mathrm{Mn}_{0.62} \mathrm{Ni}_{0.38}\right)_{0.8} \mathrm{O}_{2}(34)$ & $\mathrm{Li}_{1.2}\left(\mathrm{Mn}_{0.37} \mathrm{Ni}_{0.63}\right)_{0.8} \mathrm{O}_{2}$ & $\mathrm{Li}_{1.2}\left(\mathrm{Mn}_{0.62} \mathrm{Ni}_{0.38}\right)_{0.8} \mathrm{O}_{2}$ & $\begin{array}{c}2 \mathrm{~mol} / \mathrm{L} \\
2 \mathrm{~mol} / / \mathrm{L} / \mathrm{Na}_{2} \mathrm{CO}_{3} \\
0.2 \mathrm{~mol} / \mathrm{NH} \mathrm{OH}_{4} \mathrm{OH}\end{array}$ & $1 \mathrm{~L} / \mathrm{h}$ & 8 & $60^{\circ} \mathrm{C}, 500 \mathrm{rpm}$ & $\begin{array}{c}600^{\circ} \mathrm{C} 15 \mathrm{hrs} \\
900^{\circ} \mathrm{C} 15 \mathrm{hrs} \\
\left(\mathrm{LiCO}_{3}\right) \\
\end{array}$ & $20 \mu \mathrm{m} / 15 \mu \mathrm{m}(<0.5 \mu \mathrm{m})$ \\
\hline [133] & $\mathrm{Li}_{1.13}\left(\mathrm{Ni}_{0.233} \mathrm{Co}_{0.233} \mathrm{Mn}_{0.534}\right)_{0.87} \mathrm{O}_{2}(35)$ & $\mathrm{Li}_{1.13}\left(\mathrm{Ni}_{0.32} \mathrm{Co}_{0.31} \mathrm{Mn}_{0.37}\right)_{0.87} \mathrm{O}_{2}$ & $\mathrm{Li}_{1.13}\left(\mathrm{Ni}_{0.27} \mathrm{CO}_{0.25} \mathrm{Mn}_{0.48}\right)_{0.87} \mathrm{O}_{2}$ & & & & & $\begin{array}{c}500^{\circ} \mathrm{C} \text { 8hrs } \\
900^{\circ} \mathrm{C} 10 \mathrm{hrs} \\
\left(\mathrm{Li}_{2} \mathrm{CO}_{3}\right)\end{array}$ & $10 \mu \mathrm{m}($ few nm) / $10 \mu \mathrm{m}(\sim 1 \mu \mathrm{m})$ \\
\hline [134] & $\mathrm{Li}_{1.14}\left(\mathrm{Ni}_{0.25} \mathrm{Co}_{0.15} \mathrm{Mn}_{0.60}\right)_{0.86} \mathrm{O}_{2}(36)$ & $\mathrm{Li}_{1.14}\left(\mathrm{Ni}_{0.25} \mathrm{Co}_{0.50} \mathrm{Mn}_{0.25}\right)_{0.86} \mathrm{O}_{2}$ & $\mathrm{Li}_{1.14}\left(\mathrm{Ni}_{0.25} \mathrm{Co}_{0.10} \mathrm{Mn}_{0.65}\right)_{0.86} \mathrm{O}_{2}$ & $\begin{array}{c}1.5 \mathrm{~mol} / \mathrm{L} \\
1.5 \mathrm{~mol} / / \mathrm{L} \mathrm{Na} \\
\mathrm{CO}_{3}\end{array}$ & & 7.5 & $55^{\circ} \mathrm{C}, 800 \mathrm{rpm}$ & $\begin{array}{l}500^{\circ} \mathrm{C} 8 \mathrm{hrs} \\
900^{\circ} \mathrm{C} 16 \mathrm{hrs} \\
\left(\mathrm{Li}_{2} \mathrm{CO}_{3}\right)\end{array}$ & $8 \mu \mathrm{m}(\mathrm{few} \mathrm{nm}) / 8 \mu \mathrm{m}(<0.5 \mu \mathrm{m})$ \\
\hline [135] & $\mathrm{Li}_{1.5} \mathrm{Mn}_{0.75} \mathrm{Ni}_{0.20} \mathrm{Mgg}_{0.05} \mathrm{O}_{2}$ & $\mathrm{Li}_{1.5} \mathrm{Mn}_{0.75} \mathrm{Ni}_{0.25} \mathrm{O}_{2}$ & $\mathrm{Li}_{1.5} \mathrm{Mn}_{0.75} \mathrm{Ni}_{0.10} \mathrm{Mg}_{0.15} \mathrm{O}_{2}$ & $\begin{array}{c}1.6 \mathrm{~mol} / \mathrm{L} \\
1.6 \mathrm{~mol} / \mathrm{L} \mathrm{Na}{ }_{2} \mathrm{CO}_{3}\end{array}$ & & 7.5 & $55^{\circ} \mathrm{C}, 600 \mathrm{rpm}$ & $\begin{array}{c}500^{\circ} \mathrm{C} \text { 6hrs } \\
850^{\circ} \mathrm{C} 12 \mathrm{hrs} \\
\left(\mathrm{Li}_{2} \mathrm{CO}_{3}\right) \\
\end{array}$ & $10 \mu \mathrm{m}(\mathrm{few} \mathrm{nm}) / 10 \mu \mathrm{m}(<0.5 \mu \mathrm{m})$ \\
\hline
\end{tabular}




\section{b). The attractive properties of the concentration gradients}

In the following we will highlight through a few examples taken from Y.K. Sun et al. how beneficial the preparation of concentration gradients - or at least of core-shells - can be. The first example chosen is the layered oxide of average composition $\mathrm{LiNi}_{0.64} \mathrm{Mn}_{0.18} \mathrm{Co}_{0.18} \mathrm{O}_{2}$ (1) with the composition $\mathrm{LiNi}_{0.8} \mathrm{Mn}_{0.1} \mathrm{Co}_{0.1} \mathrm{O}_{2}$ (NMC 811) in the core and the composition $\mathrm{LiNi}_{0.46} \mathrm{Mn}_{0.31} \mathrm{Co}_{0.23} \mathrm{O}_{2}$ (NMC 532) at the surface, and with thus a decrease in the Ni content from the bulk to the surface and reverse for Co and Mn as shown in Figure 14 [103]. The characterization of the extent of the gradient within the hydroxide intermediate and the final oxide is achieved through elemental quantitative analyses using electron-probe X-ray microanalysis (EPMA) of polished spherical aggregates. It is really critical as during the second step of the synthesis - i.e. the sintering of the mixed carbonate or hydroxide with the lithium precursor - a high temperature thermal treatment occurs (above $750^{\circ} \mathrm{C}$ ) inducing interdiffusion of the transition metals within the aggregates, as already revealed by different authors [112], [117], [119], [136]. A recent study performed by Li et al. has shown that interdiffusion between $\mathrm{Ni}^{3+} / \mathrm{Mn}^{4+}$ is the slowest even at high temperature $\mathrm{vs}^{3}{ }^{3+} / \mathrm{Co}^{3+}$ and even $\mathrm{Co}^{3+} / \mathrm{Mn}^{4+}$. [137] 

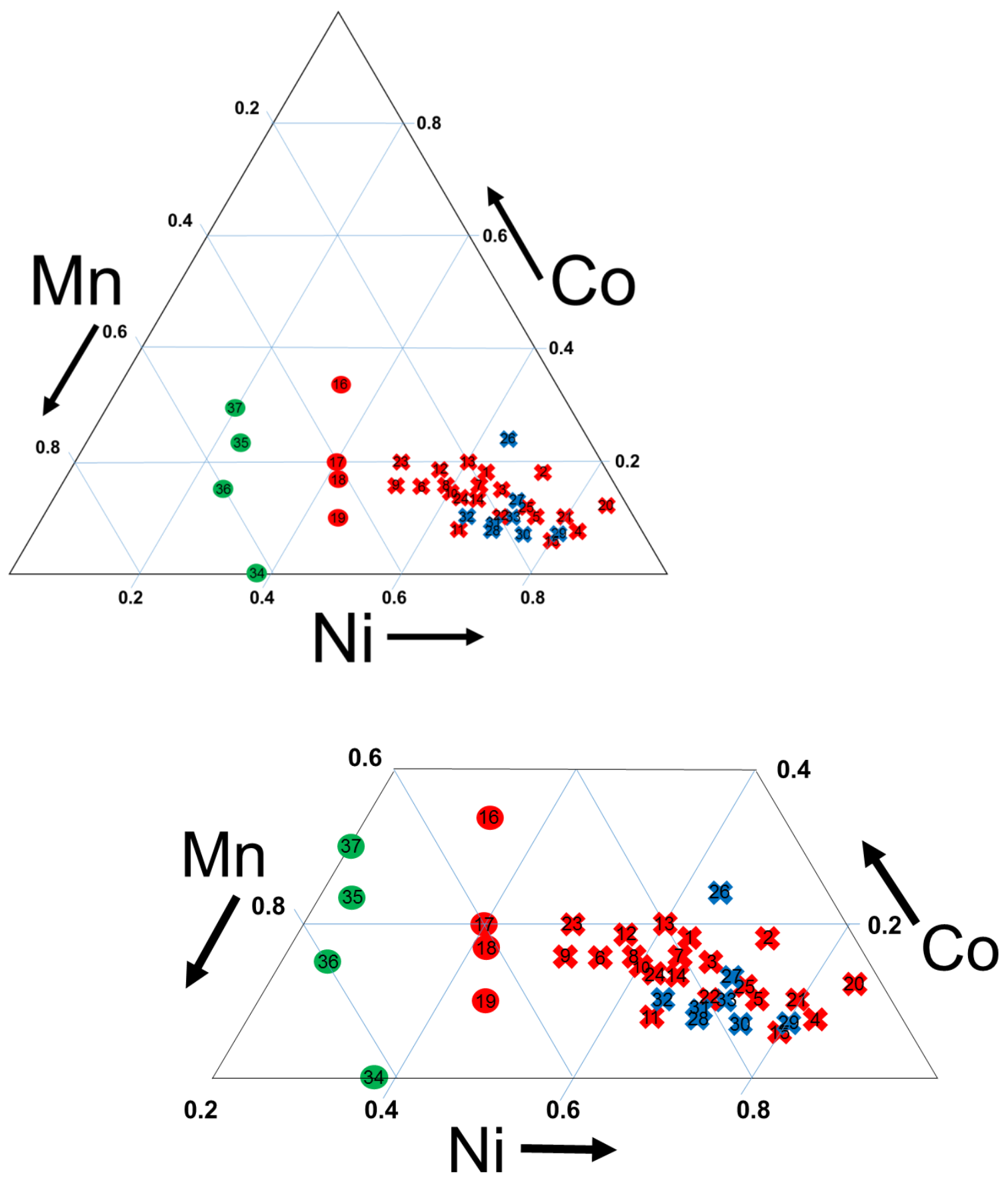

Figure 13: Phase diagram screened in the literature for the intermediate precursors rich in $\mathrm{Ni}, \mathrm{Mn}$ and Co. The crosses and circles correspond to hydroxides and carbonates respectively, whereas the red, blue and green colors are associated to the compositions gathered in the tables I, II and III respectively. The black numbers in the symbols used in this figure correspond to the red ones reported in the first columns of the three tables I, II and III.

In order to asset the benefic effect of the concentration gradients, the electrochemical behavior of different materials were compared in full cells, at $55^{\circ} \mathrm{C}$, a critical temperature to check for the stability and cyclability of the material (Figure 15): the compositions of the bulk 

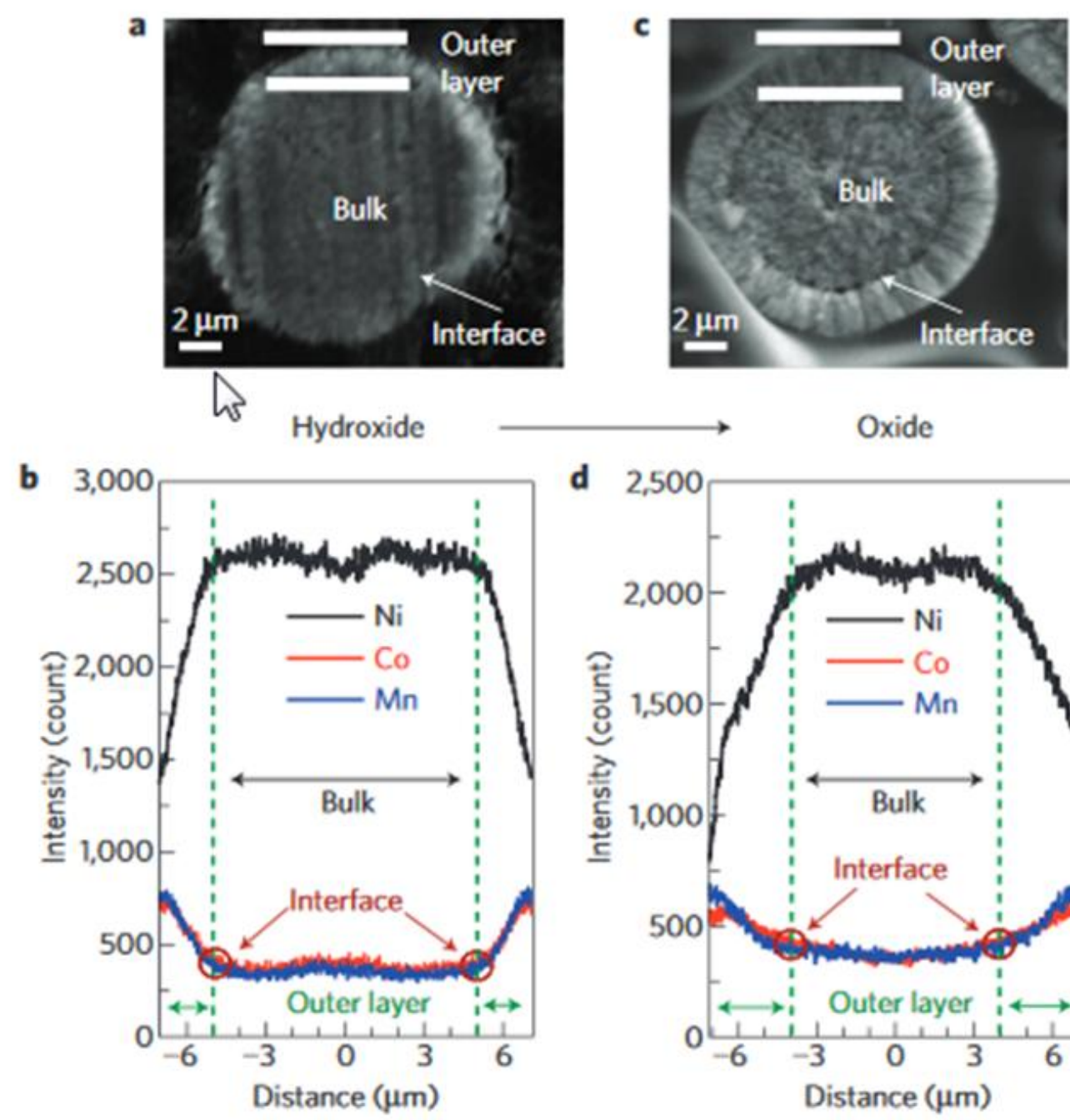


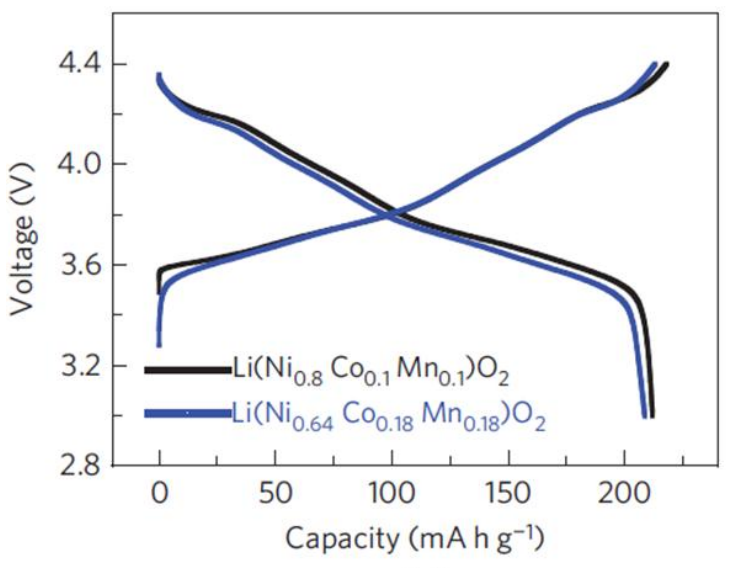

(a)

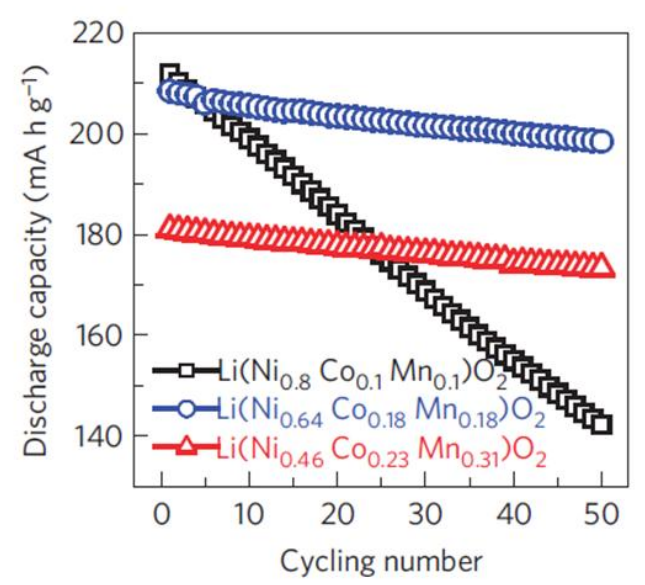

(b)

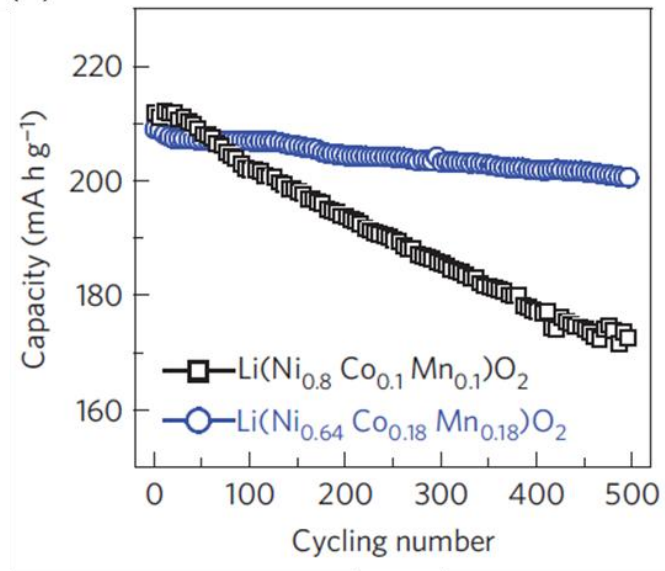

(c)

Figure 15: (a) Very similar electrochemical charge and discharge curves obtained during the $1^{\text {st }}$ cycle vs. $\mathrm{Li}^{+} / \mathrm{Li}$, at the rate of $\mathrm{C} / 2$ and $\underline{\text { at }} \mathbf{5 5}^{\circ} \mathbf{C}$, for $\mathrm{LiNi}_{0.8} \mathrm{Co}_{0.1} \mathrm{Mn}_{0.1} \mathrm{O}_{2}$ (the material in the bulk) and for the concentration gradient of average composition $\mathrm{LiNi}_{0.64} \mathrm{Co}_{0.18} \mathrm{Mn}_{0.18} \mathrm{O}_{2}$. (b) Changes in the reversible capacity observed upon cycling of $\mathrm{LiNi}_{0.8} \mathrm{Co}_{0.1} \mathrm{Mn}_{0.1} \mathrm{O}_{2}$ (the composition within the bulk), $\mathrm{LiNi}_{0.46} \mathrm{Co}_{0.23} \mathrm{Mn}_{0.31} \mathrm{O}_{2}$ (the composition at the surface) and $\mathrm{LiNi}_{0.64} \mathrm{Co}_{0.18} \mathrm{Mn}_{0.18} \mathrm{O}_{2}$ (the corresponding concentration gradient) in Lithium batteries, between 3 and $4.4 \mathrm{~V}$, at the rate of $\mathrm{C} / 2$ and at $55^{\circ} \mathrm{C}$. (c) Changes in the reversible capacity obtained at the rate of $1 \mathrm{C}$ (higher rate) in pouch-cells with mesoporous graphite at the negative electrode, and either $\mathrm{LiNi}_{0.8} \mathrm{Co}_{0.1} \mathrm{Mn}_{0.1} \mathrm{O}_{2}($ the composition of the bulk) or the concentration gradient at the positive electrode. The potential range is screened between 3 and $4.2 \mathrm{~V}$ vs. $\mathrm{Li}^{+} / \mathrm{Li}$. The electrolyte used is $1 \mathrm{M} \mathrm{LiPF}_{6}$ in a mixture of ethylene and diethyl carbonates (1:1 in volume) (Adapted from the reference [103]).

In fact, it is possible to tailor the gradient within a given composition domain limited by two extreme compositions, for the bulk and the surface and to tailor the properties. Indeed, in between, an infinity of average compositions exist and can be developed as concentration gradients. Recently, Lee 


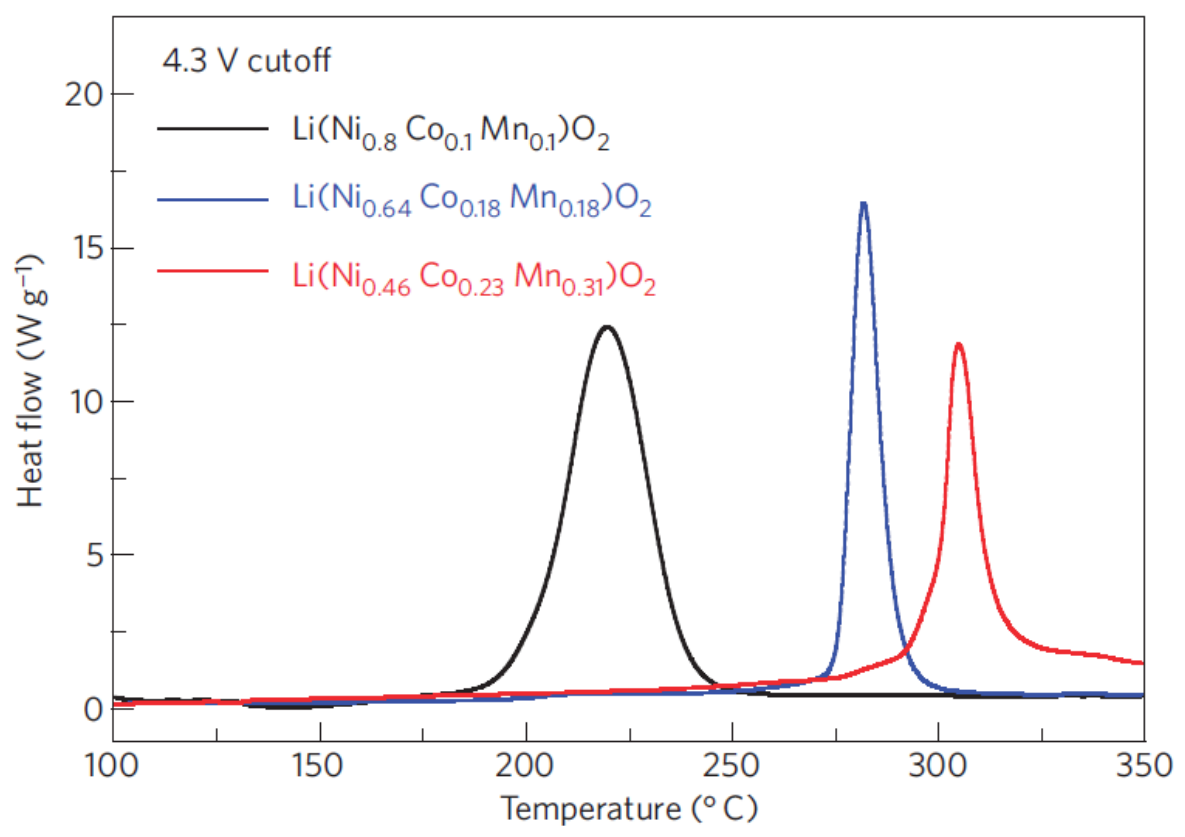

Figure 16: Comparison of the thermal stability of the de-intercalated materials recovered at $4.3 \mathrm{~V} \mathrm{vs}$. $\mathrm{Li}^{+} / \mathrm{Li}$, using differential scanning calorimetry analyses. The higher the heat flow the more exothermic is the degradation reaction of the material with the electrolyte $\left(1 \mathrm{M} \mathrm{LiPF} 6\right.$ EC/DEC (1:1)). The materials are $\mathrm{Li}_{1 \text { - }}$ ${ }_{\delta} \mathrm{Ni}_{0.8} \mathrm{Co}_{0.1} \mathrm{Mn}_{0.1} \mathrm{O}_{2}$ (the composition of the bulk), $\mathrm{Li}_{1-\delta} \mathrm{Ni}_{0.46} \mathrm{Co}_{0.28} \mathrm{Mn}_{0.31} \mathrm{O}_{2}$ (the composition at the surface) and $\mathrm{Li}_{1-\delta} \mathrm{Ni}_{0.64} \mathrm{Co}_{0.18} \mathrm{Mn}_{0.18} \mathrm{O}_{2}$ (the corresponding concentration gradient) (adapted from the reference [103]).

et al. [112] have for instance compared a series of concentration gradients such as $\mathrm{LiNi}_{0.6-}$ ${ }_{\mathrm{x}} \mathrm{Co}_{0.15+\mathrm{x}} \mathrm{Mn}_{0.25} \mathrm{O}_{2}$ (x = 0 (10), 0.01 (8) and 0.04 (12)). They have shown that the larger the contribution of the Mn-rich layered compositions, the worst are the performance at high rates and at low temperatures, as expected as the presence of $\mathrm{Mn}^{4+}$ in the host structure is detrimental to transport properties. Nevertheless, the formation of a surface richer in Mn contributes to the stabilization of the chemical stability and thermal stability of the deintercalated layered oxides obtained in the charge state of the batteries. As always, it appears that the optimized material is the result of compromises, which fit with the application targeted: a long range cycling high energy material will not be the best material to develop for power demanding and low temperature applications.

Only few strategies of material engineering have been applied to $\mathrm{Li}$ and $\mathrm{Mn}$-rich layered oxides, all of them with the presence of the Mn-richer composition at the surface of the composites. Yang et al. [134] have for 


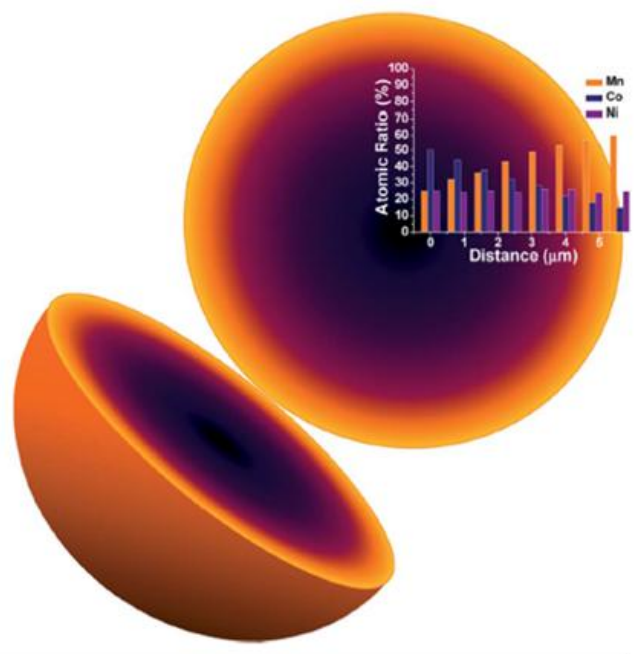

(a)

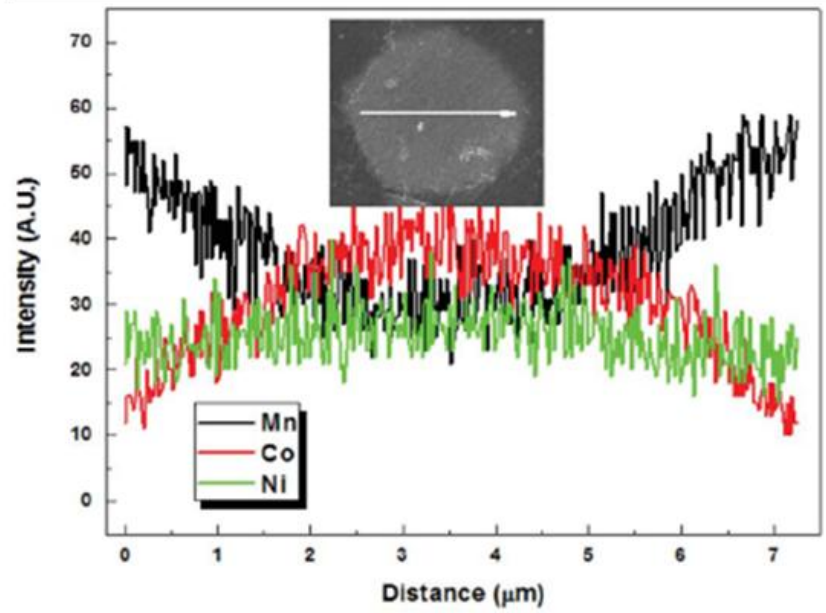

(b)

Figure 17: (a) Schematic representation of a spherical aggregate for a concentration gradient Li-rich layered oxide characterized by an average composition of $\mathrm{Li}_{1.14} \mathrm{Ni}_{0.25} \mathrm{Mn}_{0.60} \mathrm{Co}_{0.15} \mathrm{O}_{2}$. The theoretical change in the transition metal content is also given for Mn, Co and Ni. (b) EDX analyses of a polished agglomerate, which shows a decreasing concentration in Co from the core to the surface, and reverse for $\mathrm{Mn}$, the composition in $\mathrm{Ni}$ remaining constant (adapted from the reference [134]).

instance studied the concentration gradient of average composition $\mathrm{Li}_{1.14}\left(\mathrm{Ni}_{0.25} \mathrm{Co}_{0.15} \mathrm{Mn}_{0.60}\right)_{0.86} \mathrm{O}_{2}(36)$ which is as shown in Figure 17 richer in Co within the bulk and richer in Mn at the surface. The changes in the transition metal content is continuous over the entire radii of the aggregates, i.e. over $3.5 \mu \mathrm{m}$. This composite material delivers improved and very attractive performances versus those obtained for the corresponding homogeneous composition (i.e. a reversible capacity of $\sim 200 \mathrm{mAh} / \mathrm{g}(2-4.6 \mathrm{~V}, \mathrm{C} / 2)$ and a capacity retention of $93.8 \%$ after 200 cycles vs. a capacity decreasing from $200 \mathrm{mAh} / \mathrm{g}$ and a capacity retention of $66.3 \%$ for the homogeneous composition). The composite behaves as if the Mn-rich shell could effectively protect the $\mathrm{Ni}$ and $\mathrm{Co}$-rich core from degradation reactions with the electrolyte. The mechanisms involved are not obvious since the aggregates are porous with thus the possible penetration of the electrolyte within the pores and grain boundaries. The characterization of this porosity and of the wettability by the electrolyte are not that easy even if it would be interesting to come to that understanding. As revealed in Figure 18 the voltage signature is more stable upon cycling for the composite than for 
(a)

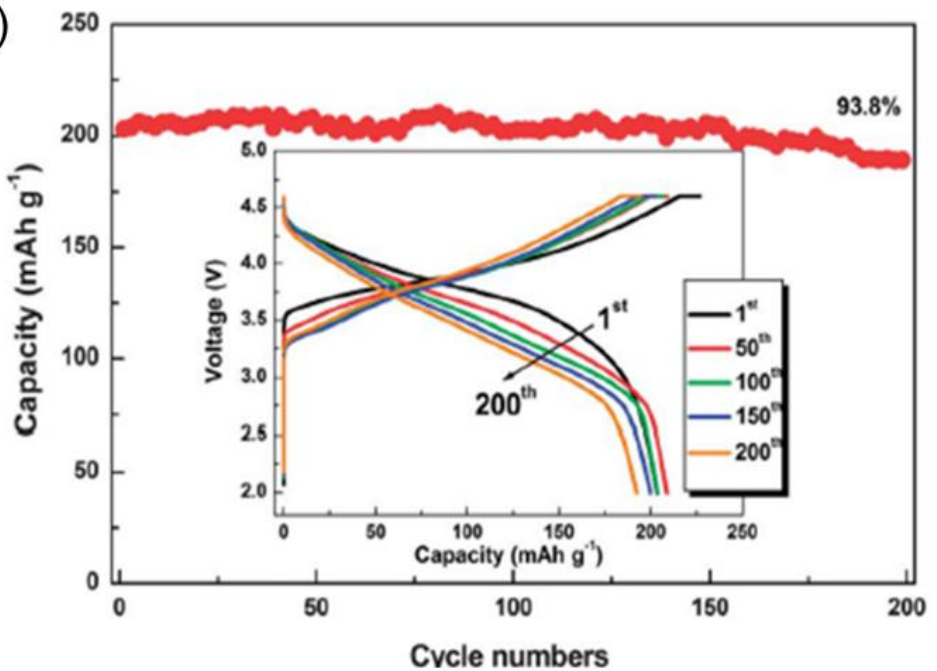

(b)

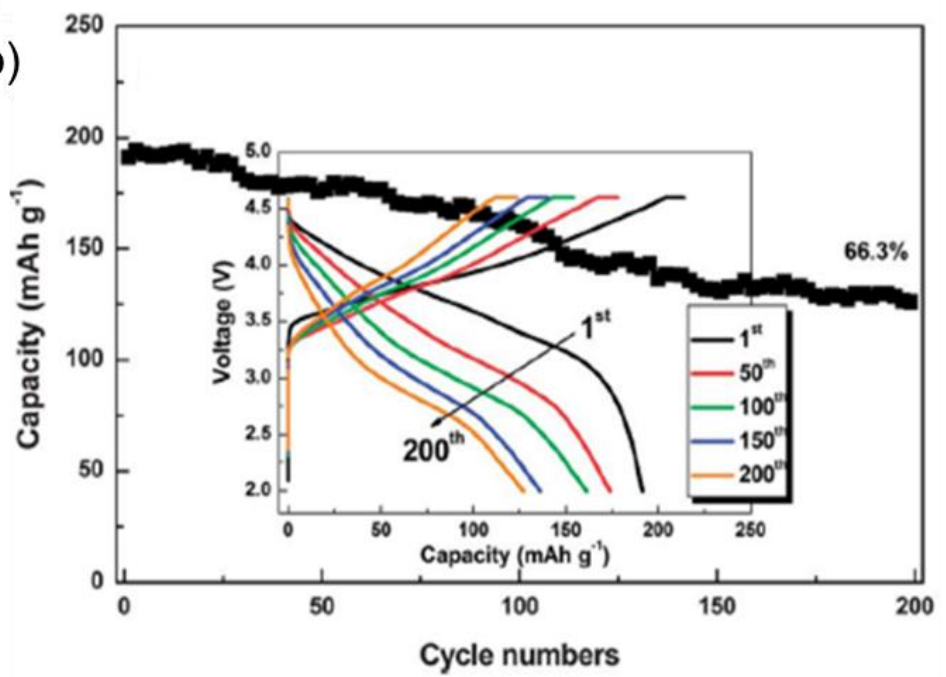

(c) $2 0 0 \longdiv { - 1 0 0 } 1 0 0$

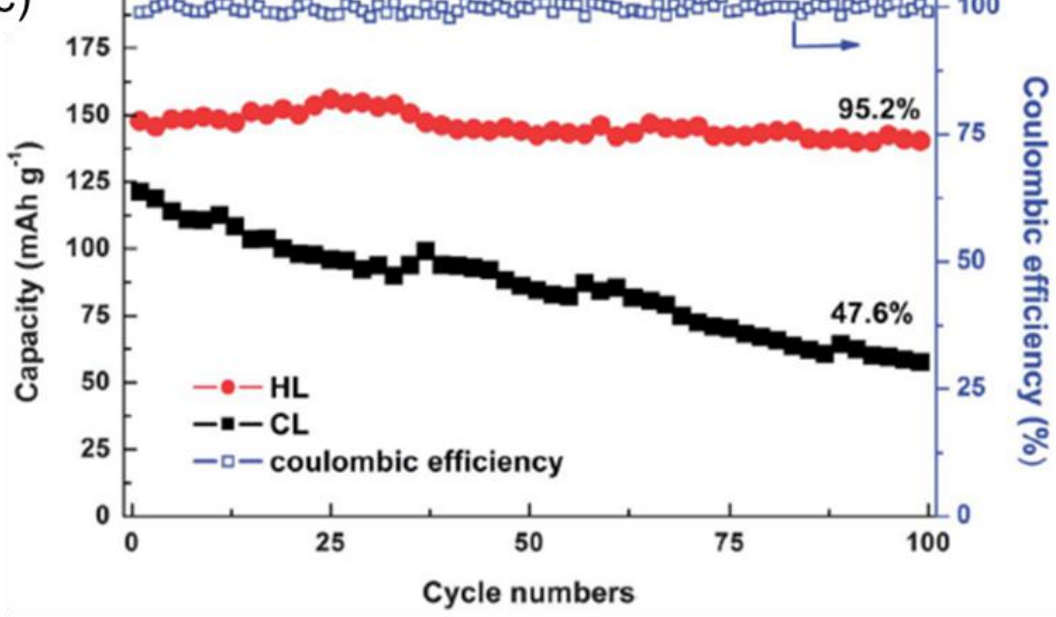

Figure 18: Performances upon cycling of the material $\mathrm{Li}_{1.14} \mathrm{Ni}_{0.25} \mathrm{Mn}_{0.60} \mathrm{Co}_{0.15} \mathrm{O}_{2}$ used as positive electrode in lithium cells. The potential window is $2-4.6 \mathrm{~V}$ and the electrolyte $1 \mathrm{M} \mathrm{LiPF}_{6}$ in a mixture of ethylene and dimethyl carbonates (1:1 in volume). (a) $\mathrm{Li}_{1.14} \mathrm{Ni}_{0.25} \mathrm{Mn}_{0.60} \mathrm{Co}_{0.15} \mathrm{O}_{2}$ is the concentration gradient (CL) characterized in Figure 17 and the cycling rate is $\mathrm{C} / 2$. (b) $\mathrm{Li}_{1.14} \mathrm{Ni}_{0.25} \mathrm{Mn}_{0.60} \mathrm{Co}_{0.15} \mathrm{O}_{2}$ is the corresponding homogeneous material (HL) and the cycling rate is $\mathrm{C} / 2$. (c) the performances of the two materials are compared at a higher rate of 5C (Adapted from the reference [134]). 
the homogenous composition, as if the irreversible loss of oxidized oxygen at the surface of the primary particles was mitigated. That result is unexpected considering the preferential presence of the Mn-richer composition at the surface of the material, except if by engineering this composite the microstructure of the aggregates (porosity, morphology of the primary particles ...) was different enough to minimize this instability.

\section{Conclusions}

The next step appears even much more challenging than that overpass during the last twenty years, to develop successfully the promising Li-rich layered oxides to propose the next generation of higher energy density positive electrode materials for Lithium-ion batteries. Up to now, we were playing with the phase modifying its composition, structure and morphology and we were limited to deliver successfully less than $70 \%$ of the theoretical capacity in most cases (i.e. less than $180 \mathrm{mAh} / \mathrm{g}$ ). Struggling to reach higher reversible capacity means that the chemical and thermal instabilities of layered oxides will be exacerbated, for the layered oxides involving only the transition metal ions into the redox processes, and even more those involving the oxygen anion.

Solutions exist and are prospected, but their developments are challenging as we are moving to material engineering with the preparation of composite materials to stabilize metastable materials at their surface and to create synergies between properties. Coatings, core-shell and concentration gradient complex engineered materials are part of the answer, but preferential growth of oriented surface, controlled porosity and densification of the aggregates ... are another part of the answer. The preparation of these materials is challenging as it requires to control the composition and structure at any stage from the core to the bulk and at the particle and aggregates level. 


\section{References}

[1] A. Van der Ven et G. Ceder, « Lithium diffusion mechanisms in layered intercalation compounds ", J. Power Sources, vol. 97-98, p. 529-531, juill. 2001.

[2] S. Levasseur et al., "Oxygen Vacancies and Intermediate Spin Trivalent Cobalt lons in LithiumOverstoichiometric LiCoO2 », Chem. Mater., vol. 15, n 1, p. 348-354, janv. 2003.

[3] S. Kalluri et al., " Li-lon Cells: Surface Engineering Strategies of Layered LiCoO2 Cathode Material to Realize High-Energy and High-Voltage Li-lon Cells (Adv. Energy Mater. 1/2017) ", Adv. Energy Mater., vol. 7, $\mathrm{n}^{\circ}$ 1, p. n/a-n/a, janv. 2017.

[4] S.-T. Myung, N. Kumagai, S. Komaba, et H.-T. Chung, " Effects of Al doping on the microstructure of LiCoO2 cathode materials ", Solid State Ion., vol. 139, n 1-2, p. 47-56, janv. 2001.

[5] S. Levasseur, M. Ménétrier, et C. Delmas, « On the LixCo1-yMgyO2 system upon deintercalation: electrochemical, electronic properties and 7Li MAS NMR studies ", J. Power Sources, vol. 112, n², p. 419-427, nov. 2002.

[6] S. Verdier, L. El Ouatani, R. Dedryvère, F. Bonhomme, P. Biensan, et D. Gonbeau, « XPS Study on Al2O3- and AlPO4-Coated LiCoO2 Cathode Material for High-Capacity Li lon Batteries ", J. Electrochem. Soc., vol. 154, $\mathrm{n}^{\circ}$ 12, p. A1088, 2007.

[7] Y. S. Jung et al., " Unexpected Improved Performance of ALD Coated LiCoO2/Graphite Li-lon Batteries ", Adv. Energy Mater., vol. 3, n 2, p. 213-219, févr. 2013.

[8] D. Andre et al., " Future generations of cathode materials: an automotive industry perspective ", J. Mater. Chem. A, vol. 3, n 13, p. 6709-6732, mars 2015.

[9] C. Delmas et L. Croguennec, "Layered Li(Ni, M)O2 Systems as the Cathode Material in LithiumIon Batteries ", MRS Bull., vol. 27, $\mathrm{n}^{\circ}$ 08, p. 608-612, août 2002.

[10] J. P. Peres et al., "The relationship between the composition of lithium nickel oxide and the loss of reversibility during the first cycle ", J. Phys. Chem. Solids, vol. 57, n 6, p. 1057-1060, juin 1996.

[11] M. Guilmard, L. Croguennec, et C. Delmas, « Thermal Stability of Lithium Nickel Oxide Derivatives. Part II: LixNi0.70Co0.15Al0.1502 and LixNi0.90Mn0.10O2 ( $x=0.50$ and 0.30). Comparison with LixNi1.02O2 and LixNi0.89Al0.1602 », Chem. Mater., vol. 15, n²3, p. 4484-4493, nov. 2003.

[12] B. Ammundsen et al., "Local Structure and First Cycle Redox Mechanism of Layered Li[sub 1.2] Cr[sub 0.4] Mn[sub 0.4]O[sub 2] Cathode Material », J. Electrochem. Soc., vol. 149, $n^{\circ} 4, p$. A431, 2002.

[13] E. Rossen, C. D. W. Jones, et J. R. Dahn, "Structure and electrochemistry of LixMnyNi1-yO2 », Solid State Ion., vol. 57, n 3, p. 311-318, oct. 1992.

[14] T. Ohzuku et Y. Makimura, "Layered Lithium Insertion Material of LiCo1/3Ni1/3Mn1/3O2 for Lithium-Ion Batteries », Chem. Lett., vol. 30, n 7, p. 642-643, juill. 2001.

[15] T. Ohzuku et Y. Makimura, « Layered Lithium Insertion Material of LiNi1/2Mn1/2O2 : A Possible Alternative to LiCoO2 for Advanced Lithium-Ion Batteries », Chem. Lett., vol. 30, $n^{\circ} 8, \mathrm{p}$. 744-745, août 2001.

[16] H.-J. Noh, S. Youn, C. S. Yoon, et Y.-K. Sun, « Comparison of the structural and electrochemical properties of layered Li[NixCoyMnz]O2 $(x=1 / 3,0.5,0.6,0.7,0.8$ and 0.85$)$ cathode material for lithium-ion batteries ", J. Power Sources, vol. 233, p. 121-130, juill. 2013.

[17] L. Croguennec et M. R. Palacin, « Recent Achievements on Inorganic Electrode Materials for Lithium-Ion Batteries », J. Am. Chem. Soc., vol. 137, n 9, p. 3140-3156, mars 2015.

[18] A. Boulineau, L. Croguennec, C. Delmas, et F. Weill, « Structure of Li2MnO3 with different degrees of defects », Solid State Ion., vol. 180, n 40, p. 1652-1659, janv. 2010. 
[19] D. Pasero, V. McLaren, S. de Souza, et A. R. West, " Oxygen Nonstoichiometry in Li2MnO3: An Alternative Explanation for Its Anomalous Electrochemical Activity ", Chem. Mater., vol. 17, $\mathrm{n}^{\circ}$ 2, p. 345-348, janv. 2005.

[20] A. Boulineau, L. Croguennec, C. Delmas, et F. Weill, « Reinvestigation of Li2MnO3 Structure: Electron Diffraction and High Resolution TEM », Chem. Mater., vol. 21, n 18, p. 4216-4222, sept. 2009.

[21] J. R. Croy, J. S. Park, F. Dogan, C. S. Johnson, B. Key, et M. Balasubramanian, « First-Cycle Evolution of Local Structure in Electrochemically Activated Li2MnO3 », Chem. Mater., vol. 26, $\mathrm{n}^{\circ}$ 24, p. 7091-7098, déc. 2014.

[22] A. D. Robertson et P. G. Bruce, " Mechanism of Electrochemical Activity in Li2MnO3 », Chem. Mater., vol. 15, n 10, p. 1984-1992, mai 2003.

[23] D. Y. W. Yu, K. Yanagida, Y. Kato, et H. Nakamura, " Electrochemical Activities in Li2MnO3 ", J. Electrochem. Soc., vol. 156, n 6, p. A417-A424, janv. 2009.

[24] R. Xiao, H. Li, et L. Chen, "Density Functional Investigation on Li2MnO3 », Chem. Mater., vol. 24, n²1, p. 4242-4251, nov. 2012.

[25] K. A. Jarvis, Z. Deng, L. F. Allard, A. Manthiram, et P. J. Ferreira, " Atomic Structure of a LithiumRich Layered Oxide Material for Lithium-Ion Batteries: Evidence of a Solid Solution », Chem. Mater., vol. 23, n 16, p. 3614-3621, août 2011.

[26] J. Bareño et al., " Long-Range and Local Structure in the Layered Oxide Li1.2Co0.4Mn0.4O2 ", Chem. Mater., vol. 23, $\mathrm{n}^{\circ}$ 8, p. 2039-2050, avr. 2011.

[27] H. Koga et al., " Li1.20Mn0.54Co0.13Ni0.1302 with Different Particle Sizes as Attractive Positive Electrode Materials for Lithium-Ion Batteries: Insights into Their Structure », J. Phys. Chem. C, vol. 116, n²5, p. 13497-13506, juin 2012.

[28] E. McCalla, A. W. Rowe, R. Shunmugasundaram, et J. R. Dahn, " Structural Study of the Li-Mn$\mathrm{Ni}$ Oxide Pseudoternary System of Interest for Positive Electrodes of Li-lon Batteries ॥, Chem. Mater., vol. 25, n 6, p. 989-999, mars 2013.

[29] E. McCalla, A. W. Rowe, C. R. Brown, L. R. P. Hacquebard, et J. R. Dahn, « How Phase Transformations during Cooling Affect Li-Mn-Ni-O Positive Electrodes in Lithium Ion Batteries ", J. Electrochem. Soc., vol. 160, nº 8, p. A1134-A1138, janv. 2013.

[30] E. McCalla, C. M. Lowartz, C. R. Brown, et J. R. Dahn, « Formation of Layered-Layered Composites in the Li-Co-Mn Oxide Pseudoternary System during Slow Cooling ", Chem. Mater., vol. 25, n 6, p. 912-918, mars 2013.

[31] E. McCalla, J. Li, A. W. Rowe, et J. R. Dahn, « The Negative Impact of Layered-Layered Composites on the Electrochemistry of Li-Mn-Ni-O Positive Electrodes for Lithium-Ion Batteries ", J. Electrochem. Soc., vol. 161, n 4, p. A606-A613, janv. 2014.

[32] B. R. Long et al., " Effect of Cooling Rates on Phase Separation in 0.5Li2MnO3.0.5LiCoO2 Electrode Materials for Li-Ion Batteries », Chem. Mater., vol. 26, n 11, p. 3565-3572, juin 2014.

[33] M. M. Thackeray, S.-H. Kang, C. S. Johnson, J. T. Vaughey, R. Benedek, et S. A. Hackney, "Li2MnO3-stabilized LiMO2 ( $\mathrm{M}=\mathrm{Mn}, \mathrm{Ni}, \mathrm{Co}$ ) electrodes for lithium-ion batteries ", J. Mater. Chem., vol. 17, $n^{\circ}$ 30, p. 3112-3125, août 2007.

[34] Z. Lu et J. R. Dahn, « Understanding the Anomalous Capacity of $\mathrm{Li} / \mathrm{Li}[\mathrm{NixLi}(1 / 3-2 \mathrm{x} / 3) \mathrm{Mn}(2 / 3-\mathrm{x} / 3) \mathrm{O} 2$ Cells Using In Situ X-Ray Diffraction and Electrochemical Studies ", J. Electrochem. Soc., vol. 149, $n^{\circ}$ 7, p. A815, 2002.

[35] F. Weill, N. Tran, L. Croguennec, et C. Delmas, « Cation ordering in the layered Li1+x(Ni0.425Mn0.425Co0.15)1-xO2 materials ( $\mathrm{x}=0$ and 0.12) ", J. Power Sources, vol. 172, $\mathrm{n}^{\circ} 2$, p. 893-900, oct. 2007.

[36] H. Koga et al., " Li1,20Mn0.54Co0.13Ni0.1302 with Different Particle Sizes as Attractive Positive Electrode Materials for Lithium-Ion Batteries : Insights into Their Structure », J. Phys. Chem. C, vol. 116, p. 13497-13503, 2012.

[37] J. Cabana et al., "Structural complexity of layered-spinel composite electrodes for Li-ion batteries ", J. Mater. Res., vol. 25, nº8, p. 1601-1616, août 2010. 
[38] R. Armstrong et al., " Demonstrating Oxygen Loss and Associated Structural Reorganization in the Lithium Battery Cathode Li(Ni0,2Li0,2Mn0,6)O2 », Journal of American Chemical Society, p. 8694-8698, 2006.

[39] H. Koga, L. Croguennec, M. Ménétrier, P. Mannessiez, F. Weill, et C. Delmas, « Different oxygen redox participation for bulk and surface: A possible global explanation for the cycling mechanism of Li1.20Mn0.54Co0.13Ni0.13O2 », J. Power Sources, vol. 236, p. 250-258, août 2013

[40] H. Koga et al., " Reversible Oxygen Participation to the Redox Processes Revealed for Li1.20Mn0.54Co0.13Ni0.1302 », J. Electrochem. Soc., vol. 160, nº 6, p. A786-A792, mars 2013.

[41] H. Koga et al., "Operando X-ray Absorption Study of the Redox Processes Involved upon Cycling of the Li-Rich Layered Oxide $\mathrm{Li}_{1.20} \mathrm{Mn}_{0.54} \mathrm{Co}_{0.13} \mathrm{Ni}_{0.13} \mathrm{O}_{2}$ in Li lon Batteries ", J. Phys. Chem. C, vol. 118, n 11, p. 5700-5709, mars 2014.

[42] M. Oishi et al., " Direct observation of reversible charge compensation by oxygen ion in Li-rich manganese layered oxide positive electrode material, Li1.16Ni0.15Co0.19Mn0.50O2 », J. Power Sources, vol. 276, p. 89-94, févr. 2015.

[43] B. Xu, C. R. Fell, M. Chi, et Y. S. Meng, "Identifying surface structural changes in layered Liexcess nickel manganese oxides in high voltage lithium ion batteries: $\mathrm{A}$ joint experimental and theoretical study ", Energy Environ. Sci., vol. 4, nº 6, p. 2223-2233, juin 2011.

[44] D. Qian, B. Xu, M. Chi, et Y. S. Meng, "Uncovering the roles of oxygen vacancies in cation migration in lithium excess layered oxides ", Phys. Chem. Chem. Phys., vol. 16, $n^{\circ} 28$, p. 14665-14668, juin 2014.

[45] C. Genevois, H. Koga, L. Croguennec, M. Ménétrier, C. Delmas, et F. Weill, « Insight into the Atomic Structure of Cycled Lithium-Rich Layered Oxide Li1.20Mn0.54Co0.13Ni0.1302 Using HAADF STEM and Electron Nanodiffraction ", J. Phys. Chem. C, vol. 119, n 1, p. 75-83, janv. 2015.

[46] A. Boulineau, L. Simonin, J. Colin, C. Bourbon, et S. Patoux, « First Evidence of ManganeseNickel Segregation and Densification upon Cycling in Li-Rich Layered Oxides for Lithium Batteries ", Nano Lett., vol. 13, p. 3857-3863, 2013.

[47] A. Boulineau, L. Simonin, J.-F. Colin, E. Canévet, L. Daniel, et S. Patoux, « Evolutions of Li ${ }_{1.2} \mathrm{Mn}$ $0.61 \mathrm{Ni}_{0.18} \mathrm{Mg}_{0.01} \mathrm{O}_{2}$ during the Initial Charge/Discharge Cycle Studied by Advanced Electron Microscopy ", Chem. Mater., vol. 24, nº 18, p. 3558-3566, sept. 2012.

[48] B. Strehle et al., "The Role of Oxygen Release from Li- and Mn-Rich Layered Oxides during the First Cycles Investigated by On-Line Electrochemical Mass Spectrometry ", J. Electrochem. Soc., vol. 164, n² 2, p. A400-A406, janv. 2017.

[49] J. R. Croy, D. Kim, M. Balasubramanian, K. Gallagher, S.-H. Kang, et M. M. Thackeray, " Countering the Voltage Decay in High Capacity xLi2MnO3•(1-x)LiMO2 Electrodes ( M=Mn, Ni, Co) for Li+-Ion Batteries », J. Electrochem. Soc., vol. 159, n 6, p. A781-A790, janv. 2012.

[50] J. R. Croy et al., " Examining Hysteresis in Composite xLi2MnO3·(1-x)LiMO2 Cathode Structures », J. Phys. Chem. C, vol. 117, n 13, p. 6525-6536, avr. 2013.

[51] J. R. Croy, K. G. Gallagher, M. Balasubramanian, B. R. Long, et M. M. Thackeray, "Quantifying Hysteresis and Voltage Fade in xLi2MnO3bullet(1-x)LiMn0.5Ni0.5O2 Electrodes as a Function of Li2MnO3 Content ", J. Electrochem. Soc., vol. 161, n 3, p. A318-A325, déc. 2013.

[52] D. Peralta et al., " Role of the composition of lithium-rich layered oxide materials on the voltage decay ", J. Power Sources, vol. 280, p. 687-694, 2015.

[53] D. Mohanty et al., " Unraveling the Voltage-Fade Mechanism in High-Energy-Density LithiumIon Batteries: Origin of the Tetrahedral Cations for Spinel Conversion », Chem. Mater., vol. 26, $n^{\circ} 21$, p. 6272-6280, nov. 2014

[54] F. Dogan et al., "Re-entrant Lithium Local Environments and Defect Driven Electrochemistry of Li- and Mn-Rich Li-Ion Battery Cathodes ", J. Am. Chem. Soc., vol. 137, n 6, p. 2328-2335, févr. 2015. 
[55] J. Li, R. Shunmugasundaram, R. Doig, et J. R. Dahn, « In Situ X-ray Diffraction Study of Layered Li-Ni-Mn-Co Oxides: Effect of Particle Size and Structural Stability of Core-Shell Materials », Chem. Mater., vol. 28, $n^{\circ}$ 1, p. 162-171, janv. 2016.

[56] P. Oh et al., « Superior Long-Term Energy Retention and Volumetric Energy Density for Li-Rich Cathode Materials », Nano Lett., vol. 14, n 10, p. 5965-5972, oct. 2014.

[57] M. Sathiya et al., "Origin of voltage decay in high-capacity layered oxide electrodes ", Nat. Mater., vol. 14, $n^{\circ}$ 2, p. 230-238, déc. 2014.

[58] J. Zheng et al., "Mitigating Voltage Fade in Cathode Materials by Improving the Atomic Level Uniformity of Elemental Distribution », Nano Lett., vol. 14, n 5, p. 2628-2635, mai 2014.

[59] M. Sathiya et al., " High Performance $\mathrm{Li}_{2} \mathrm{Ru}_{1-y} \mathrm{Mn}_{y} \mathrm{O}_{3}(0.2 \leq y \leq 0.8)$ Cathode Materials for Rechargeable Lithium-Ion Batteries: Their Understanding ", Chem. Mater., vol. 25, n 7, p. 1121-1131, avr. 2013.

[60] A. R. Armstrong et P. G. Bruce, « Synthesis of layered LiMnO2 as an electrode for rechargeable lithium batteries ", Nature, vol. 381, n 6582, p. 499-500, juin 1996.

[61] F. Capitaine, P. Gravereau, et C. Delmas, " A new variety of LiMnO2 with a layered structure ", Solid State lon., vol. 89, nº 3, p. 197-202, août 1996.

[62] L. Croguennec, P. Deniard, et R. Brec, « Electrochemical Cyclability of Orthorhombic LiMnO2 Characterization of Cycled Materials ", J. Electrochem. Soc., vol. 144, $n^{\circ} 10$, p. 3323-3330, janv. 1997.

[63] L. Simonin et al., " In situ investigations of a Li-rich Mn-Ni layered oxide for Li-ion batteries ", J. Mater. Chem., vol. 22, n 22, p. 11316, 2012.

[64] N. Yabuuchi, K. Yoshii, S.-T. Myung, I. Nakai, et S. Komaba, " Detailed Studies of a High-Capacity Electrode Material for Rechargeable Batteries, $\mathrm{Li}_{2} \mathrm{MnO}_{3}-\mathrm{LiCo}_{1 / 3} \mathrm{Ni}_{1 / 3} \mathrm{Mn}_{1 / 3} \mathrm{O}_{2}$ ", J. Am. Chem. Soc., vol. 133, $n^{\circ} 12$, p. 4404-4419, mars 2011.

[65] M. Bettge et al., « Improving high-capacity Li1.2Ni0.15Mn0.55Co0.1O2-based lithium-ion cells by modifiying the positive electrode with alumina », J. Power Sources, vol. 233, p. 346-357, juill. 2013.

[66] M. Sathiya et al., « Reversible anionic redox chemistry in high-capacity layered-oxide electrodes ", Nat. Mater., vol. 12, nº 9, p. 827-835, juill. 2013.

[67] M. Sathiya et al., "Origin of voltage decay in high-capacity layered oxide electrodes ", Nat. Mater., vol. 14, n² 2, p. 230-238, déc. 2014.

[68] Y. Xie, M. Saubanère, et M.-L. Doublet, « Requirements for reversible extra-capacity in Li-rich layered oxides for Li-ion batteries », Energy Environ. Sci., vol. 10, n 1, p. 266-274, janv. 2017.

[69] K. Luo et al., "Charge-compensation in 3d-transition-metal-oxide intercalation cathodes through the generation of localized electron holes on oxygen ", Nat. Chem., vol. 8, n ${ }^{\circ}$, p. 684-691, mars 2016.

[70] D.-H. Seo, J. Lee, A. Urban, R. Malik, S. Kang, et G. Ceder, " The structural and chemical origin of the oxygen redox activity in layered and cation-disordered Li-excess cathode materials ", Nat. Chem., vol. 8, $n^{\circ}$ 7, p. 692-697, mai 2016.

[71] C. Delmas, « Battery materials: Operating through oxygen ", Nat. Chem., vol. 8, n 7, p. 641-643, juin 2016.

[72] J. Lee, A. Urban, X. Li, D. Su, G. Hautier, et G. Ceder, « Unlocking the Potential of CationDisordered Oxides for Rechargeable Lithium Batteries ", Science, vol. 343, n 6170, p. 519-522, janv. 2014.

[73] R. Chen et al., " $\mathrm{Li}^{+}$intercalation in isostructural $\mathrm{Li}_{2} \mathrm{VO}_{3}$ and $\mathrm{Li}_{2} \mathrm{VO}_{2} \mathrm{~F}_{\text {with }} \mathrm{O}^{2-}$ and mixed $\mathrm{O}^{2-}$ /F ${ }^{-}$anions ", Phys Chem Chem Phys, vol. 17, n 26, p. 17288-17295, 2015.

[74] R. Wang et al., " A disordered rock-salt Li-excess cathode material with high capacity and substantial oxygen redox activity: Li1.25Nb0.25Mn0.5O2 », Electrochem. Commun., vol. 60, p. 70-73, nov. 2015. 
[75] N. Yabuuchi, M. Takeuchi, S. Komaba, S. Ichikawa, T. Ozaki, et T. Inamasu, « Synthesis and electrochemical properties of $\mathrm{Li}_{1.3} \mathrm{Nb}_{0.3} \mathrm{~V}_{0.4} \mathrm{O}_{2}$ as a positive electrode material for rechargeable lithium batteries ", Chem Commun, vol. 52, n 10, p. 2051-2054, 2016.

[76] N. Yabuuchi et al., " Origin of stabilization and destabilization in solid-state redox reaction of oxide ions for lithium-ion batteries ", Nat. Commun., vol. 7, p. 13814, déc. 2016.

[77] N. Yabuuchi, Y. Tahara, S. Komaba, S. Kitada, et Y. Kajiya, « Synthesis and Electrochemical Properties of $\mathrm{Li}_{4} \mathrm{MoO}_{5}-\mathrm{NiO}$ Binary System as Positive Electrode Materials for Rechargeable Lithium Batteries ", Chem. Mater., vol. 28, n² 2, p. 416-419, janv. 2016.

[78] P. E. Pearce et al., "Evidence for anionic redox activity in a tridimensional-ordered Li-rich positive electrode $\beta$-Li2IrO3 ", Nat. Mater., vol. 16, n 5, p. 580-586, févr. 2017.

[79] M. Freire et al., "A new active Li-Mn-O compound for high energy density Li-ion batteries", Nat. Mater., vol. 15, n 2, p. 173-177, nov. 2015.

[80] J. W. Fergus, " Recent developments in cathode materials for lithium ion batteries ", J. Power Sources, vol. 195, n² 4, p. 939-954, févr. 2010.

[81] P. Albertus, J. Christensen, et J. Newman, « Experiments on and Modeling of Positive Electrodes with Multiple Active Materials for Lithium-Ion Batteries ", J. Electrochem. Soc., vol. 156, $n^{\circ}$ 7, p. A606, 2009.

[82] A. Manthiram et W. Choi, « Suppression of Mn Dissolution in Spinel Cathodes by Trapping the Protons within Layered Oxide Cathodes ", Electrochem. Solid-State Lett., vol. 10, n 9, p. A228, 2007.

[83] K.-W. Nam, W.-S. Yoon, H. Shin, K. Y. Chung, S. Choi, et X.-Q. Yang, "In situ X-ray diffraction studies of mixed LiMn2O4-LiNi1/3Co1/3Mn1/3O2 composite cathode in Li-ion cells during charge-discharge cycling ", J. Power Sources, vol. 192, n² 2, p. 652-659, juill. 2009.

[84] T. Numata, C. Amemiya, T. Kumeuchi, M. Shirakata, et M. Yonezawa, « Advantages of blending LiNi0.8Co0.2O2 into Li1+xMn2-xO4 cathodes ", J. Power Sources, vol. 97-98, p. 358-360, juill. 2001.

[85] K. G. Gallagher, S.-H. Kang, S. U. Park, et S. Y. Han, « xLi2MnO3·(1-x)LiMO2 blended with LiFePO4 to achieve high energy density and pulse power capability ", J. Power Sources, vol. 196, $n^{\circ} 22$, p. 9702-9707, nov. 2011.

[86] N. Imachi, Y. Takano, H. Fujimoto, Y. Kida, et S. Fujitani, « Layered Cathode for Improving Safety of Li-Ion Batteries », J. Electrochem. Soc., vol. 154, n 5, p. A412, 2007.

[87] J. F. Whitacre, K. Zaghib, W. C. West, et B. V. Ratnakumar, « Dual active material composite cathode structures for Li-ion batteries ", J. Power Sources, vol. 177, $n^{\circ} 2$, p. 528-536, mars 2008.

[88] $\mathrm{H}$. Liu et al., " Understanding the Role of $\mathrm{NH}_{4} \mathrm{~F}$ and $\mathrm{Al}_{2} \mathrm{O}_{3}$ Surface Co-modification on LithiumExcess Layered Oxide $\mathrm{Li}_{1.2} \mathrm{Ni}_{0.2} \mathrm{Mn}_{0.6} \mathrm{O}_{2}$ ", ACS Appl. Mater. Interfaces, vol. 7, $\mathrm{n}^{\circ}$ 34, $\mathrm{p}$. 19189-19200, sept. 2015.

[89] K. Araki, N. Taguchi, H. Sakaebe, K. Tatsumi, et Z. Ogumi, « Electrochemical properties of LiNi1/3Co1/3Mn1/3O2 cathode material modified by coating with Al2O3 nanoparticles ", J. Power Sources, vol. 269, p. 236-243, déc. 2014.

[90] G. Kobayashi et al., " Improving cycling performance of Li-rich layered cathode materials through combination of Al2O3-based surface modification and stepwise precycling ", J. Power Sources, vol. 303, p. 250-256, janv. 2016.

[91] B. Li, Y. Yu, et J. Zhao, « Facile synthesis of spherical xLi2MnO3.(1-x)Li(Mn0.33Co0.33Ni0.33)O2 as cathode materials for lithium-ion batteries with improved electrochemical performance $", J$. Power Sources, vol. 275, p. 64-72, févr. 2015.

[92] S. J. Shi et al., " Enhanced cycling stability of Li[Li0.2Mn0.54Ni0.13Co0.13]O2 by surface modification of $\mathrm{MgO}$ with melting impregnation method ", Electrochimica Acta, vol. 88, p. 671-679, janv. 2013.

[93] Y. Liu et al., " Improved electrochemical performance of Li1.2Ni0.2Mn0.6O2 cathode material with fast ionic conductor Li3VO4 coating ", lonics, vol. 21, n 10, p. 2725-2733, oct. 2015. 
[94] Z. Wang et al., " Cycle performance improvement of Li-rich layered cathode material Li[Li0.2Mn0.54Ni0.13Co0.13]O2 by ZrO2 coating ", Surf. Coat. Technol., vol. 235, p. 570-576, nov. 2013.

[95] Y. Huang, J. Chen, J. Ni, H. Zhou, et X. Zhang, " A modified ZrO2-coating process to improve electrochemical performance of $\mathrm{Li}(\mathrm{Ni} 1 / 3 \mathrm{Co} 1 / 3 \mathrm{Mn} 1 / 3) \mathrm{O} 2$ ", J. Power Sources, vol. 188, $\mathrm{n}^{\circ} 2$, p. 538-545, mars 2009.

[96] X. Liu, J. Liu, T. Huang, et A. Yu, « CaF2-coated Li1.2Mn0.54Ni0.13Co0.13O2 as cathode materials for Li-ion batteries ", Electrochimica Acta, vol. 109, p. 52-58, oct. 2013.

[97] J. Camardese, D. W. Abarbanel, E. McCalla, et J. R. Dahn, « Synthesis of Spherical Core-Shell $\mathrm{Ni}(\mathrm{OH}) 2-\mathrm{Ni1} / 2 \mathrm{Mn} 1 / 2(\mathrm{OH}) 2$ Particles via a Continuously Stirred Tank Reactor », J. Electrochem. Soc., vol. 161, n 6, p. A890-A895, avr. 2014.

[98] J. Li, J. Camardese, R. Shunmugasundaram, S. Glazier, Z. Lu, et J. R. Dahn, " Synthesis and Characterization of the Lithium-Rich Core-Shell Cathodes with Low Irreversible Capacity and Mitigated Voltage Fade ", Chem. Mater., vol. 27, nº 9, p. 3366-3377, mai 2015.

[99] J. Camardese, J. Li, D. W. Abarbanel, A. T. B. Wright, et J. R. Dahn, « The Effect of Lithium Content and Core to Shell Ratio on Structure and Electrochemical Performance of Core-Shell $\mathrm{Li}(1+\mathrm{x})[\mathrm{NiO} .6 \mathrm{Mn0.4}](1-\mathrm{x}) \mathrm{O} 2 \mathrm{Li}(1+\mathrm{y})[\mathrm{Ni0} 0.2 \mathrm{Mn0.8}](1-\mathrm{y}) \mathrm{O} 2$ Positive Electrode Materials », J. Electrochem. Soc., vol. 162, $\mathrm{n}^{\circ}$ 3, p. A269-A277, déc. 2014.

[100] H. Shi et al., " Core-shell structured Li[(NiO.8Co0.1Mn0.1)0.7(Ni0.45Co0.1Mn0.45)0.3]O2 cathode material for high-energy lithium ion batteries ", J. Alloys Compd., vol. 587, p. 710-716, févr. 2014.

[101] Y.-K. Sun, S.-T. Myung, H.-S. Shin, Y. C. Bae, et C. S. Yoon, « Novel Core-Shell-Structured Li[( $\mathrm{Ni}_{0.8}$ $\left.\mathrm{Co}_{0.2}\right)_{0.8}\left(\mathrm{Ni}_{0.5} \mathrm{Mn}_{0.5}\right)_{0.2} \mathrm{JO}_{2}$ via Coprecipitation as Positive Electrode Material for Lithium Secondary Batteries ", J. Phys. Chem. B, vol. 110, n 13, p. 6810-6815, avr. 2006.

[102] Y.-K. Sun, S.-T. Myung, B.-C. Park, et K. Amine, "Synthesis of Spherical Nano- to Microscale Core-Shell Particles Li[( $\left.\left.\mathrm{Ni}_{0.8} \mathrm{Co}_{0.1} \mathrm{Mn}_{0.1}\right)_{1-x}\left(\mathrm{Ni}_{0.5} \mathrm{Mn}_{0.5}\right)_{x}\right]_{\mathrm{O}_{2}}$ and Their Applications to Lithium Batteries », Chem. Mater., vol. 18, n²2, p. 5159-5163, oct. 2006.

[103] Y.-K. Sun, S.-T. Myung, B.-C. Park, J. Prakash, I. Belharouak, et K. Amine, " High-energy cathode material for long-life and safe lithium batteries ", Nat. Mater., vol. 8, $n^{\circ} 4$, p. 320-324, avr. 2009.

[104] Y.-K. Sun et al., " Nanostructured high-energy cathode materials for advanced lithium batteries ", Nat. Mater., vol. 11, n 11, p. 942-947, oct. 2012.

[105] Y.-K. Sun, D.-H. Kim, C. S. Yoon, S.-T. Myung, J. Prakash, et K. Amine, « A Novel Cathode Material with a Concentration-Gradient for High-Energy and Safe Lithium-Ion Batteries ", Adv. Funct. Mater., vol. 20, n⿳⺈ 3, p. 485-491, févr. 2010.

[106] Y.-K. Sun, D.-H. Kim, H.-G. Jung, S.-T. Myung, et K. Amine, " High-voltage performance of concentration-gradient $\mathrm{Li}[\mathrm{Ni0} .67 \mathrm{Co} .15 \mathrm{Mn} 0.18] \mathrm{O} 2$ cathode material for lithium-ion batteries ", Electrochimica Acta, vol. 55, $\mathrm{n}^{\circ}$ 28, p. 8621-8627, déc. 2010.

[107] Y.-K. Sun, B.-R. Lee, H.-J. Noh, H. Wu, S.-T. Myung, et K. Amine, «A novel concentration-

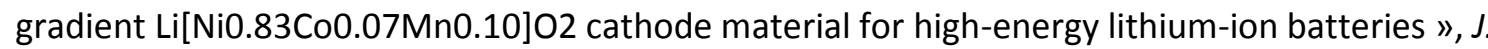
Mater. Chem., vol. 21, ${ }^{\circ} 27$, p. 10108, 2011.

[108] H.-J. Noh, J.-W. Ju, et Y.-K. Sun, « Comparison of Nanorod-Structured LiNi0.54Co0.16Mn0.3002 with Conventional Cathode Materials For Li-Ion Batteries », ChemSusChem, vol. 7, p. 245-252, 2014

[109] J.-W. Ju, E.-J. Lee, C. S. Yoon, S.-T. Myung, et Y.-K. Sun, « Optimization of Layered Cathode Material with Full Concentration Gradient for Lithium-Ion Batteries », J. Phys. Chem. C, vol. 118, $n^{\circ} 1$, p. 175-182, janv. 2014.

[110] S.-J. Yoon, S.-T. Myung, H.-J. Noh, J. Lu, K. Amine, et Y.-K. Sun, « Nanorod and Nanoparticle Shells in Concentration Gradient Core-Shell Lithium Oxides for Rechargeable Lithium Batteries ", ChemSusChem, vol. 7, n 12, p. 3295-3303, déc. 2014. 
[111] S.-J. Yoon, K.-J. Park, B.-B. Lim, C. S. Yoon, et Y.-K. Sun, « Improved Performances of Li[NiO. 65Co0. 08Mn0. 27]O2 Cathode Material with Full Concentration Gradient for Li-Ion Batteries », J. Electrochem. Soc., vol. 162, n 2, p. A3059-A3063, 2015.

[112] E.-J. Lee, H.-J. Noh, C. S. Yoon, et Y.-K. Sun, « Effect of outer layer thickness on full concentration gradient layered cathode material for lithium-ion batteries », J. Power Sources, vol. 273, p. 663-669, janv. 2015.

[113] Y. Li et al., "Synthesis of full concentration gradient cathode studied by high energy X-ray diffraction ", Nano Energy, vol. 19, p. 522-531, janv. 2016.

[114] B.-B. Lim et al., " Advanced Concentration Gradient Cathode Material with Two-Slope for HighEnergy and Safe Lithium Batteries ", Adv. Funct. Mater., vol. 25, n² 29, p. 4673-4680, août 2015.

[115] K.-J. Park et al., " A high-capacity Li[Ni0.8Co0.06Mn0.14]O2 positive electrode with a dual concentration gradient for next-generation lithium-ion batteries ", J Mater Chem A, vol. 3, $\mathrm{n}^{\circ}$ 44, p. 22183-22190, 2015.

[116] Z. Huang, J. Gao, X. He, J. Li, et C. Jiang, « Well-ordered spherical LiNixCo(1-2x)MnxO2 cathode materials synthesized from cobolt concentration-gradient precursors », J. Power Sources, vol. 202, p. 284-290, mars 2012.

[117] K. Du, C. Hua, C. Tan, Z. Peng, Y. Cao, et G. Hu, « A high-powered concentration-gradient $\mathrm{Li}(\mathrm{NiO} .85 \mathrm{Co} .12 \mathrm{Mn} 0.03) \mathrm{O} 2$ cathode material for lithium ion batteries ", J. Power Sources, vol. 263, p. 203-208, oct. 2014.

[118] C. Hua, K. Du, C. Tan, Z. Peng, Y. Cao, et G. Hu, " Study of full concentration-gradient

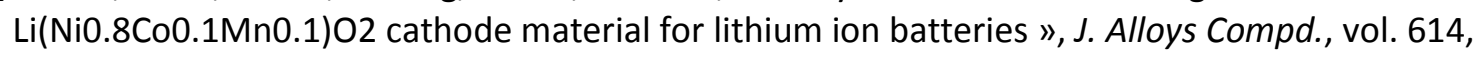
p. 264-270, nov. 2014

[119] L.-W. Liang, K. Du, Z.-D. Peng, Y.-B. Cao, et G.-R. Hu, « Synthesis and electrochemical performance of LiNi0.6Co0.2Mn0.2O2 as a concentration-gradient cathode material for lithium batteries ", Chin. Chem. Lett., vol. 25, n 6, p. 883-886, juin 2014.

[120] L. Liang, G. Hu, Y. Cao, K. Du, et Z. Peng, " Synthesis and characterization of full concentrationgradient LiNi0.7Co0.1Mn0.2O2 cathode material for lithium-ion batteries », J. Alloys Compd., vol. 635, p. 92-100, juin 2015.

[121] P. Y. Hou, L. Q. Zhang, et X. P. Gao, « A high-energy, full concentration-gradient cathode material with excellent cycle and thermal stability for lithium ion batteries ", J Mater Chem A, vol. 2, nº 40, p. 17130-17138, août 2014.

[122] P. Hou et al., " A novel core-concentration gradient-shelled LiNi0.5Co0.2Mn0.3O2 as highperformance cathode for lithium-ion batteries », RSC Adv., vol. 4, $\mathrm{n}^{\circ}$ 31, p. 15923, mars 2014.

[123] D. Song, P. Hou, X. Wang, X. Shi, et L. Zhang, « Understanding the Origin of Enhanced Performances in Core-Shell and Concentration-Gradient Layered Oxide Cathode Materials ", ACS Appl. Mater. Interfaces, vol. 7, n²3, p. 12864-12872, juin 2015.

[124] J.-Y. Liao et A. Manthiram, " Surface-modified concentration-gradient Ni-rich layered oxide cathodes for high-energy lithium-ion batteries ", J. Power Sources, vol. 282, p. 429-436, mai 2015.

[125] J. Wang et al., « Al2O3 Coated Concentration-Gradient Li[Ni0.73Co0.12Mn0.15]O2 Cathode Material by Freeze Drying for Long-Life Lithium Ion Batteries ", Electrochimica Acta, vol. 174, p. 1185-1191, août 2015.

[126] Y.-K. Sun et B.-C. Park, Positive active material comprising a continuous concentration gradient of a metal composition for lithium battery, method of preparing the same, and lithium battery including the same. Google Patents, 2014.

[127] H. J. N. Yang-Kook Sun, « Anode active material with whole particle concentration gradient for lithium secondary battery, method for preparing same, and lithium secondary battery having same », 2014. 
[128] H. J. N. Yang-Kook Sun, " Cathode active material with whole particule concentration gradient for lithium secondary battery, method for preparing the same, and lithium secondary battery having the same ", 06-janv-2015.

[129] Y.-K. Sun, Method of preparing cathode active material precursor for lithium rechargeable battery, cathode active material precursor for lithium rechargeable battery prepared thereby, and cathode active material formed using the cathode active material precursor. Google Patents, 2013.

[130] J.-R. Yu et M.-H. Choi, Method for preparing positive electrode active material precursor and positive electrode material for lithium secondary battery having concentration-gradient layer using batch reactor, and positive electrode active material precursor and positive electrode material for lithium secondary battery prepared by the method. Google Patents, 2011.

[131] D. Hwang, J. Lim, et K. Han, LITHIUM SECONDARY BATTERY. 2015.

[132] G. M. Koenig, I. Belharouak, H. Deng, Y.-K. Sun, et K. Amine, " Composition-Tailored Synthesis of Gradient Transition Metal Precursor Particles for Lithium-Ion Battery Cathode Materials », Chem. Mater., vol. 23, nº 7, p. 1954-1963, avr. 2011.

[133] X. Yang et al., « Spherical lithium-rich layered Li1.13[Mn0.534Ni0.233Co0.233]0.87O2 with concentration-gradient outer layer as high-performance cathodes for lithium ion batteries ", J. Power Sources, vol. 232, p. 338-347, juin 2013.

[134] X. Yang et al., " Suppressed capacity/voltage fading of high-capacity lithium-rich layered materials via the design of heterogeneous distribution in the composition ", J. Mater. Chem. A, vol. 2, n 11, p. 3899, 2014.

[135] R. Yu et al., " Design and Preparation of a Lithium-rich Layered Oxide Cathode with a MgConcentration-Gradient Shell for Improved Rate Capability », ChemElectroChem, vol. 2, $n^{\circ}$ 9, p. 1346-1354, sept. 2015.

[136] S.-T. Myung, H.-J. Noh, S.-J. Yoon, E.-J. Lee, et Y.-K. Sun, « Progress in High-Capacity Core-Shell Cathode Materials for Rechargeable Lithium Batteries ", J. Phys. Chem. Lett., vol. 5, nº 4, p. 671-679, févr. 2014.

[137] J. Li, R. Doig, J. Camardese, K. Plucknett, et J. R. Dahn, « Measurements of Interdiffusion Coefficients of Transition Metals in Layered Li-Ni-Mn-Co Oxide Core-Shell Materials during Sintering ", Chem. Mater., vol. 27, n² 22, p. 7765-7773, nov. 2015. 